\title{
Revised phylogenetic analysis of the Aetosauria (Archosauria: Pseudosuchia); assessing the effects of incongruent morphological character sets
}

William G Parker

Aetosauria is an early-diverging clade of pseudosuchians (crocodile-line archosaurs) that had a global distribution and high species diversity as a key component of various Late Triassic terrestrial faunas. It is one of only two Late Triassic clades of large herbivorous archosaurs, and thus served a critical ecological role. Nonetheless, aetosaur phylogenetic relationships are still poorly understood, owing to an overreliance on osteoderm characters, which are often poorly constructed and suspected to be highly homoplastic. A new phylogenetic analysis of the Aetosauria, comprising 27 taxa and 83 characters, includes more than 40 new characters that focus on better sampling the cranial and endoskeletal regions, and represents the most comprenhensive phylogeny of the clade to date. Parsimony analysis recovered three most parsimonious trees; the strict consensus of these trees finds an Aetosauria that is divided into two main clades: Desmatosuchia, which includes the Desmatosuchinae and the Stagonolepidinae, and Aetosaurinae, which includes the Typothoracinae. As defined Desmatosuchinae now contains Neoaetosauroides engaeus and several taxa that were previously referred to the genus Stagonolepis, and a new clade, Desmatosuchini, is erected for taxa more closely related to Desmatosuchus. Overall support for some clades is still weak, and Partitioned Branch Support (PBS) is applied for the first time to a strictly morphological dataset demonstrating that this weak support is in part because of conflict in the phylogenetic signals of cranial versus postcranial characters. PBS helps identify homoplasy among characters from various body regions, presumably the result of convergent evolution within discrete anatomical modules. It is likely that at least some of this character conflict results from different body regions evolving at different rates, which may have been under different selective pressures. 
1 Revised Phylogenetic Analysis of the Aetosauria

2 (Archosauria: Pseudosuchia); Assessing the Effects of

3 Incongruent Morphological Character Sets

4

5 William Gibson Parker

6

$7 \quad{ }^{1}$ Division of Resource Management, Petrified Forest National Park, Petrified Forest, Arizona, USA

$8 \quad{ }^{2}$ Jackson School of Geosciences, The University of Texas at Austin, Austin, Texas, USA

11 Corresponding Author:

12

13 William Parker ${ }^{1}$

141 Park Road, P. O. Box 2217, Petrified Forest, Arizona, 86028, USA

Email address: William_Parker@nps.gov 
29 ABSTRACT

30 Aetosauria is an early-diverging clade of pseudosuchians (crocodile-line archosaurs) that had a

31 global distribution and high species diversity as a key component of various Late Triassic

32 terrestrial faunas. It is one of only two Late Triassic clades of large herbivorous archosaurs, and

33 thus served a critical ecological role. Nonetheless, aetosaur phylogenetic relationships are still

34 poorly understood, owing to an overreliance on osteoderm characters, which are often poorly

35 constructed and suspected to be highly homoplastic. A new phylogenetic analysis of the

36 Aetosauria, comprising 27 taxa and 83 characters, includes more than 40 new characters that

37 focus on better sampling the cranial and endoskeletal regions, and represents the most

38 comprenhensive phylogeny of the clade to date. Parsimony analysis recovered three most

39 parsimonious trees; the strict consensus of these trees finds an Aetosauria that is divided into two

40 main clades: Desmatosuchia, which includes the Desmatosuchinae and the Stagonolepidinae, and

41 Aetosaurinae, which includes the Typothoracinae. As defined Desmatosuchinae now contains

42 Neoaetosauroides engaeus and several taxa that were previously referred to the genus

43 Stagonolepis, and a new clade, Desmatosuchini, is erected for taxa more closely related to

44 Desmatosuchus. Overall support for some clades is still weak, and Partitioned Branch Support

45 (PBS) is applied for the first time to a strictly morphological dataset demonstrating that this weak

46 support is in part because of conflict in the phylogenetic signals of cranial versus postcranial

47 characters. PBS helps identify homoplasy among characters from various body regions,

48 presumably the result of convergent evolution within discrete anatomical modules. It is likely

49 that at least some of this character conflict results from different body regions evolving at

50 different rates, which may have been under different selective pressures. 


\section{INTRODUCTION}

53
The goal of phylogenetic systematics is to determine phylogenetic relationships of organisms based on shared homologous character states, and to use this information to interpret the evolutionary histories of clades, or monophyletic lineages of organisms, as well as the histories of various evolutionary character transformations (e.g., Wiley and Lieberman, 2011). This presents special challenges for vertebrate groups with extensive carapaces of dermal armor like those of aetosaurian and ankylosaurid archosaurs, which are comprised of hundreds of individual osteoderms (e.g., Desojo et al., 2013). Whereas these osteoderms may be common in the fossil record, they are generally dissociated from the rest of the skeleton prior to burial (Heckert and Lucas, 2000). It has been asserted for aetosaurians that osteoderms provide an exhaustive source of phylogenetically informative character data above and beyond that provided by the underlying skeleton (e.g., Long and Ballew, 1985; Heckert and Lucas, 1999; Parker, 2007), but it has also been argued that, while informative, these data may be plagued with phylogenetically confounding homoplasy (Parker, 2007, 2008a). The specific goal of this paper is to confront these assertions analytically, first by undertaking an expanded phylogeny of aetosaurian archosaurs based on the largest taxonomic sample yet assembled, using a suite of characters that samples both osteoderms and endoskeletal characters; and second, by applying a new method (Partitioned Branch Support) to assess character support and conflict within an entirely morphological dataset.

\section{Historical Background}

Aetosaurians are quadrupedal, pseudosuchian archosaurs characterized by anteroposteriorly shortened skulls with upturned snouts, and heavy armor carapaces, as well an armor 
76 plastron (Figure 1; Walker, 1961; Desojo et al., 2013). They had a global distribution during the

77 Late Triassic and are often used as index fossils for biostratigraphic correlations (Heckert \&

78 Lucas, 1999; Desojo et al., 2013). The paramedian osteoderms possess a diagnostic surface

79 ornamentation that allows for assignment of osteoderms and associated material to specific taxa,

80 although as previously mentioned some of these osteoderm characters may be homoplastic (Long

81 \& Ballew, 1985; Parker, 2007). Accordingly it has been argued that characters from the lateral

82 osteoderms may be more phylogenetically informative than those from the paramedian series

83 (Parker, 2007).

84 When Long \& Ballew (1985) first proposed a taxonomy of North American aetosaurs

85 based exclusively on osteoderm characters, they recognized only four taxa (Desmatosuchus,

86 Typothorax, Calyptosuchus, Paratypothorax). Much new work based upon many new specimens

87 reveals that the particular osteoderm character combinations proposed by Long \& Ballew (1985)

88 in fact can occur in many other unique combinations, resulting in the establishment of many new

89 taxa from North America based almost solely on osteoderms (e.g., Zeigler, Heckert \& Lucas,

90 2003; Martz \& Small, 2006; Spielmann et al., 2006; Lucas, Hunt \& Spielmann, 2007, Parker,

91 Stocker \& Irmis, 2008; Heckert et al., 2015). Moreover, it has been demonstrated that aetosaurs

92 with nearly identical osteoderm character combinations can differ significantly in the other

93 portions of the skeleton, especially in the cranial elements, indicating even more taxonomic

94 potential (Desojo, 2005; Desojo \& Báez, 2005, 2007; Desojo \& Ezcurra, 2011). Finally,

95 aetosaurian osteoderm characters are not intraorganisimally homogeneous (i.e. characters can

96 differ depending on position within the same carapace) and capturing this variation in the

97 construction of phylogenetically informative characters is challenging (Harris, Gower \&

98 Wilkinson, 2003; Parker, 2007; Parker, 2008b; Desojo et al., 2013). 
Although early studies did focus on character change across broadly defined carapace regions such as the cervical and caudal regions (e.g., Long \& Ballew, 1985; Heckert \& Lucas,

101 1999), more recent studies have sought to detail variation within those subregions (Martz, 2002;

102 Parker, 2003; 2008b; Schoch, 2007; Parker \& Martz, 2010; Heckert et al., 2015). Potentially

103 further complicating this situation is our general lack of data regarding character transformations

104 affected by ontogenetic variation as well as differences caused by individual and sexual

105 dimorphism (Taborda, Cerda \& Desojo, 2013; Taborda, Heckert \& Desojo, 2015). Overall

106 though, the rich source of character data present in aetosaurian osteoderms provides the

107 systematist with a broad canvas on which to construct a detailed phylogenetic hypothesis,

108 presuming of course that the changes in osteoderm characters are indeed phylogenetically

109 informative (Parker, 2007) and that the homology of these characters can be determined (e.g.,

110 Harris, Gower \& Wilkinson, 2003; Parker \& Martz, 2010; Heckert et al., 2015).

111 At present we do not have an appropriate sample size across all clades to capture all of

112 intraorganisimal character variation that occurs across the aetosaurian carapace and plastron.

113 Indeed, many taxa are currently only known from a handful of associated osteoderms (e.g.,

114 Tecovasuchus, Apachesuchus, Rioarribasuchus), with the current challenge simply lying in

115 determining the proper position of these osteoderms within the carapace (Lucas, Heckert \&

116 Hunt, 2003; Martz \& Small, 2006; Spielmann et al., 2006; Parker, 2007; Lucas, Hunt \&

117 Spielmann, 2007; Parker \& Martz, 2010; Spielmann and Lucas, 2012). As more discoveries are

118 made, particularly of associated and articulated specimens, our increased understanding of

119 positional variation should allow for more precise placement of isolated osteoderms leading to

120 stronger determinations of homology of individual osteoderms (Parker, 2007; Parker \& Martz,

121 2010; Heckert et al., 2015). 
122 For this study all previously recommended characters used for determination of

123 aetosaurian systematics were reviewed (Parrish, 1994; Heckert, Hunt \& Lucas, 1996; Heckert \&

124 Lucas, 1999; Desojo, 2005; Parker, 2007; Desojo, Ezcurra \& Kischlat, 2012; Roberto-Da-Silva

125 et al., 2014; Heckert et al., 2015). Characters were discarded if found to be generally

126 uninformative or ambiguously scored. The retained characters, as well as new characters, have

127 been rewritten to be more descriptive and thus hopefully easier to interpret and score. Although

128 the retention and construction of many characters and associated character states would

129 presumably lead to better resolution and clade support (Hillis, Huelsenbeck \& Cunningham,

130 1994), the goal of any phylogenetic analysis is accuracy, and this should not come at the expense

131 of artificial resolution by including ambiguously written characters (Slowinski, 1993). Thus, the

132 overarching goal of this project was to recover phylogenetic trees that seem logical given our

133 anatomical understanding of aetosaurians, rather than highly resolved and supported trees that

134 appear problematic and nonsensical in these regards. The matrix of Parker (2007), which has

135 been used as the basis for many recent phylogenetic analyses (Parker, Stocker \& Irmis, 2008;

136 Desojo, Ezcurra \& Kischlat, 2012, Roberto-Da-Silva et al., 2014; Heckert et al., 2015), is

137 dominated by osteoderm characters. This is problematic given the large amount of discovered

138 homoplasy in this dataset (Parker, 2007; Desojo, Ezcurra \& Kischlat, 2012), and in light of the

139 underlying assumption that osteoderm characters provide the main phylogenetic signal for the

140 clade irrespective of the rest of the skeleton (Desojo, 2005; Parker, 2007, 2008b). For these

141 reasons this study sought to increase the number of non-osteoderm characters, as suggested by

142 Desojo (2005) and Desojo, Ezcurra \& Kischlat (2012). This presents challenges because of the

143 relative infrequency of aetosaurian postcranial remains, which are lacking for many taxa or

144 sometimes obscured by articulated carapaces. One of the best sources for aetosaurian postcranial 
145 bones is the Placerias Quarry in northeastern Arizona (Long \& Murry, 1995). However, owing

146 to a lack of association with diagnostic osteoderm material, most of these postcranial elements

147 cannot unequivocally be referred to species (Parker, 2005a; differing from Long \& Murry, 1995;

148 Parker, 2014). Fortunately, there is cranial material preserved for many aetosaurian taxa and

149 almost every known skull, with the exception of some elements from the Placerias Quarry and

150 the Post Quarry (Texas), are unambiguously associated with osteoderms allowing for a precise

151 taxonomic referral. Thus, the present analysis was able to significantly expand the number of

152 cranial characters utilized.

153 The original basis for aetosaurian phylogenetic characters and character transformations

154 is a table of information published by Long \& Ballew (1985:58) where comparisons are provided

155 between various North American taxa, establishing a key early character-based taxonomic

156 scheme for aetosaurians (also see Walker, 1961). Several of these characters are still utilized in

157 recent phylogenetic analyses. The first computed phylogenetic analysis of aetosaurians (Parrish,

158 1994) examined 15 characters (six osteoderm, nine non-osteoderm) and eight taxa. However,

159 nine of those characters are parsimony-uninformative for the ingroup, and there are several

160 incorrect scorings and typographical errors that affect the analysis; thus the published tree is

161 neither well-resolved, nor accurate in its character state distributions (Harris, Gower \&

162 Wilkinson, 2003). Heckert, Hunt \& Lucas (1996) expanded on Parrish's (1994) work, inflating

163 the matrix to nine taxa and 22 (potentially 23) characters (17 armor, five non-armor). That study

164 was also affected by some scoring errors, as well as the lack of use of a non-aetosaurian outgroup

165 to root the resulting trees (Harris, Gower \& Wilkinson, 2003), but did include many new

166 characters that have been used in subsequent aetosaurian phylogenetic studies . Furthermore that 
167 study was the first to unambiguously recover the major clades Desmatosuchinae and

168 Typothoracisinae (sensu Parker, 2007).

169 Heckert \& Lucas (1999) aimed to expand the matrix of Heckert, Hunt \& Lucas (1996),

170 mainly to determine the phylogenetic relationships of a new taxon, Coahomasuchus kahleorum.

171 Their published matrix consisted of 13 in-group taxa and 60 characters. However, 26 of these

172 characters as coded were parsimony uninformative, and as noted by Harris, Gower \& Wilkinson

173 (2003) the published matrix included several typographical errors. When corrected, that matrix

174 produced a tree that was different from the published one. Harris, Gower \& Wilkinson (2003)

175 were critical of several other aspects of this study, including the ad hoc deletion of taxa from the

176 matrix when safe methods to determine appropriate taxon deletion were available (e.g.,

177 Wilkinson, 1995a), and character constructions that inflated seemingly non-independent

178 character suites and biased the resulting tree (composite versus reductive coding; Rowe, 1988;

179 Wilkinson, 1995b). Nonetheless, the study by Heckert \& Lucas (1999) built further upon the

180 character list of Heckert, Hunt \& Lucas (1996) and represents a very important progression in

181 our understanding of aetosaurian systematics.

182 The most recent core phylogenetic analysis of aetosaurians (Parker, 2007) focused on the

183 lateral osteoderms, whereas the previous studies had focused more on characters of the

184 paramedian osteoderms (Heckert, Hunt \& Lucas, 1996; Heckert \& Lucas, 1999). Parker (2007)

185 noted that aetosaurians could roughly be divided into three groups based on the overall anatomy

186 of the lateral osteoderms. This translated into a phylogenetic analysis (16 in-group taxa, 37

187 characters) that recovered three distinct clades: Aetosaurinae, Desmatosuchinae (Heckert \&

188 Lucas, 2000) and Typothoracinae. Whereas support for Desmatosuchinae and Typothoracinae

189 was strong, especially for the subclade Paratypothoracini, Aetosaurinae was unresolved and 
190 weakly supported. This became especially apparent when other taxa were subsequently added to

191 the matrix, causing significantly different tree topologies and character support (Parker, Stocker

192 \& Irmis, 2008; Desojo, Ezcurra \& Kischlat, 2012). Indeed, a recent study (Desojo, Ezcurra \&

193 Kischlat, 2012) failed to recover Aetosaurinae as a clade, with Aetosaurus ferratus as the only

194 member by definition (Heckert \& Lucas, 2000). Desmatosuchinae is always recovered and well-

195 supported, but relationships within the clade are not always fully resolved (e.g., Parker, Stocker

196 \& Irmis, 2008); however, Typothoracinae remains well-supported and resolved. Nonetheless,

197 criticisms of the Parker (2007) dataset include the lack of endoskeletal characters as well as some

198 scoring errors (see Desojo \& Ezcurra, 2011; Desojo, Ezcurra \& Kischlat, 2012; Heckert et al., 199 2015).

Materials and Methods

202

In order to test these questions about taxon sampling, character independence, and tree topology, the matrix has been expanded to include more taxa and characters. The new matrix

204 (Appendix A) utilizes 83 characters for 26 ingroup taxa. The characters are well-divided between 205 anatomical regions, with endoskeletal characters constituting the majority ( 34 cranial, 16 axial/appendicular, 33 osteoderm).

The 26 in-group taxa include the majority of aetosaurian taxa currently considered valid (Desojo et al., 2013; Roberto-Da-Silva et al., 2014; Heckert et al., 2015). They are listed below, and this study is the first to investigate the phylogenetic positions of Adamanasuchus

210 eisenhardtae, Apachesuchus heckerti, Stagonolepis olenkae, Redondasuchus rineharti as well as

211 a new taxon, Scutarx deltatylus gen. et sp. nov. Other taxa are rescored (e.g., Coahomasuchus

212 kahleorum; Typothorax coccinarum) based on new referred material. 
214 Redondasuchus reseri Hunt \& Lucas, 1991; Typothorax antiquum Lucas, Heckert \& Hunt, 2003;

215 and Chilenosuchus forttae Casamiquela 1980. Acaenasuchus and Chilenosuchus were excluded

216 because Chilenosuchus presently scores as a taxonomic equivalent (sensu Wilkinson, 1995a) of

217 Typothorax coccinarum, and newly recognized material, including vertebrae and fused

218 osteoderms, of Acaenasuchus casts doubt on its aetosaurian identify (Parker, unpublished data).

219 Redondasuchus reseri is poorly known and presently scores as a taxonomic equivalent of

220 Redondasuchus rineharti; whereas Typothorax antiquum represents an ontogenetic stage of

221 Typothorax coccinarum rather than a distinct species (Parker, 2006; Parker \& Martz, 2011;

222 Martz et al., 2013). In any case, in this matrix Typothorax antiquum and Typothorax coccinarum

223 are taxonomic equivalents (i.e., they are scored exactly the same, and thus can obscure

224 relationships in the data if both are included; Wilkinson, 1995a), so the less complete,

225 Typothorax antiquum, is excluded.

226 Revueltosaurus callenderi is included in the analysis as an outgroup because it is

227 currently recovered as the sister taxon of Aetosauria (Nesbitt, 2011). Furthermore, it is known

228 from several specimens, which preserve nearly the entire skeleton (Parker, unpublished data).

229 Postosuchus kirkpatricki is utilized as an outgroup because it is relatively complete, well-

230 described and illustrated (Weinbaum, 2011, 2013). Furthermore, it represents a more crownward

231 clade (Paracrocodylomorpha) within Pseudosuchia providing a deeper optimization of character

232 states than can be provided by Revueltosaurus. Both of these taxa have been utilized as

233 outgroups in previous phylogenetic studies of the Aetosauria (e.g., Heckert \& Lucas, 1999;

234 Parker, 2007; Desojo, Ezcurra \& Kischlat, 2012; Heckert et al., 2015). Unfortunately neither

235 Postosuchus nor Revueltosaurus can presently be scored for lateral osteoderm characters and 
236 therefore these characters have been scored as inapplicable for these taxa. Furthermore, most of

237 the paramedian osteoderm characters were scored as inapplicable for Postosuchus because even

238 though Postosuchus possesses dorsal osteoderms, the homology of characters such as

239 ornamentation pattern and presence of certain processes cannot be determined.

240 A previous work (Parker, 2007) incorporated many scorings from past studies (Parrish,

241 1994; Heckert, Hunt \& Lucas, 1996; Heckert \& Lucas, 1999) some of which were later

242 determined to be erroneous (Schoch, 2007; Desojo \& Ezcurra, 2011; Desojo, Ezcurra \&

243 Kischlat, 2012; Heckert et al., 2015). Therefore for this study the matrix was scored from scratch

244 and the scorings completed from carefully studying materials first hand for most taxa, and using

245 photos and the literature for any not studied first-hand (Stagonolepis olenkae, Aetosaurus

246 ferratus, SMNS 19003 [Desojo \& Schoch, 2014], Stenomyti huangae, Redondasuchus rineharti,

247 Gorgetosuchus pekinensis, Polesinesuchus aurelioi). Much effort was directed toward detecting

248 and fixing typographic errors, which can have a major effect on the final tree topologies (Harris,

249 Gower \& Wilkinson, 2003). Scoring completeness is shown in Supplemental Table 1 for each

250 taxon, with inapplicable characters counted as scored. Completeness scores range from $98 \%$ ( 80

251 of 82) for Desmatosuchus smalli, which is known from several skulls and skeletons; to $22 \%$ for

252 Apachesuchus heckerti (18 of 82), which is known only from five paramedian osteoderms. The

253 average completeness score was $60 \%$. The major factor causing incompleteness is a lack of skull

254 material, which affected all taxa that scored lower than 50\%. Because aetosaurians are generally

255 identified by armor characters, there are no taxa that consist solely of cranial material, in contrast

256 with many other groups (e.g., synapsids, dinosaurs).

257

The electronic version of this article in Portable Document Format (PDF) will represent a

258 published work according to the International Commission on Zoological Nomenclature (ICZN), 
259 and hence the new names contained in the electronic version are effectively published under that

260 Code from the electronic edition alone. This published work and the nomenclatural acts it

261 contains have been registered in ZooBank, the online registration system for the ICZN. The

262 ZooBank LSIDs (Life Science Identifiers) can be resolved and the associated information viewed

263 through any standard web browser by appending the LSID to the prefix http://zoobank.org/. The

264 LSID for this publication is: urn:1sid:zoobank.org:pub:841F81C7-A4AE-4146-94FE-

265 DFE0A6725634. The online version of this work is archived and available from the following

266 digital repositories: PeerJ, PubMed Central and CLOCKSS.

267

268 Institutional abbreviations - AMNH, American Museum of Natural History, New York, USA;

269 ANSP, Academy of Natural Sciences of Drexel University, Philadelphia, Pennsylvania, USA;

270 CPE2, Coleção Municipal, São Pedro do Sul, Brazil; DMNH, Perot Museum of Natural

271 History, Dallas, Texas, USA; DMNH, Denver Museum of Nature and Science, Denver,

272 Colorado, USA; FMNH, Field Museum, Chicago, IL, USA; FR, Frick Collection, American

273 Museum of Natural History, New York, USA; MCCDP, Mesalands Community College

274 Dinosaur Museum, Tucumcari, New Mexico, USA; MCSNB, Museo Civico di Scienze Naturali

275 Bergamo, Bergamo, Italy; MCP, Museo de Ciencias e Tecnología, Porto Alegre, Brazil; MCZ,

276 Museum of Comparative Zoology, Harvard University, Cambridge, Massachusetts, USA;

277 MCZD, Marischal College Zoology Department, University of Aberdeen, Aberdeen, Scotland,

278 UK; NCSM, North Carolina State Museum, Raleigh, North Carolina, USA; NHMUK, The

279 Natural History Museum, London, United Kingdom; NMMNH, New Mexico Museum of

280 Natural History and Science, Albuquerque, New Mexico, USA; MNA, Museum of Northern

281 Arizona, Flagstaff, Arizona, USA; PEFO, Petrified Forest National Park, Petrified Forest, 
282 Arizona, USA; PFV, Petrified Forest National Park Vertebrate Locality, Petrified Forest, 283 Arizona, USA; PVL, Paleontología de Vertebrados, Instituto 'Miguel Lillo', San Miguel de 284 Tucumán, Argentina; PVSJ, División de Paleontología de Vertebrados del Museo de Ciencias 285 Naturales y Universidad Nacional de San Juan, San Juan, Argentina, SMNS, Staatliches 286 Museum für Naturkunde, Stuttgart, Germany; TMM, Texas Memorial Museum, Austin, Texas, 287 USA; TTUP, Museum of Texas Tech, Lubbock, Texas, USA; UCMP, University of California, 288 Berkeley, California, USA; ULBRA PVT, Universidade Luterana do Brasil, Coleção de 289 Paleovertebrados, Canoas, Rio Grande do Sul, Brazil; UMMP, University of Michigan, Ann 290 Arbor, Michigan, USA; USNM, National Museum of Natural History, Smithsonian Institution, 291 Washington, D.C., USA; VPL, Vertebrate Paleontology Lab, University of Texas at Austin, 292 Austin, Texas, USA; YPM, Yale University, Peabody Museum of Natural History, New Haven, 293 Connecticut, USA; VRPH, Sierra College, Rocklin, California, USA; ZPAL, Institute of 294 Paleobiology of the Polish Academy of Sciences in Warsaw, Warsaw; Poland.

\section{TERMINAL TAXA}

297

The phylogenetic study by Nesbitt (2011) is currently the basis for most studies of 299 archosauriform relationships (e.g., Nesbitt \& Butler, 2013; Butler et al., 2014). This study utilizes the format used in that study for the listing of terminal taxa and characters to make this work compatible. 
305 Holotype - PEFO 34638, partial skeleton including paramedian and lateral osteoderms, several

306 vertebral centra, and a partial femur (Lucas, Hunt \& Spielmann, 2007).

307 Referred Material - PEFO 35093, osteoderm fragments, nasal fragment; PEFO 36806,

308 osteoderm fragments.

309 Remarks -- Lucas, Hunt \& Spielmann (2007) refer a lateral osteoderm (UCMP 126867) to

310 Adamanasuchus eisenhardtae without explanation other than noting a 2007 personal

311 communication from Andrew Heckert. They neither figure nor describe the specimen, but list its

312 provenance as the Placerias Quarry near St. Johns, Arizona and attribute it as another

313 Adamanian record of Adamanasuchus eisenhardtae. Examination of UCMP 126867 confirms

314 the identification of the element as an aetosaurian lateral osteoderm; however, the specimen was

315 collected from PFV 075 (Karen's Point) in Petrified Forest National Park and not from the

316 Placerias Quarry. PFV 075 is in the Martha's Butte beds of the Sonsela Member, which are

317 Revueltian in age (Parker \& Martz, 2011), thus this would represent a range extension of this

318 taxon up into the Sonsela Member and into the Revueltian biozone. This specimen differs from

319 the holotype of Adamanasuchus eisenhardtae in possessing an extremely reduced dorsal flange

320 and a dorsal eminence that forms a broadly triangular "spine" that projects dorsally. The outer

321 surface of the lateral flange and the dorsal eminence bear an elongate ridge, which is located

322 very close to the plate margin. Curiously the osteoderm lacks an anterior bar so it cannot be

323 determined if this margin is the anterior or posterior edge. In Adamanasuchus eisenhardtae, the

324 lateral osteoderms are more symmetrical with nearly equal lateral and dorsal flanges, and the

325 eminence does not form a projected spine (PEFO 34638). Because of these anatomical

326 differences and the discrepancy in the stratigraphic and locality data, the referral of this specimen

327 to Adamanasuchus eisenhardtae is not supported. 
PEFO 35093 includes osteoderm fragments that possess the unique surface

329

330

331

332

333

334

335

336

337

338

339

340

341

342

343

344

345

346

347

348

349

350

ornamentation of a faint background, radial pattern, 'overprinted' by deep randomly developed

pits. This 'overprinting' is characteristic of Adamanasuchus eisenhardtae and differs from other

aetosaurians with a radial ornamentation pattern (Lucas, Hunt \& Spielmann, 2007). An

associated fragment of a nasal most likely belongs to the same specimen as it has an identical

preservation and no other aetosaur specimens were recovered from the immediate area.

Unfortunately the nasal fragment is too incomplete to provide more information. PEFO 36806 is another referred specimen and consists solely of osteoderm fragments. Both PEFO 35093 and PEFO 36806 were recovered from the upper part of the Blue Mesa Member at about the same stratigraphic horizon as the holotype specimen of Adamanasuchus eisenhardtae.

Age - Late Triassic, early to middle Norian, Adamanian (Ramezani et al., 2011; Parker \& Martz, 2011).

Occurrence - upper Blue Mesa Member, Chinle Formation, Petrified Forest National Park, Arizona, U.S.A. (Lucas, Hunt \& Spielmann, 2007; Parker \& Martz, 2011).

Remarks - Lucas, Hunt \& Spielmann (2007a) named Adamanasuchus eisenhardtae for a partial skeleton collected from the upper part of the Blue Mesa Member (Chinle Formation) in Petrified Forest National Park in 1996 (Hunt, 1998; Parker, 2006). Parker (2006) incorrectly assigned this specimen to Typothorax antiquum based on interpretation of comments made by Hunt (1998) regarding this specimen. In 2010 park staff revisited the type locality and finished the excavation; several paramedian and lateral osteoderms had been covered and left by the original workers and these materials were not included in the original description. The diagnosis provided by Lucas, Hunt \& Spielmann (2007) does not adequately differentiate Adamanasuchus eisenhardtae from other known aetosaurians, in particular from Calyptosuchus wellesi; however, 
351 key characters found in Adamanasuchus eisenhardtae to the exclusion of Calyptosuchus wellesi

352 are the strongly sigmoidal lateral edge, that results is a ventrolateral corner of the osteoderm that

353 appears to have been sheared-off, and a triangular patch in the posteromedial corner of the

354 paramedian plate surface that is smooth and devoid of ornamentation. The first character state

355 also occurs in paratypothoracins and the second is found in a new aetosaur species described

356 below (e.g., PEFO 34616), except that in the latter taxon the triangular area is strongly raised.

357 Key References - Lucas, Hunt \& Spielmann (2007).

358

Aetobarbakinoides brasiliensis Desojo, Ezcurra \& Kischlat 2012.

360

361 Holotype - CPE2 168, partial postcranial skeleton (Desojo, Ezcurra \& Kischlat, 2012). A cast of

362 this specimen is in the Petrified Forest National Park (PEFO) collections.

363 Referred Material - none.

364 Age - Late Triassic, late Carnian - earliest Norian, Hyperodapedon Assemblage Zone (Langer et

365 al., 2007; Martinez et al., 2011).

366 Occurrence - Sequence 2, Santa Maria Supersequence, Rio Grande Do Sul, Brazil (Desojo,

367 Ezcurra \& Kischlat, 2012).

368 Remarks - The holotype (CPE2 168) of Aetobarbakinoides brasiliensis is a fragmentary

369 postcranial skeleton of a small aetosaurian that was originally referred to Stagonolepis robertsoni

370 (=Aetosauroides in their hypothesis) by Lucas \& Heckert (2001). The lack of open neurocentral

371 sutures in the cervical and trunk vertebrae suggests that CPE2 168 represents a skeletally mature

372 individual (Irmis, 2007). Despite the fragmentary preservation of the holotype, Desojo \& Ezcurra

373 (2011) were able to distinguish this material from that of other South American aetosaurs, based 
374 on the presence of discrete vertebral laminae in the trunk series, a character lacking in taxa such

375 as Aetosauroides scagliai and Neoaetosauroides engaeus. Furthermore, Aetobarbakinoides is the

376 only South American aetosaurian specimen with trunk vertebrae that bear accessory articular

377 structures (i.e. hyposphene), a feature recognized previously in aetosaurians only in

378 desmatosuchines (Parker, 2008b). Determining the phylogenetic position of this taxon is difficult

379 because it is represented primarily by endoskeletal (non-osteoderm) material. A few osteoderms

380 are present, but the surface ornamentation is poorly preserved. Lateral osteoderms, which have

381 been key to phylogenetic placement (Parker, 2007), are not preserved. Furthermore, the

382 preserved paramedian osteoderms lack their lateral edges, which, if preserved, would have

383 provided information about the medial edges of the lateral osteoderms allowing for the scoring of

384 some characters. Desojo, Ezcurra \& Kischlat (2012) recovered Aetobarbakinoides brasiliensis as

385 the sister taxon of the clade Desmatosuchinae + Typothoracinae; however, Heckert et al. (2015)

386 considered it to be a 'wildcard' (unstable) taxon in their analysis and pruned it a posteriori from

387 their published tree. It performed as a wildcard taxon in the present analysis as well, which is

388 discussed in more detail below.

389 Key References - Desojo, Ezcurra \& Kischlat (2012).

390 Aetosauroides scagliai Casamiquela 1960

391

392 Holotype - PVL 2073, postcranial skeleton including the majority of the carapace, vertebral

393 column, and sacrum in articulation (Casamiquela, 1961).

394 Referred Material - see Desojo and Ezcurra (2011).

395 Age - Late Triassic, Carnian, Hyperodapedon Assemblage Zone (Rogers et al.,1993;

396 Furin et al., 2006; Martinez et al., 2011). 
397 Occurrence - Cancha de Bochas Member, Ischigualasto Formation, Argentina; Sequence 2,

398 Santa Maria Supersequence, Rio Grande do Sul State, Brazil (Casamiquela, 1961; Desojo \&

399 Ezcurra, 2011).

400 Remarks - Aetosauroides scagliai was originally described by Casamiquela $(1960,1961)$ based

401 on well-preserved cranial and postcranial material from the lower part of the Ischigualasto

402 Formation of Argentina. Further material was assigned by Casamiquela (1967) who redescribed

403 the specimens in light of the monograph on Stagonolepis robertsoni by Walker (1961). Strong

404 similarities have been noted between Aetosauroides and Stagonolepis as well as Aetosaurus and

405 based on element size Aetosauroides was considered to be somewhat morphologically

406 transitional between the two European taxa (Casamiquela, 1967). In an unpublished masters

407 thesis, Zacarias (1982) erected a second species of Aetosauroides (“Aetosauroides subsulcatus")

408 for material from the Upper Triassic of Brazil. All of this material has been briefly redescribed,

409 the majority of it assigned to Stagonolepis robertsoni (Lucas \& Heckert, 2001; Heckert \& Lucas,

410 2002). Those authors argued that only superficial differences could be found between all of

411 these specimens and that assignment of the South American material strengthened previously

412 proposed biostratigraphic correlations between Brazil, Argentina, and the U.K., as well as to the

413 southwestern United States. In contrast, Desojo \& Ezcurra (2011) assigned the Brazilian material

414 to Aetosauroides scagliai based on the presence of well-developed fossae on the lateral sides of

415 the dorsal vertebrae and the exclusion of the maxilla from the external naris in the skull of

416 Aetosauroides scagliai, a character first noted by Casimiquela (1967). A phylogenetic analysis

417 recovered Aetosauroides scagliai as the sister taxon to all other aetosaurs (Stagonolepididae)

418 (Desojo, Ezcurra \& Kischlat, 2012). Redescriptions of the Argentinian material were presented 
419 in two unpublished dissertations (Desojo, 2005; Parker, 2014), and a full redescription by Desojo

420 and Ezcurra is in progress (J. Desojo, pers. comm., 2014).

421 The cranial material of Aetosauroides scagliai is significant because it exemplifies the

422 plesiomorphic aetosaurian skull condition, optimizing characters such as the exclusion of the 423 maxilla from the external naris, frontals that are wider than the parietals, nasals that taper 424 anteriorly, a large triangular depression present anterior to the frontals, the lack of a 'slipper425 shaped' mandible, the lack of a basal swelling in the teeth, and the mediolaterally compressed 426 teeth with recurved tips (Parker, 2014). The skull is significantly different from that of

427 Stagonolepis robertsoni, Stagonolepis olenkae, Neoaetosauroides engaeus, and Calyptosuchus 428 wellesi and that characters of the osteoderms used to unite these taxa (e.g., Heckert \& Lucas 429 2002) are homoplasious (Desojo \& Ezcurra, 2011; Parker 2008b).

430 Cerda \& Desojo (2011) provide details of the osteoderm histology of Aetosauroides 431 scagliai, although using referred specimens rather than the holotype. This adds to the increasing 432 understanding of the bone histology of aetosaurians (e.g., Parker, Stocker \& Irmis, 2008;

433 Scheyer, Desojo \& Cerda, 2013). It is possible that once histological features and their 434 relationships with ontogenetic maturity at time of death and potential environmental effects are 435 better known, that histological characters can be incorporated in phylogenetic analyses of the 436 Aetosauria.

438 Key References - Casimiquela, 1960, 1961, 1967; Heckert \& Lucas, 2002; Desojo \& Ezcurra, 439 2011; Cerda \& Desojo, 2011; Parker, 2014. 


\section{Aetosaurus ferratus Fraas 1877}

442

443 Lectotype-SMNS 5770, specimen XVI (16) (Schoch, 2007).

444 Referred Material - SMNS 5770, at least 24 specimens recovered in the same block as the

445 lectotype; SMNS 18554, articulated skeleton lacking the skull and pectoral girdle; SMNS 14882,

446 articulated caudal segment; SMNS 12670, dorsal and ventral osteoderms; MCZ 22/92G, partial

447 skull, limb bones and vertebrae, osteoderms; MCSNB 4864, dorsal osteoderms.

448 Age - Late Triassic, middle Norian to early Rhaetian, Revueltian (Deutsche Stratigraphische

449 Kommission, 2005; Lucas, 2010).

450 Occurrence - Lower and Middle Stubensandstein, Löwenstein Formation, Germany; Calcare de

451 Zorzino Formation, Italy; Ørsted Dal Member, Fleming Fjord Formation, eastern Greenland

452 (Wild, 1989; Jenkins et al., 1994; Schoch, 2007).

453 Remarks - The genus Aetosaurus originally included two species, Aetosaurus ferratus and

454 Aetosaurus crassicauda. Aetosaurus crassicauda is presently understood to represent a larger

455 specimen of Aetosaurus ferratus (Schoch, 2007). Specimens of Stegomus arcuatus from eastern

456 North American have been assigned to Aetosaurus (Lucas, Heckert \& Huber, 1998); however,

457 the majority of this material consists of natural molds that do not preserve the surface

458 ornamentation. These specimens are assignable to Aetosaurus only on the basis of "aetosaurine"

459 (sensu Parker, 2007) synapomorphies such as a sigmoidal lateral margin of the paramedian

460 osteoderms with a pronounced anterolateral projection, as well as their small size. Small

461 osteoderms (e.g., NMMNH P-17165) from the Bull Canyon Formation of New Mexico referred

462 to Stegomus (Aetosaurus) arcuatus by Heckert \& Lucas (1998) possess an anterior bar, radial

463 pattern, offset dorsal eminence, and an anterolateral projection, which are "aetosaurine"

464 characters and not diagnostic of a less inclusive taxon. Several authors consider the lack of dorsal 
465 ornamentation, including a dorsal eminence (boss) in the osteoderms of Stegomus (Aetosaurus)

466 arcuatus to be diagnostic of the taxon (e.g., Heckert \& Lucas, 2000; Heckert et al., 2001;

467 Spielmann \& Lucas, 2012); however, the lack of ornamentation is because the type and key

468 referred specimens consist solely of natural molds of the ventral surfaces of the osteoderms

469 which are typically smooth and unornamented in aetosaurs.

470 Purported specimens of Aetosaurus ferratus from the Chinle Formation of Colorado

471 (Small, 1998) are now considered to represent a distinct taxon, Stenomyti huangae (Small \&

472 Martz, 2013). Aetosaurus has also been recognized from Greenland and Italy. The Greenland

473 material consists of a partial skull, postcranial skeleton and osteoderms (MCZ 22/92G; Jenkins et

474 al., 1994). This skull possesses the following characteristics of Aetosaurus ferratus; an

475 anteroposteriorly short jugal, a round supratemporal fenestra; and an antorbital fossa that covers

476 the majority of the lacrimal (Schoch, 2007). The Italian material (MCSNB 4864) consists of a

477 short series of articulated dorsal paramedian and lateral osteoderms that possess an identical

478 surface ornamentation to Aetosaurus ferratus (Wild, 1989). This specimen is significant as it was

479 recovered from marine sediments of Norian age and represents a potential tie point to the marine

480 biostratigraphic record for the Late Triassic (Lucas, 1998a, Irmis et al., 2010).

481 In summary, Aetosaurus ferratus is presently known from Greenland, Germany, and

482 Italy, and other purported North American occurrences cannot be substantiated (Schoch, 2007;

483 Small \& Martz, 2013). For this study Aetosaurus ferratus is scored only from the German

484 lectotype and referred material.

485 Key References - Wild, 1989; Jenkins et al., 1994; Schoch, 2007.

486 
487 Apachesuchus heckerti Spielmann and Lucas 2012

488

489

490

491

492

493

494

495

496

497

498

499

500

501

502

503

504

505

506

507

508

509

510

Holotype - NNMNH P-31100, left dorsal paramedian osteoderm.

Referred material - NMMNH P-63427, left cervical paramedian osteoderm; NMMNH P-63426, right caudal paramedian osteoderm. Both of these specimens were originally included in NMMNH P-31100 (Heckert et al., 2001; Spielmann \& Lucas, 2012:fig. 70e), but have been renumbered. Spielmann \& Lucas (2012) also report that much more complete material of this taxon, including postcrania, is currently under study by Axel Hungerbühler at the Mesalands Dinosaur Museum in Tucumcari, New Mexico. This new material is also from the Redonda Formation of New Mexico; however, the new material referable to Apachesuchus heckerti only consists of a few more paramedian osteoderms, whereas the rest of the material is actually referable to Redondasuchus rineharti (J. Martz, pers. comm., 2013).

Age - Late Triassic, late Norian-Rhaetian, Apachean (Spielmann \& Lucas, 2012).

Occurrence - Quay Member, Redonda Formation, Dockum Group, New Mexico, U.S.A (Spielmann \& Lucas, 2012).

Remarks - The holotype and paratype (referred) osteoderms were recovered in a microvertebrate assemblage found within a very large phytosaur skull and were originally assigned to Neoaetosauroides sp. because the lack of surface ornamentation of the paramedian osteoderms was thought to be diagnostic of Neoaetosauroides (Heckert et al., 2001). However, the lack of surface ornamentation of some of the osteoderms of the holotype of Neoaetosauroides is the result of overpreparation of the specimen and close examination shows that the material does have a surface orientation of radial grooves and ridges; therefore the NMMNH material cannot be assigned to that taxon. The lack of surface ornamentation in the type material of Apachesuchus heckerti appears to be a genuine feature and is considered an autapomorphy of the 
511 taxon (Spielmann \& Lucas, 2012; J. Martz, pers. comm., 2013). Apachesuchus heckerti is

512 considered to possess a low width/length ratios $(>0.3)$ of the paramedian osteoderms; which was

513 obtained by comparing the length of the lateral edge to the total plate length (Heckert et al.,

514 2001; Spielmann \& Lucas, 2012). However, the lateral edge of NMMNH P-31100 is greatly

515 expanded anteroposteriorly than the rest of the osteoderm strongly skewing this ratio. The length

516 at the center of the osteoderm is $32 \mathrm{~mm}$, compared to an overall width of $104 \mathrm{~mm}$. This provides

517 a width/length ratio of 3.25, compared to the ratio of 2.5 provided by Spielmann \& Lucas (2012).

518 It is important to standardize areas of measurements when determining ratios of aetosaur

519 osteoderms because simply using maximum length can skew results in osteoderms with

520 abnormal shapes. This is also true for osteoderms with elongate anterolateral processes of the

521 anterior bars (e.g., Calyptosuchus wellesi). In these cases osteoderm lengths should be taken

522 from the main osteoderm body and not from the anterior bar. Furthermore, an unnumbered

523 referred anterior dorsal paramedian osteoderm in the Mesalands Community College Dinosaur

524 Museum (MCCDM) collection (field number 20080618RET002RRB) has a width of $110 \mathrm{~mm}$

525 and a median length of $28 \mathrm{~mm}$ for a W/L ratio of 3.92. This compares well with typothoracin

526 aetosaurs such as Typothorax coccinarum (Long \& Murry, 1995; Heckert et al., 2010).

527 Key References - Heckert et al. (2001); Spielmann \& Lucas (2012).

528

529 Calyptosuchus wellesi Long \& Ballew 1985

530

531

Holotype - UMMP 13950, articulated dorsal carapace from the posterior dorsal and caudal

532 regions, associated with a portion of the vertebral column and the sacrum (Case, 1932; Long \&

533 Ballew, 1985). 
534 Referred Material - UMMP 7470, two dorsal paramedian osteoderms, three dorsal vertebrae,

535 mostly complete, articulated sacrum; UCMP 27225, paramedian, lateral, and ventral osteoderms,

536 partial right dentary. Numerous specimens from the Placerias Quarry from the UCMP and the

537 MNA collections, as well as specimens from Petrified Forest National Park also can be referred

538 to Calyptosuchus wellesi (Long \& Murry, 1995; Parker, 2014).

539 Age - Late Triassic, early-middle Norian, early Adamanian (Ramezani et al., 2011; Ramezani,

540 Fastovsky \& Bowring 2014; Parker \& Martz, 2011).

541 Occurrence - upper Blue Mesa Member, Chinle Formation, Arizona, U.S.A.; Tecovas

542 Formation, Dockum Group, Texas, U.S.A (Long \& Murry, 1995; Parker \& Martz, 2011).

543 Remarks - Case (1932) described a posterior portion of a carapace and associated pelvis and

544 vertebral column of what he believed to be a phytosaur from the Upper Triassic of Texas.

545 Although he discussed possible taxonomic affinities he was thoroughly perplexed by the material

546 and thus did not assign the specimen to an existing taxon or coin a new taxonomic name. This is

547 mainly because of the common association of aetosaurian osteoderms with phytosaur remains

548 (e.g., Nicrosaurus kapffi, Case, 1929) and because the osteoderms of UMMP 13950 possessed a

549 radial surface ornamentation more similar to osteoderm material then assigned to the phytosaur

550 Nicrosaurus (=Phytosaurus) kapffi (now the holotype of the aetosaurian Paratypothorax

551 andressorum Long \& Ballew, 1985). This is unlike the surface ornamentation found in the other

552 aetosaurian Case was familiar with, Desmatosuchus spurensis (Case, 1922). Indeed, Case (1932)

553 tentatively suggested that UMMP 13950 may belong to the genus "Phytosaurus". Gregory

554 (1953a) recognized that the specimen was probably more closely related to Typothorax than to

555 phytosaurs and hence most likely a pseudosuchian (aetosaur), but still considered the purported 
556 close similarity of the rectangular osteoderms with those assigned to some phytosaurs to be

557 problematic for taxonomic resolution of the material.

$558 \quad$ This problem was finally resolved by Long \& Ballew (1985) who correctly determined

559 that all of the Triassic material with broad, rectangular osteoderms was referable to aetosaurians.

560 Those authors also listed UMMP 13950 as the holotype of a new genus, Calyptosuchus wellesi.

561 They did not redescribe Case's specimen, but instead discussed the new taxon in terms of

562 referred material from the Triassic of Arizona. A recent description of the taxon is by Long \&

563 Murry (1995) who mainly described referred material from the Placerias Quarry of Arizona. The

564 referrals of material to Calyptosuchus wellesi by Long \& Murry (1995) have been questioned

565 mainly because of the recognition that the cervical lateral osteoderms assigned to Calyptosuchus

566 wellesi by Long \& Ballew (1985) and Long \& Murry (1995) actually belong to a

567 paratypothoracin aetosaur demonstrating the presence of a third aetosaur taxon in the Placerias

568 Quarry (Parker, 2005a, 2007).

569 Parker (2014) carefully sorted and grouped the Placerias Quarry material based on field

570 numbers and used the resulting associations as well as apomorphic comparisons to test these

571 assignments. Referred elements of Calyptosuchus wellesi were redescribed and these referred

572 specimens, as well as the holotype, are used to and score that taxon in this phylogenetic analysis.

573 This anatomical work, in association with detailed biostratigraphic work of the Chinle Formation

574 (Parker \& Martz, 2011), has also determined that Calyptosuchus wellesi is presently restricted to

575 the upper part of the Blue Mesa Member and that specimens of Calyptosuchus noted from the

576 Sonsela Member (e.g., Parker \& Martz, 2011) belong to a new taxon described below.

577 Key References - Case, 1932; Long \& Ballew, 1985; Long \& Murry, 1995; Parker, 2014. 


\section{Coahomasuchus kahleorum Heckert \& Lucas 1999}

580

581

582 1999).

583 Referred Material - TMM 31100-437, partial skull, paramedian, lateral, and ventral osteoderms,

Holotype - NMMNH P-18496, much of an articulated, but crushed skeleton (Heckert \& Lucas,

584

585

vertebrae, limb, and girdle material (Murry \& Long, 1996; this study); NCSM 23168, much of a carapace (Heckert et al., 2015).

586

Age - Late Triassic, ?Carnian, Otischalkian (Lucas, 2010).

587 Occurrence - Colorado City Formation, Dockum Group, west Texas, U.S.A.; Pekin Formation,

588 Newark Supergroup, North Carolina, U.S.A (Heckert \& Lucas, 1999; Heckert et al., 2015).

589 Remarks - The holotype of Coahomasuchus kahleorum is distinctive, but poorly preserved,

590 consisting of a flattened carapace and plastron concealing the majority of the vertebrae, the

591 posteroventral corner of the skull, the posterior portion of the mandible, and a poorly preserved

592 braincase, as well as articulated limb and girdle material (Heckert \& Lucas, 1999; Desojo \&

593 Heckert, 2004). Fraser et al. (2006) documented the first occurrence of Coahomasuchus in the

594 Pekin Formation of North Carolina providing a biostratigraphic correlation with the lower part of

595 the Dockum Group of west Texas. Past phylogenetic analyses have recovered Coahomasuchus

596 kahleorum as the sister taxon of Typothorax coccinarum and Redondasuchus reseri (Harris,

597 Gower \& Wilkinson, 2003 correction of the Heckert \& Lucas, 1999 dataset); as the sister taxon

598 of an unresolved clade containing Aetosauroides, Calyptosuchus, Aetosauroides, and Aetosaurus

599 (Parker, 2007); and in an unresolved position closer to the base of Stagonolepididae (Desojo,

600 Ezcurra \& Kischlat, 2012). Moreover, the latter authors pruned Coahomasuchus from their final

601 tree to achieve better resolution, thus the phylogenetic relationships of this taxon are far from

602 resolved. However, a more recent analysis by Heckert et al. (2015), utilizing a modified version 
603 of the dataset in Parker (2007) and Desojo, Ezcurra \& Kischlat (2012), recovered

604 Coahomasuchus as a non-stagonolepidid aetosaur at the base of Aetosauria. In this analysis

605 Coahomasuchus kahleorum is coded from the holotype as well as a newly referred specimen

606 from the Dockum Group of Texas (TMM 31100-437) previously referred to as the 'carnivorous

607 form' (Murry \& Long, 1996), which was recovered from the same geographical area and stratum

608 as the type specimen (Lucas, Hunt \& Kahle, 1993).

609 It was suggested that the holotype of Coahomasuchus kahleorum may represent a

610 skeletally immature individual (Parker, 2003). However, histological sampling of the referred

611 specimen TMM 31100-437, which is in the same size class, indicates that TMM $31100-437$ is

612 close to skeletal maturity (S. Werning, pers. comm., 2014). Thus, Coahomasuchus kahleorum is

613 most likely not a juvenile individual of Lucasuchus hunti or Longosuchus meadei, both which

614 are found in the same stratigraphic horizon and localities (e.g., Parker \& Martz, 2010).

615 Key References - Heckert \& Lucas (1999); Desojo \& Heckert (2004).

616

617 Desmatosuchus spurensis Case 1920

618

619 Holotype - UMMP 7476, skull, nearly complete carapace, articulated cervical and dorsal

620 vertebral column, ilium (Case, 1922).

621 Referred Material - see Parker, 2008b.

622 Age - Late Triassic, early to middle Norian, Adamanian (Ramezani et al., 2011; Ramezani, 623 Fastovsky \& Bowring 2014; Parker \& Martz, 2011). 
624 Occurrence - Tecovas Formation, Dockum Group, Texas, U.S.A., Los Esteros Member, Santa

625 Rosa Formation, Dockum Group, New Mexico, U.S.A., upper Blue Mesa Member, Chinle

626 Formation, Arizona, U.S.A (Long \& Murry, 1995; Parker, 2008b).

627 Remarks - First described from much of a carapace, and associated vertebral column as well as a

628 skull, Desmatosuchus spurensis is a well-known aetosaurian from the Upper Triassic of the

629 southwestern United States. Despite this, confusion exists regarding characters of the dorsal

630 armor for referral of specimens. For example all of the specimens listed by Long \& Ballew

631 (1985) from Petrified Forest National Park actually pertain to paratypothoracines, and the

632 osteoderm of Desmatosuchus figured by Lucas \& Connealy (2008:26) for the Dawn of the

633 Dinosaurs exhibit at the New Mexico Museum of Natural History and Science is actually and

634 osteoderm of Calyptosuchus wellesi.

635

Gregory (1953a) synonymized Desmatosuchus spurensis with Episcoposaurus

636 haplocerus, a form described by Cope (1892), and the taxon was known as Desmatosuchus

637 haplocerus for several decades, until it was determined that Episcoposaurus haplocerus was

638 actually a nomen dubium (Parker, 2008b; 2013) although this has not been accepted by all

639 workers (e.g., Heckert, Lucas \& Spielmann, 2012). New material from the Chinle Formation of

640 Arizona demonstrated that previous carapace reconstructions for Desmatosuchus spurensis were

641 erroneous and the body was broader than previous believed (Parker, 2008b).

642 Limb and pectoral girdle for Desmatosuchus spurensis is not known from the two best

643 preserved specimens (UMMP 7476, MNA V9300), but Long \& Murry (1995) assigned isolated

644 material from the Placerias Quarry to the taxon, which has been utilized for studies including

645 bone histology (de Ricqlès, Padian \& Horner, 2003). Unfortunately Long \& Murry (1995) did

646 not discuss the evidence for these referrals, which have been questioned (Parker, 2005a, 2008b); 
647 however, utilizing field numbers from the Placerias Quarry it may possible to refer some of this

648 material to Desmatosuchus spurensis. For this analysis Desmatosuchus spurensis is coded from

649 UMMP 7476 and MNA V9300.

650 Key References - Case, 1920, 1922; Long \& Ballew, 1985; Long \& Murry, 1995; Parker, 2008b.

\section{Desmatosuchus smalli Parker 2005}

652

653

Holotype - TTU P-9024, almost complete skull and right mandible, partial pelvis, femora, nearly

654 complete cervical armor and numerous osteoderms from the rest of the carapace (Parker, 2005b).

655 Referred Material - see Parker (2005b) and Martz et al. (2013).

656 Age - Late Triassic, mid-Norian, latest Adamanian and possibly earliest Revueltian (Ramezani et 657 al., 2011; Martz et al., 2013).

658 Occurrence - Middle section of the Cooper Canyon Formation, Dockum Group, Texas, U.S.A. ;

659 ?Martha's Butte beds, Sonsela Member, Chinle Formation, Arizona, U.S.A (Parker, 2005b;

660 Martz et al., 2013).

661 Remarks - Small $(1985,2002)$ described new material of Desmatosuchus from the Cooper

662 Canyon Formation of Texas. Although he noted differences in the cranial material of the new 663 material from the holotype of Desmatosuchus spurensis (UMMP 7476), he did not feel they were 664 of taxonomic significance. In a revision of the genus Desmatosuchus, significant differences in 665 the lateral armor were noted between the Cooper Canyon specimens and the type of 666 Desmatosuchus spurensis (Parker, 2003). Combined with the cranial differences noted by Small

667 (2002) the Cooper Canyon Formation material was assigned to a new species (Parker, 2005b).

668 Further comments regarding this taxon including a novel reconstruction of the lateral cervical 669 armor were provided by Martz et al., (2013). 
Desmatosuchus smalli is that some of it may actually pertain to an undescribed specimen of

672 Paratypothorax from the quarry (Martz, 2008). A detailed apomorphy-based study of the

673 aetosaurian material from the Post Quarry is needed along with a reinvestigation of field

674 collection data to clarify some of the taxonomic assignments of the material (Martz, 2008).

675 Other than the Texas material, Desmatosuchus smalli is known from only one single

676 referred lateral osteoderm from the Chinle Formation of Arizona (MNA V697), which had been

677 assigned to Desmatosuchus by Long \& Ballew (1985) as a cervical lateral osteoderm. MNA

678 V697 actually represents a dorsal lateral osteoderm and is assigned to Desmatosuchus smalli

679 based on the ventrally recurved spine tip, which is an autapomorphy of Desmatosuchus smalli

680 and does not occur in Desmatosuchus spurensis (Parker, 2005b). Although MNA V697 is listed

681 as originating from a locality in the upper part of the Sonsela Member near Petrified Forest

682 National Park (Long \& Ballew, 1985), the locality data for this specimen are ambiguous.

683 However, if correct this would represent the only Revueltian occurrence of Desmatosuchus

684 (Parker \& Martz, 2011).

685 The holotype of Desmatosuchus (=Episcoposaurus) haplocerus (ANSP 14688; Cope,

686 1892) consists chiefly of lateral and paramedian osteoderms of the cervical and anterior dorsal

687 regions (Gregory, 1953a, Parker, 2013). Unfortunately the tips of the spines on all of the dorsal

688 lateral osteoderms are broken away so the material cannot be differentiated between

689 Desmatosuchus spurensis and Desmatosuchus smalli. Interestingly, the shape of the cervical

690 lateral osteoderms as well as the ornamentation of the dorsal paramedian osteoderms are more

691 reminiscent of Desmatosuchus smalli rather than Desmatosuchus spurensis, but the data are not 
692 conclusive and therefore Desmatosuchus haplocerus is considered a nomen dubium (Parker, $6932008 b, 2013)$.

694 Key References - Small, 1985, 2002; Parker, 2005b; Martz et al., 2013.

695

696

697

698

699

700

701

702

703

704

705

706

707

708

709

710

711

712

713

714

\section{Longosuchus meadei (Sawin 1947)}

Lectotype - TMM 31185-84b, skull and much of a postcranial skeleton (Sawin, 1947). See Parker \& Martz (2010) for detailed discussion of the status of the type materials.

Referred Material - TMM 31185-84a, partial skull and postcranial skeleton. See Long and Murry (1995) for a complete list.

Age - Late Triassic,?Carnian, Otischalkian (Lucas, 2010).

Occurrence - Colorado City Formation, Dockum Group, Texas, U.S.A (Hunt \& Lucas, 1990). Remarks - The Works Progress Administration program in the 1930s made vast collections of vertebrate fossils from a series of quarries in strata of the Dockum Group in Howard County, Texas. This included several skeletons of an aetosaurian that Sawin (1947) described as a new species of Typothorax, Typothorax meadei. Several subsequent authors recognized the distinctiveness of this material (Long \& Ballew, 1985; Small, 1989; Murry \& Long, 1989) and the species was placed in a new genus, Longosuchus, by Hunt \& Lucas (1990). Sawin's original description is thorough, but affected by a lack of good comparative material as well as the poor historical understanding of the taxonomic make-up of the Aetosauria available at the time of his initial work. Thus he incorrectly reconstructed the incomplete lower jaw and pelvis, which confused aetosaur in-group relationships until these details were later corrected by Walker (1961). 
716 partial skeletons (unpublished TMM documents), referable to Longosuchus meadei are in the

717 Vertebrate Paleontology Lab (VPL) collections at the University of Texas (Austin) awaiting

718 preparation.

719 An isolated fragment of a paramedian osteoderm from the Salitral Shale (Chinle

720 Formation) of New Mexico, assigned to Longosuchus meadei by Hunt \& Lucas (1990),

721 possesses a beveled posterior edge and a radial ornament pattern and is more likely referable to

722 Paratypothoracini, in particular Tecovasuchus (Irmis, 2008). Lateral osteoderms from the Argana

723 Group of Morocco assigned to Longosuchus meadei by Lucas (1998b) appear to also represent a

724 paratypothoracin as they are strongly dorsoventrally compressed and slightly recurved (Parker \&

725 Martz, 2010). Unfortunately this cannot be tested as these specimens have been reported as lost

726 (S. Nesbitt, pers. comm., 2013). Character state scorings for this study for Longosuchus were

727 made solely utilizing the TMM material.

728 Key References - Sawin, 1947; Hunt \& Lucas, 1990; Long \& Murry, 1995; Parker \& Martz, 7292010.

730

731 Lucasuchus hunti Long \& Murry 1995

732

733 Holotype - TMM 31100-257, posterior dorsal paramedian osteoderm (Long \& Murry, 1995).

734 Referred Material - see Parker \& Martz (2010) and Long \& Murry (1995).

735 Age - Late Triassic,?Carnian, Otischalkian (Lucas, 2010).

736 Occurrence - Colorado City Formation, Dockum Group, Texas, U.S.A.; Pekin Formation,

737 Newark Supergroup, North Carolina, U.S.A (Long \& Murry, 1995; Parker \& Martz, 2010). 
738 Remarks - Long \& Murry (1995) recognized the presence of two distinct large aetosaurian

739 morphotypes in material from the Otis Chalk quarries in Howard County, Texas, the first being

740 Longosuchus meadei and a second for which they coined a new taxon, Lucasuchus hunti. Sawin

741 (1947) had also recognized the presence of this second aetosaurian, which he erroneously

742 assigned to Typothorax coccinarum. Hunt \& Lucas (1990) overlooked Sawin's (1947) separation

743 of the material when they reassigned all of the material to Longosuchus meadei. Separated out

744 again by Long \& Murry (1995), the presence of two distinct taxa was disputed by some workers

745 (e.g., Heckert \& Lucas, 1999, 2000) until Parker \& Martz (2010) presented the differences in 746 greater detail (Heckert et al., 2015).

747 The holotype of Lucasuchus hunti is a single paramedian plate, but Long \& Murry (1995)

748 assigned numerous postcranial elements to the taxon. However, lack of preparation of much of

749 this material, questions regarding associated with apomorphic osteoderms, as well as apparent

750 similarities with Longosuchus meadei makes many of these referrals questionable. Nonetheless

751 there is still much unprepared material at the VPL that is almost certainly represents Lucasuchus

752 hunti. A recently prepared partial skull (TMM 31100-531) from Howard County, Texas differs

753 in some ways from the lectotype skull of Longosuchus meadei and could represent Lucasuchus

754 hunti (Martz \& Parker, unpublished data).

755 Osteoderms previously referred to Desmatosuchus and Longosuchus from the Pekin

756 Formation of North Carolina actually pertain to Lucasuchus providing an important

757 biostratigraphic correlation (Parker \& Martz, 2010; Heckert et al., 2015).

758 Key References - Long \& Murry, 1995; Parker \& Martz, 2010; Heckert et al., 2015.

759 Gorgetosuchus pekinensis Heckert, Schneider, Fraser, \& Webb 2015 
761 Holotype - NCSM 21723, a large portion of the cervical and anterior trunk carapace.

762 Referred Material - none.

763 Age - Late Triassic,?Carnian, Otischalkian (Huber, Lucas \& Hunt, 1993).

764 Occurrence - Upper portion of the Pekin Formation, Newark Supergroup, North Carolina,

765 U.S.A. (Heckert et al., 2015).

766 Remarks - The holotype of Gorgetosuchus pekinensis (NCSM 21723) consists solely of the

767 anterior portion of the trunk carapace of a desmatosuchine aetosaur. Similar in overall anatomy

768 to Longosuchus meadei and Lucasuchus hunti, Gorgetosuchus pekinensis differs from these two

769 taxa, and all other desmatosuchines, mainly in the possession of cervical paramedian osteoderms

770 that are wider than long.

771 Key References - Schneider, Heckert \& Fraser, 2011; Heckert et al., 2015.

772

773

774

775

776

777

778

779

780

781

782

783

\section{Neoaetosauroides engaeus Bonaparte 1969}

Holotype - PVL 3525, lower jaw and postcranial skeleton (Bonaparte, 1969).

Referred Material - see Desojo \& Báez (2007).

Age - Late Triassic, middle Norian, early Revueltian (Martinez et al., 2013; Kent et al., 2014).

Occurrence - Upper part of the Los Colorados Formation, Argentina (Desojo \& Báez, 2005).

Lucas (1998a) considered the Los Colorados Formation equivalent to his Apachean 'Land

Vertebrate Faunachron' and therefore Rhaetian, or at least latest Norian, based on the presence of sauropodomorph dinosaurs and crocodyliform pseudosuchians. However, recent reexamination of strata in the Ischigualasto Basin, including a detailed paleomagnetic study, suggests instead that the vertebrate bearing portion of the Los Colorados may in fact be equivalent to the upper 
784 portion of the Sonsela Member of the Chinle Formation and thus Revueltian in age (Martinez et 785 al., 2013; Kent et al., 2014).

786 Remarks - The holotype of Neoaetosauroides engaeus was diagnosed by Bonaparte (1969) and

787 first described in detail by Bonaparte (1972). Poorly understood for the purpose of prior

788 phylogenetic analyses, the holotype and several referred skulls were recently redescribed by

789 Desojo \& Báez $(2005,2007)$. Heckert \& Lucas (2000) considered the paramedian osteoderms to

790 be almost completely devoid of ornamentation and this lack of ornamentation to be an

791 autapomorphy of the taxon. However, personal examination of the type specimens shows that

792 Neoaetosauroides engaeus possesses a clear radial ornamentation of the dorsal osteoderms (also

793 see Desojo \& Báez, 2005). Indeed, the ornamentation is indistinguishable from that of the

794 Ischigualasto taxon Aetosauroides scagliai. Portions of the holotype carapace are devoid of

795 ornamentation, but this is clearly the result of overpreparation of the material. Nonetheless, three

796 small osteoderms from the Redonda Formation (Dockum Group) of New Mexico were assigned

797 to Neoaetosauroides based upon a lack of distinct ornamentation (Heckert et al., 2001). These

798 osteoderms subsequently became the holotype of a new taxon Apachesuchus heckerti

799 (Spielmann \& Lucas, 2012). Character state scorings for Neoaetosauroides engaeus are from the 800 type and referred materials.

801 Key References - Bonaparte, 1969, 1972; Desojo \& Báez, 2005, 2007.

802

803 Paratypothorax andressorum Long \& Ballew 1985

804

805 Holotype-SMNS unnumbered, left trunk paramedian osteoderm (labeled L18 on red sticker)

806 (Long \& Ballew, 1985). 
807 Paratypes - SMNS unnumbered, partial disarticulated carapace that includes the holotype

808 osteoderm.

809 Referred Material - NHMUK R38070, posterior trunk vertebra (Meyer, 1865:pl. XXVII, figs. 1-

810 3); NHMUK R38083, left trunk paramedian osteoderm; NHMUK R38085, partial right trunk

811 paramedian osteoderm (Meyer, 1865:pl. XXVIII, figs. 4-6); NHMUK R38086, partial right

812 paramedian osteoderm; NHMUK R38087, pathologic left mid-caudal paramedian osteoderm

813 (Meyer, 1865:pl. XXVIII, figs. 7-9; NHMUK R38090, right trunk paramedian osteoderm, partial

814 left trunk paramedian osteoderm, three partial right paramedian osteoderms, partial left lateral

815 osteoderm, left lateral osteoderm, two partial paramedian osteoderms; SMNS 3285, partial

816 paramedian osteoderm; SMNS 2958, three pathologic paramedian osteoderms (Lucas, 2000);

817 SMNS 4345 left trunk lateral osteoderm; SMNS 4386, right trunk lateral osteoderm (Meyer,

818 1861: pl. XLIII, fig. 1). ; SMNS 5721 right paramedian osteoderm (Meyer, 1865: P1. XXVIII,

819 figs. 1-3); YPM 3694, right trunk lateral osteoderm (Gregory, 1953b).

820 Age - Late Triassic, Norian, Revueltian (Deutsche Stratigraphische Kommission, 2005; Lucas, $8212010)$.

822 Occurrence - Lower Stubensandstein, Löwenstein Formation, Baden-Württemberg, Germany 823 (Long \& Ballew, 1985).

824 Remarks - The SMNS collections possess numerous osteoderms including much of what appears 825 to be a carapace of a single individual that have had a confusing taxonomic history. The 826 osteoderms were collected with and considered to belong to the phytosaur Nicrosaurus

827 (=Belodon $=$ Phytosaurus) until the mid-1980s (Long \& Ballew, 1985). This belief caused

828 significant confusion regarding the taxonomy of phytosaur and aetosaur material (Case, 1932;

829 Gregory, 1962; Gregory \& Westphal, 1969). The issue was finally sorted out when Long \& 
830 Ballew (1985) recognized that all of the broad rectangular osteoderms belonged to aetosaurs and

831 coined the name Paratypothorax addressorum for the German osteoderms originally assigned to

832 Nicrosaurus. The species epithet was correctly amended to Paratypothorax andressorum by

833 Lucas \& Heckert (1996) as the species was originally named in honor of the Andress family

834 (Chris Andress was Chief Ranger at Petrified Forest National Park in 1985). Long \& Ballew

835 (1985) also noted material from southwestern North America that is referable to Paratypothorax

836 although they were unsure that it represented the same species as the European material. This has

837 led to two views regarding the assignment of the North American material; 1) that it is referable

838 to Paratypothorax andressorum (Hunt \& Lucas, 1992; Heckert \& Lucas, 2000; Lucas, Heckert

839 \& Rinehart, 2006), or that it may represent a new taxon (Long \& Ballew, 1985; Long \& Murry,

840 1995). This is not yet resolved so they are treated here as two distinct taxa.

841 The German material has never actually been fully described and the present concept of

842 Paratypothorax (sensu Long \& Murry, 1995) is actually based on the referred North American

843 material. There is also some confusion regarding the type specimens of Paratypothorax

844 andressorum, with some workers treating a well-preserved carapace (SMNS unnumbered) as the

845 holotype or as a syntype series for the taxon (e.g., Hunt \& Lucas, 1992, Lucas, Heckert \&

846 Rinehart, 2006). However, Long \& Ballew (1985:57) clearly identify a single osteoderm as the

847 holotype so the other osteoderms in this specimen can be no more than paratypes (Heckert \&

848 Lucas, 2000).

849 An impression of a partial dorsal paramedian osteoderm (MCZ field No. 23/92G) from

850 Greenland was assigned to Paratypothorax andressorum (Jenkins et al., 1994). Although the

851 specimen clearly possesses a raised anterior bar, radial pattern of pits and grooves, a dorsal

852 eminence that contacts the posterior osteoderm margin, characteristic for paratypothoracins, the 
853 beveled posterior edge delineated by a distinct ridge is not a clear autapomorphy of

854 Paratypothorax andressorum and thus this specimen should instead be assigned to

855 Paratypothoracini (Martz \& Small, 2006; Desojo et al., 2013). I have not examined the other

856 three osteoderms mentioned by Jenkins et al. (1994) and assigned to Paratypothorax

857 andressorum.

858 Key References - Long \& Ballew, 1985.

859

860 Paratypothorax sp.

861

862

Referred Material - PEFO 3004, associated osteoderms and vertebrae from the posterior dorsal

863 and anterior caudal regions (Long \& Murry, 1995); FMNH PR1610, partial paramedian

864 osteoderm (same specimen as PEFO 3004); DMNH 9942; partial postcranial skeleton (Long \&

865 Murry, 1995); VRPH2, numerous paramedian and lateral osteoderms; see Martz et al. (2013) for

866 additional specimens.

867 Age - Late Triassic, Adamanian-Revueltian, mid-Norian (Ramezani et al., 2011; Parker \&

868 Martz, 2011).

869 Occurrence - Chinle Formation, Arizona and New Mexico, U.S.A.; Dockum Group, Texas,

870 U.S.A (Long \& Murry, 1995; Parker \& Martz, 2011; Martz et al., 2013).

871 Remarks - the presence of Paratypothorax material in North America was first recognized by

872 Long \& Ballew (1985) although they were unsure of its exact relationship with the German

873 material, which they named Paratypothorax andressorum. Since that time numerous specimens

874 referable to Paratypothorax sp. or Paratypothoracini have been collected from the Upper Triassic

875 Chinle Formation and Dockum Group (see Long \& Murry, 1995; Parker \& Martz, 2011; Martz 
876 et al., 2013 for lists). This material includes lateral osteoderms from the Placerias Quarry of

877 Arizona that were originally identified by Long \& Ballew (1985) as cervical laterals of

878 Calyptosuchus wellesi (Parker, 2005a). The best preserved specimen of Paratypothorax sp.

879 (PEFO 3004) is an associated set of posterior trunk and anterior caudal osteoderms and vertebrae 880 of a single individual from the Chinle Formation of Arizona. First mentioned by Long \& Ballew

881 (1985), but described by Hunt \& Lucas (1992), the latter authors assigned PEFO 3004 to

882 Paratypothorax andressorum. This assignment was followed by Heckert \& Lucas (2000) and

883 Lucas, Heckert \& Rinehart (2006). However, differences between the North American and

884 European material were noted by Long \& Murry (1995) based on a specimen from the Dockum

885 Group of Texas (DMNH 9942). Therefore the North American material is treated separately for 886 this study. Paratypothorax sp. is known almost solely from osteoderms and vertebrae (Hunt \&

887 Lucas, 1992; Long \& Murry, 1995). However, DMNH 9942 contains some forelimb material

888 (Long \& Murry, 1995). Long \& Murry (1995) also questionably referred an ilium from the Post

889 Quarry of Texas to the taxon, but this assignment is ambiguous. Martz et al. (2013) figure a

890 fibula (TTU P-09416) they assign to Paratypothorax sp. A dentary of Paratypothorax was

891 mentioned by Small (1989); however, the specimen is now considered to be a lateral osteoderm

892 (Martz et al., 2013). It is possible that cranial material referred by Small (2002) to

893 Desmatosuchus actually represents Paratypothorax sp. (Martz et al., 2013), but this has not yet

894 been fully demonstrated.

895 Key References - Hunt \& Lucas, 1992; Small, 1989; Long \& Ballew, 1985; Long \& Murry, 896 1995; Martz et al., 2013.

897 
898 Polesinesuchus aurelioi Roberto-Da-Silva, Desojo, Cabriera et al. 2014

899 Holotype-ULBRA PVT003, parietal and braincase fragments, much of a postcranial skeleton

900 (Roberto-da-Silva et al., 2014).

901

902 Age - Late Triassic, late Carnian - earliest Norian, Hyperodapedon Assemblage Zone (Langer et

903 al., 2007; Martinez et al., 2011).

904 Occurrence - Sequence 2, Santa Maria supersequence, Rio Grande Do Sul, Brazil (Desojo, 905 Ezcurra \& Kischlat, 2012).

906

907

908

909

910

911

912

913

914

915

916

917

918

919

920

921

922

Remarks - Polesinesuchus aurelioi was erected for mainly the endoskeletal material of a skeletally immature aetosaurian from the Upper Triassic of Brazil (Roberto-da-Silva et al., 2014). The taxon was not diagnosed by any recognized autapomorphies, but rather from a unique combination of characters that differentiates it from all known South American aetosaurians.

Overall the material is most similar to that of Aetosauroides scagliai, but lacks the deep lateral fossae found in the cervical and dorsal vertebrae of that taxon. The vertebrae of Polesinesaurus aurelioi are notable in that they appear to lack vertebral laminae, which may be an autapomorphy of the taxon. However, the laterally expansive prezygapophyses listed as a defining character of the taxon may actually represent prezygadiapophyseal laminae (sensu Wilson, 1999), as these laminae form a similar structure in the presacral vertebrae of Scutarx deltatylus (PEFO 31217 ). The skeletally immature status of the material is problematic because our present understanding of character variation and transformation through ontogeny is poor and these unique characteristics may simply be the result of the ontogenetic immaturity at time of death. Indeed, Polosinesuchus aurelioi appears to represent the well-preserved, but relatively unremarkable remains of a skeletal immature aetosaurian. Future histological studies of this taxon and others across will provide needed information on the timing of the appearance of key osteological landmarks in aetosaurian clades. 
923 A recent phylogenetic analysis recovered Polesinesuchus as the sister taxon to

924 Aetobarbakinoides in a clade that is sister taxon to Desmatosuchinae plus Typothoracinae, but

925 this could be an artifact of missing data, especially from the paramedian and lateral osteoderms

926 (Roberto-da-Silva et al., 2014).

927 Key Reference - Roberto-da-Silva et al., 2014.

928

\section{Postosuchus kirkpatricki Chatterjee 1985}

930 Holotype - TTU P-9000, almost complete skull and partial skeleton (Chatterjee, 1985).

931 Paratype - TTU P-9002, almost complete skull and partial skeleton (Chatterjee, 1985).

932 Age - Late Triassic, early to middle Norian, Adamanian (Martz et al., 2013).

933 Occurrence - Cooper Canyon Formation, Dockum Group, Texas, U.S.A (Martz et al., 2013).

934 Remarks - Postosuchus kirkpatricki is a well-known rauisuchid archosaur represented by

935 excellent material from the Post Quarry of Texas. The type materials were recently redescribed

936 in detail by Weinbaum $(2011,2013)$. Technically because the species was named in honor of the

937 Kirkpatrick family (Chatterjee, 1985), the species epithet should be Postosuchus

938 kirkpatrickorum; however, an emendation was never made and the present version (4 ${ }^{\text {th }}$ Edition)

939 of the International Code of Zoological Nomenclature no longer requires that such emendations

940 be made (ICZN, 1999).

941 Key References - Chatterjee, 1985; Nesbitt, 2011; Weinbaum, 2011, 2013.

942

943 Redondasuchus rinehardti Spielmann, Hunt, Lucas, \& Heckert 2006

944

945 Holotype - NMMNH P-43312, partial right dorsal paramedian osteoderm (Spielmann et al., 946 2006). 
947 Referred Material - see Spielmann et al., 2006. With permission, unpublished material currently

948 under study by Jeffrey Martz and Axel Hungerbühler at Mesalands Dinosaur Museum in

949 Tucumcari, New Mexico is also scored.

950 Age - Late Triassic, late Norian to Rhaetian, Apachean (Spielmann \& Lucas, 2012).

951 Occurrence - Redonda Formation, Dockum Group, New Mexico, U.S.A (Spielmann \& Lucas, 952 2012).

953 Remarks - A fair amount of aetosaurian osteoderm material has been recovered from the Upper

954 Triassic Redonda Formation of New Mexico, most of which appears to be from at least one

955 typothoracine. Redondasuchus reseri was named by Hunt \& Lucas (1991) for a small

956 typothoracine aetosaurs that reportedly lacked lateral osteoderms, and instead proposed a novel

957 reconstruction for an aetosaurian in which the flexed outer edge of the trunk paramedians

958 covered the flank of the animal rather than a separate laterally situated osteoderm (Heckert, Hunt

$959 \&$ Lucas, 1996). However, the holotype trunk osteoderm was interpreted backwards by those

960 authors with the flexed 'outer edge' actually being situated along the midline of the carapace.

961 Moreover, there is no direct evidence that Redondasuchus reseri differed from all other aetosaurs

962 in lacking lateral osteoderms (Martz, 2002).

963 Martz (2002) could not distinguish the osteoderms of Redondasuchus reseri from those

964 of Typothorax coccinarum in any characteristic other than size, but Spielmann et al. (2006)

965 argued that Redondasuchus reseri was indeed distinct and named a second species,

966 Redondasuchus rineharti, for isolated osteoderms and a proximal femur head from a larger

967 aetosaurian. Those authors differentiated the new species from Redondasuchus reseri based on

968 larger size and the presence of a dorsal eminence on the paramedian osteoderms. Differentiation

969 based on size is problematic as no ontogenetic study has been made for Redondasuchus to refute 
970 the idea that the holotype and referred specimens of Redondasuchus reseri are simply skeletally

971 immature specimens of another typothoracine. Moreover, in Typothorax coccinarum, the more

972 anterior dorsal paramedian osteoderms lack dorsal eminences. Furthermore, strong flexion of

973 paramedian osteoderms occurs in several aetosaur taxa including Typothorax coccinarum (PEFO

974 23388), Paratypothorax sp. (PEFO 3004), Sierritasuchus macalpini (UMMP V60817), and

975 Calyptosuchus wellesi (UCMP 136744). Thus Redondasuchus reseri lacks clear autapomorphies

976 or even a unique combination of characters and it is not included in this study pending future

977 reexamination. However, there are some fundamental differences between Redondasuchus

978 rineharti and Typothorax coccinarum including the more closely packed and deep pits in

979 Redondasuchus rineharti, as well as the oblong pits in the transverse trough posterior to the

980 anterior bar and it is included in the present analysis, supplemented by scorings from new

981 undescribed material from New Mexico (J. Martz, pers. comm. 2013).

982 Key References - Spielmann et al., 2006; Spielmann \& Lucas, 2012.

983

984 Revueltosaurus callenderi Hunt 1989

985

986

Holotype - NMMNH P-4957, nearly complete premaxillary tooth.

987 Referred Material - PEFO 33787, partial skeleton and skull; PEFO 33788, partial skull; PEFO

988 34269, partial skeleton and skull; PEFO 34561, nearly complete skeleton and skull; PEFO

989 36875, nearly complete skeleton and skull; PEFO 36876, partial skeleton and skull (Parker \&

990 Martz, 2011; Nesbitt, 2011; Parker et al., 2005, 2007, in prep).

991 Age - Late Triassic, mid to late Norian, Revueltian (Ramezani et al., 2011; Parker \& Martz, 992 2011). 
993 Occurrence - Petrified Forest Member, Chinle Formation, Arizona, U.S.A.; Bull Canyon

994 Formation, Dockum Group, New Mexico, U.S.A (Hunt, 1989; Parker et al., 2005).

995 Remarks - Originally known from only isolated teeth that were assigned to ornithischian

996 dinosaurs (Hunt, 1989; Padian, 1990; Heckert, 2003), Revueltosaurus callenderi is currently one

997 of the most completely documented pseudosuchians based on an as of yet undescribed series of

998 skeletons recovered from the Chinle Formation of Petrified Forest National Park in Arizona

999 (Parker et al., 2005, 2007; Nesbitt, 2011; Farlow et al. 2014). A current phylogenetic analysis of

1000 the Archosauriformes recovers Revueltosaurus callenderi as the sister taxon of Aetosauria

1001 (Nesbitt, 2011).

1002 Key References - Heckert, 2003; Parker et al., 2005, 2007; Nesbitt, 2011.

1003

1004 Rioarribasuchus chamaensis (Zeigler, Heckert \& Lucas 2003)

1005

1006

Holotype - NMMNH P-32793, right anterior caudal paramedian osteoderm (Zeigler et al., 2003).

1007

1008 Referred Material - see Parker, 2007.

1009 Age - Late Triassic, mid-late Norian, Revueltian (Irmis et al., 2011).

1010 Occurrence - Petrified Forest Member, Chinle Formation, New Mexico, U.S.A.; Martha’s Butte

1011 beds, Sonsela Member, Chinle Formation, Arizona, U.S.A (Zeigler, Heckert \& Lucas, 2003;

1012 Parker \& Martz, 2011).

1013 Remarks - Rioarribasuchus chamaensis was first described as a new species of Desmatosuchus

1014 by Zeigler, Heckert \& Lucas (2003) based on isolated paramedian and lateral osteoderms from

1015 the Revueltian Snyder Quarry in New Mexico. Parker (2003) demonstrated with a phylogenetic 
1016 analysis that "Desmatosuchus" chamaensis was closer to Paratypothorax rather than

1017 Desmatosuchus, a finding opposed by Heckert, Zeigler \& Lucas (2003) who argued that the

1018 taxon was more like Desmatosuchus than Paratypothorax. Parker \& Irmis (2005) and Parker

1019 (2006) reiterated that "Desmatosuchus" chamaensis should be assigned to a new genus, differing

1020 from studies such as Lucas et al. (2005) and Heckert, Lucas \& Hunt (2005) and Heckert et al.

1021 (2005) who continued to assign the species to the genus Desmatosuchus. Subsequently two

1022 names were coined for the taxon nearly simultaneously, Heliocanthus Parker 2007 and

1023 Rioarribasuchus Lucas, Hunt \& Spielmann 2006; however, the paper by Lucas, Hunt \&

1024 Spielmann, 2006 was published earlier and thus the name Rioarribasuchus has priority. The

1025 status of the taxonomic naming was considered controversial (e.g., Dalton, 2008), but was

1026 resolved by Irmis et al. (2007), who as first reviser, used the name Rioarribasuchus chamaensis

1027 and accordingly Heliocanthus is a junior objective synonym of Rioarribasuchus. The close

1028 relationship between Rioarribasuchus and Paratypothorax has been recovered by all current

1029 phylogenetic analyses of the Aetosauria (Parker, 2007; Desojo, Ezcurra \& Kischlat, 2012;

1030 Heckert et al., 2015). Indeed Rioarribasuchus chamaensis possesses no desmatosuchine

1031 apomorphies (Parker, 2007); however, some workers still consider Rioarribasuchus to be a

1032 desmatosuchine (e.g., Lichtig \& Lucas, 2014) although they have not supported this with a

1033 phylogenetic analysis.

1034 Parker (2007) also provided a novel reconstruction of Rioarribasuchus chamaensis in

1035 which the sacral and anterior caudal paramedian osteoderms possess dorsal eminences that have

1036 the form of an elongate, anterior medially directed, curved spine. The presence of these

1037 eminences is an autapomorphy of the taxon. The orientation and placement of the osteoderms

1038 with the spines was criticized by Lucas \& Connealy (2008) and Lichtig \& Lucas (2014); 
1039 however, orientation of the osteoderms using the anterior bar and the direction of osteoderm

1040 edge tapering demonstrates that the orientation proposed by Parker (2007) must be correct. The

1041 anterior paramedians and all of the lateral osteoderms are identical to Paratypothorax, and

1042 originally were thought to represent that taxon by the discoverers (Heckert \& Zeigler, 2003). The

1043 presence of lateral plates identical to paratypothoracin aetosaurians supports the hypothesis that

1044 the osteoderms with the elongate recurved spines must be paramedians and not laterals (Parker,

1045 2007; differing from Lucas \& Connealy; Lichtig \& Lucas, 2014). Rioarribasuchus chamaensis is

1046 currently known from the Snyder and Hayden quarries in the Chama Basin of New Mexico and

1047 from Petrified Forest National Park in Arizona. All three of these localities are in Revueltian

1048 strata of the Chinle Formation (Heckert et al., 2005; Irmis et al., 2007; Parker \& Martz, 2011).

1049 Rioarribasuchus chamaensis is currently known mainly from osteoderms, although

1050 Heckert, Zeigler \& Lucas (2003) referred two astragali (NMMNH P-33927, NMMNH P-33932)

1051 and a calcaneum (NMMNH P-33931) from the Snyder Quarry. Those authors did not list any

1052 apomorphies or provide any comparisons to other taxa for the astragali and thus this referral is

1053 ambiguous given the co-occurrence of Typothorax coccinarum in the quarry. However, they did

1054 note that the referred calcaneum is not as dorsoventrally compressed as the calcaneum of

1055 Typothorax coccinarum (presumably AMNH FR 2713). Unfortunately there are no recognized

1056 paratypothoracin distal tarsals to use for a comparison to help verify these assignments. An

1057 isolated anterior aetosaurian caudal vertebrae (GR 174) from the Hayden Quarry bears caudal

1058 ribs that originate close to the base of the centrum rather than at the base of the neural arch. This

1059 character only occurs in Paratypothorax sp. (PEFO 3004) and not in Typothorax (Martz, 2002)

1060 so the Hayden Quarry vertebra is assigned to Paratypothoracini, most likely Rioarribasuchus

1061 chamaensis. 
1062 Key References - Zeigler, Heckert \& Lucas, 2003; Heckert, Zeigler \& Lucas, 2003; Parker, 10632007.

1064

1065 Scutarx deltatylus gen et sp. nov.

Holotype - PEFO 34616, partial skull, cervical paramedian and lateral osteoderms.

1068

Zoobank LSID -- urn:lsid:zoobank.org:act:E06A8E11-5864-4717-AFA2-9021842B886D

1069

Referred Material - PEFO 31217, much of a postcranial skeleton including vertebrae, ribs,

1070

pectoral and pelvic girdles, osteoderms; PEFO 34919, much of a postcranial skeleton including

1071

vertebrae, ribs, osteoderms, ilium; PEFO 34045, much of a postcranial skeleton including

1072

vertebrae, ribs, and osteoderms; TTU P-09420, two paramedian osteoderms; UCMP 36656,

1073

paramedian and lateral osteoderms. The last two specimens were previously referred to

1074 Calyptosuchus wellesi (Martz et al., 2013).

1075 Age - Late Triassic, middle Norian, late Adamanian (Ramezani et al., 2011; Parker \& Martz,

1076 2011; Martz et al., 2013).

1077 Occurrence - lower part of the Sonsela Member, Chinle Formation, Arizona, U.S.A.; middle

1078 part of the Cooper Canyon Formation, Dockum Group, Texas, U.S.A (Parker \& Martz, 2011).

1079 Etymology -- Scutarx 'shield fortress,' from Latin scutum 'shield' + Latin arx 'fortress, castle;'

1080 deltatylus 'triangular protuberance,' from Greek delta + Greek tylos 'knob, knot, swelling,

1081 callous, protuberance.'

1082 Diagnosis - Medium-sized aetosaurian diagnosed by the following autapomorphies; the cervical

1083 and dorsal trunk paramedian osteoderms bear a strongly raised, triangular tuberosity in the

1084 posteromedial corner of the dorsal surface of the osteoderm (Figure 2); the occipital condyle 
1085 lacks a distinct neck because the condylar stalk is mediolaterally broad (Figure 3); the base of the

1086 cultriform process of the parabasisphenoid bears deep lateral fossae (parasphenoid recesses;

1087 Figures 3-4); the frontals and parietals are very thick dorsoventrally; and there is a distinct fossa

1088 or recess on the lateral surface of the ilium between the supraacetabular crest and the posterior

1089 portion of the iliac blade (Figure 5). Scutarx deltatylus can also be differentiated from other

1090 aetosaurs by a unique combination of characters including moderately wide dorsal trunk

1091 paramedian osteoderms with a strongly raised anterior bar that possesses anteromedial and

1092 anterolateral processes (shared with all aetosaurians except Desmatosuchini; Figure 2);

1093 osteoderm surface ornamentation of radiating ridges and pits that emanate from a posterior

1094 margin contacting a dorsal eminence (shared with Calyptosuchus wellesi, Stagonolepis

1095 robertsoni, Adamanasuchus eisenhardtae, Neoaetosauroides engaeus, Aetobarbakinoides

1096 brasiliensis, and Aetosauroides scagliai); lateral trunk osteoderms with an obtuse angle between

1097 the dorsal and lateral flanges (shared with non-desmatosuchines); a dorsoventrally short pubic

1098 apron with two proximally located 'obturator' fenestrae (shared with Stagonolepis robertsoni);

1099 and an extremely anteroposteriorly short parabasisphenoid, with basal tubera and basipterygoid

1100 processes almost in contact and a reduced cultriform process (Figure 3; shared with

1101 Desmatosuchus).

1102 Remarks - Aetosaurian material referable to Calyptosuchus occurs through Adamanian-age

1103 deposits in Arizona, New Mexico, and Texas. In Arizona, specimens from the Sonsela Member

1104 previously referred to Calyptosuchus wellesi (e.g., Long \& Murry, 1995; Parker \& Irmis, 2005;

1105 Parker, 2005a, 2006; Parker \& Martz, 2011; Martz et al., 2013) possess a distinctive raised

1106 triangular boss on the posteromedial corner of the dorsal surface of the paramedian osteoderms

1107 (Figure 2). Detailed comparison demonstrates that this character is not present in the holotype of 
1108 Calyptosuchus wellesi (UMMP 13950) or in referred material of that taxon from the Placerias

1109 Quarry. Thus this feature is autapomorphic of a new taxon, Scutarx deltatylus, which is named

1110 and diagnosed here, but will be fully described elsewhere. In this analysis, Scutarx deltatylus is

1111 coded from four new, partial skeletons from Petrified Forest National Park in Arizona. Newly

1112 recognized osteoderms of Calyptosuchus (TTU P-09420) from the Post Quarry of Texas also

1113 possess the diagnostic triangular boss and thus are actually referable to Scutarx deltatylus and not

1114 Calyptosuchus wellesi (differing from the interpretation by Martz et al., 2013). This occurrence

1115 supports correlation of the Post Quarry (middle Cooper Canyon Formation) to the lower part of

1116 the Sonsela Member of Arizona as suggested by Martz et al. (2013). Thus is may be possible to

1117 subdivide the Adamanian biozone utilizing Calyptosuchus and Scutarx.

1118 Key References - Parker, 2014; Parker \& Irmis, 2005; Martz et al., 2013.

1119

1120 Sierritasuchus macalpini Parker, Stocker \& Irmis 2008

1121

1122

Holotype - UMMP V60817, partial postcranial skeleton consisting of vertebrae and osteoderms

1123 (Parker, Stocker \& Irmis, 2008).

1124 Referred Material - TTU P-10731, left lateral osteoderm.

1125 Age - Late Triassic, early to mid-Norian, Adamanian (Ramezani et al., 2011; Lucas, 2010).

1126 Occurrence - Tecovas Formation, Dockum Group, Texas, U.S.A (Long \& Murry, 1995; Parker,

1127 Stocker \& Irmis, 2008).

1128 Remarks - The holotype (UMMP V60817) of Sierritasuchus macalpini was collected in 1939

1129 from the Tecovas Formation of Texas by the late Archie J. MacAlpin (University of Notre

1130 Dame), who at the time was a student of Ermine C. Case of the University of Michigan. The 
1131 specimen, which consists of vertebrae and osteoderms from the cervical and dorsal regions, was

1132 originally referred to Desmatosuchus haplocerus by Long \& Murry (1995). Parker (2002)

1133 questioned this referral and considered the possibility that UMMP V60817 represented a

1134 skeletally immature specimen of Longosuchus meadei even though it was from a higher

1135 stratigraphic position.

1136 Redescribed by Parker, Stocker \& Irmis (2008), this was the first aetosaurian specimen to

1137 have osteoderms histologically sampled to help determine the ontogenetic stage of the specimen.

1138 Histological analysis suggested that although it is not a full grown adult, the preserved material

1139 has no indicators of skeletal immaturity either (Parker, Stocker \& Irmis, 2008). Within

1140 Desmatosuchinae Sierritasuchus macalpini shares more characters with Longosuchus meadei

1141 than Desmatosuchus spurensis, but differs from the former in possessing dorsoventrally

1142 flattened, non- faceted, recurved spines on the lateral osteoderms. Parker, Stocker \& Irmis (2008)

1143 listed an additional difference, the lack of radial pattern on the dorsal paramedian osteoderms,

1144 but subsequent examination of the type materials of Longosuchus meadei demonstrate a random

1145 not radial pattern (Parker \& Martz, 2010). Longosuchus meadei was scored as having a radial

1146 pattern in existing phylogenetic analyses (Heckert, Hunt \& Lucas, 1996; Heckert \& Lucas,

1147 1999), and this scoring was repeated in subsequent analyses (Parker, 2007; Parker, Stocker \&

1148 Irmis, 2008). Determining the exact position of Sierritasuchus macalpini within

1149 Desmatosuchinae has been problematic (Parker, 2007; Parker, Stocker \& Irmis, 2008); but

1150 Desojo, Ezcurra \& Kischlat (2012) recovered Sierritasuchus macalpini as the earliest branching

1151 member of the Desmatosuchinae.

1152 Key References - Parker, Stocker \& Irmis, 2008; Desojo, Ezcurra \& Kischlat, 2012. 


\section{Unnamed taxon SMNS 19003}

1155

1156

1157 2010).

1158 Occurrence - Lower and middle Stubensandstein, Löwenstein Formation, Germany (Desojo et

1159 al., 2013).

1160 Remarks - SMNS 19003 represents an almost complete, articulated skeleton of a

1161 paratypothoracin aetosaur from the Upper Triassic of Germany. The specimen includes a

1162 beautifully preserved skull, which is the only unambiguous, non-braincase skull material known

1163 for a paratypothoracin. Desojo et al. (2013) refer the specimen as Paratypothorax andressorum,

1164 but the material has yet to be described and is currently under study by Rainer Schoch and Julia

1165 Desojo (Desojo \& Schoch, 2014). However, some details of the skull were presented by Sulej

1166 (2010). One notable characteristic of the skull is that the apex of the premaxilla lacks the

1167 transverse expansion found in aetosaurs such as Desmatosuchus and Stagonolepis (Desojo \&

1168 Schoch, 2014). Typothorax coccinarum (PEFO 38001/YPM 58121) also lacks this expansion,

1169 suggesting that this may be an apomorphy for Typothoracinae.

1170 Key References - Sulej, 2010; Desojo et al., 2013; Desojo \& Schoch, 2014.

1171

\section{Stagonolepis robertsoni Agassiz 1844}

1173

1174

1175

Holotype - EM 27 R, impression of a segment of the plastron (Agassiz, 1844).

Referred Material - see Walker (1961) for a full list; particularly important is MCZD 2, an

1176 articulated partial skeleton including much of the skull with a well preserved braincase and 1177 articulated nuchal and cervical paramedian osteoderms. 
1178 Age - Late Triassic, ?Carnian (Lucas, 2010).

1179 Occurrence - Lossiemouth Sandstone Formation, Scotland, U.K (Walker, 1961).

1180 Remarks - Originally described by Agassiz (1844) as a fish from what was thought to be the Old

1181 Red Sandstone in Scotland, Charles Lyell first raised suspicions that Stagonolepis might instead

1182 be a reptile more closely related to Mystriosuchus (Huxley, 1859). Reexamination the material

1183 showed it to be a parasuchian reptile and provided the first solid evidence that the Lossiemouth

1184 Sandstone Formation was Triassic in age (Huxley, 1859, 1875, 1877). Unfortunately much of the

1185 collected material consists of natural molds, which has made study of the specimens difficult and

1186 only possible through the making of casts (Huxley, 1859, 1877). Stagonolepis robertsoni was

1187 fully described by Walker (1961) who developed a new technique of creating flexible PVC casts

1188 to recover additional details from the deeper portions of the molds than was available to Huxley.

1189 Walker (1961) also had the benefit of new specimens, most importantly an actually articulated

1190 body fossil (MCZD 2), which represents a nearly complete skull and the anterior cervical armor

1191 (Walker, 1961; Gower \& Walker, 2002). This specimen allowed for detailed reconstruction of

1192 the skull and braincase and demonstrated clearly that Stagonolepis robertsoni was an aetosaurian

1193 rather than a phytosaur as previously believed (e.g., Camp, 1930).

1194 Although Walker's (1961) reconstruction of Stagonolepis robertsoni relied significantly

1195 on observations made from Aetosaurus ferratus, examination of the MCZD specimen and the

1196 NHMUK casts show that Walker's work is extremely reliable for comparisons; however,

1197 character scorings for this analysis are taken from the fossils and casts, not from the published

1198 reconstruction. This, of course, is based on the assumption that only a single taxon is present in

1199 the Scottish quarries. Walker did note the presence of two different size categories in the

1200 specimens, but determined any anatomical differences between the two to represent sexual 
1201 dimorphism. There is currently no evidence to refute this hypothesis, the most notable difference

1202 is in the coverage of ornamentation on the dorsal paramedian osteoderms where in the smaller

1203 individuals the posterior portions of the dorsal surfaces are devoid of any ornamentation.

1204 Unfortunately all of the quarries where all of the Stagonolepis robertsoni material originates

1205 have been closed and grown over, and it is unlikely that more material of Stagonolepis

1206 robertsoni will be found in the immediate future.

1207 What is clear from examination of the Scottish material is that Stagonolepis robertsoni is

1208 anatomically distinct from Calyptosuchus from North America, and Aetosauroides scagliai from

1209 South America (Parker \& Martz, 2011; Desojo \& Ezcurra, 2011; differing from Lucas \&

1210 Heckert, 2001 and Heckert \& Lucas, 2002). Although all share a basic radial patterning and a

1211 medially offset dorsal eminence, there are key differences in the osteoderms and especially in the

1212 cranial material of these taxa. Therefore all three are treated as separate terminal taxa in this

1213 analysis.

1214 Key References - Huxley, 1877; Walker, 1961; Gower \& Walker, 2002.

1215

1216 Stagonolepis olenkae Sulej 2010

1217

1218 Holotype-ZPAL AbIII/466/17, skull roof (Sulej, 2010).

1219 Referred Material - see Sulej (2010).

1220 Age - Late Triassic, late Carnian (Dzik \& Sulej, 2007).

1221 Occurrence - Drawno beds, Krasiejów, Opole Silesia, Poland (Sulej, 2010).

1222 Remarks - Stagonolepis olenkae was described by Sulej (2010) for remarkably well preserved

1223 aetosaur material from the Krasiejów quarry in Poland (Dzik, 2001; Dzik \& Sulej, 2007). The 
1224 original description of the holotype (Sulej, 2010) is based mainly on the skull material;

1225 unfortunately much of the descriptive text is identical to that of Walker (1961) so it is not clear if

1226 the Polish material is accurately described. Sulej (2010) provides some obscure references to

1227 postcranial material (e.g., mentioning of a tibia in the diagnosis), but other than some of this

1228 material being mentioned and partly figured by Dzik (2001), Lucas, Spielmann \& Hunt (2007)

1229 have provided the only descriptions and photographs of this material, but assigned it to

1230 Stagonolepis robertsoni based mainly on the ornamentation of the dorsal paramedian

1231 osteoderms. The most recent discussion of this material suggests that characters used to

1232 differentiate Stagonolepis olenkae from Stagonolepis robertsoni are polymorphic and S. olenkae

1233 is simply a variant of S. robertsoni (Antczak, 2015). This hypothesis is tested phylogenetically

1234 here for the first time.

1235 Key References - Sulej, 2010; Lucas, Spielmann \& Hunt 2007; Antczak, 2015.

1236

\section{Stenomyti huangae Small \& Martz 2013}

1238

1239

1240

1241

1242

1243 Age - Late Triassic, middle - late Norian, Revueltian (Ramezani et al., 2011; Small \& Martz, 1244 2013).

1245 Occurrence - red siltstone member, Chinle Formation, Eagle County, Colorado (Small \& Martz, 1246 2013). 
1247 Remarks - Stenomyti huangae is a well-documented small aetosaurian that, when originally

1248 discovered, was presented as the first good evidence for the presence of Aetosaurus in western

1249 North America (Small, 1998). Subsequent preparation and study revealed that it was

1250 anatomically distinct (Small \& Martz, 2013). Stenomyti huangae possesses a unique ventral

1251 armor arrangement, which instead of rows of articulated square osteoderms, consists of an

1252 arrangement of oval and irregularly shaped osteoderms that do not contact each other. The

1253 removal of these specimens from the genus Aetosaurus eliminates a proposed biochronological

1254 correlation between Europe and eastern North America, with western North America (Lucas,

1255 Heckert \& Huber, 1998).

1256 Key References - Small, 1998; Small \& Martz, 2013.

1257

1258 Tecovasuchus chatterjeei Martz \& Small 2006

1259

1260

Holotype - TTU P-00545, paramedian and lateral osteoderms of the trunk region, braincase,

1261 partial vertebra (Martz \& Small, 2006).

1262 Referred Material - UMMP 9600, right trunk paramedian osteoderm; TTU P-09222, left trunk

1263 paramedian osteoderm; TTU P-07244, trunk paramedian osteoderm; NMMNH P-25641, left (?)

1264 trunk lateral osteoderm; TMM 31173-54, partial left paramedian osteoderm; PEFO 37871,

1265 partial paramedian osteoderm; MNA V3202, partial right paramedian osteoderm, three right

1266 trunk lateral osteoderms, one ?left trunk lateral osteoderm fragment (Parker, 2005a); MNA

1267 V3000, left trunk lateral osteoderm; MNA V2898, left trunk lateral osteoderm (Heckert et al., 1268 2007).

1269 Age - Late Triassic, early to middle Norian, Adamanian (Lucas, 2010). 
1270 Occurrence - Tecovas Formation, Dockum Group, Texas, U.S.A.; ?Bluewater Creek Member,

1271 Chinle Formation, New Mexico, U.S.A.; upper Blue Mesa Member, Chinle Formation, Arizona,

1272 U.S.A (Parker, 2005a; Martz \& Small, 2006; Heckert et al., 2007).

1273 Remarks - The holotype (TTU P-00545) was collected in the 1950s by Wann Langston Jr. from

1274 the Tecovas Formation near Potter County, Texas. A referred specimen (UMMP 9600) was

1275 collected near the same area in 1925 by William Buettner of the University of Michigan. TTU P-

127600545 was assigned to Typothorax coccinarum by Small (1985:8) and TTU P-00545, TTU P-

1277 09222, and UMMP 9600 were assigned to Paratypothorax sp. by Long and Murry (1995).

1278 Lucas, Heckert \& Hunt (1995) recognized the distinctness of the UMMP osteoderm, but

1279 hesitated to erect a new taxonomic name based on a single osteoderm and were apparently

1280 unaware of the Texas Tech specimen. The TTU material was later described under the name

1281 Tecovasuchus chatterjeei (Martz \& Small, 2006).

1282 Parker (2005a) and Heckert et al. (2007) referred material from the lower part of the

1283 Chinle Formation to Tecovasuchus, including MNA V3202, which had previously used as

1284 support for the presence of cervical spines in Calyptosuchus wellesi (Long \& Ballew, 1985;

1285 Long \& Murry, 1995). The lateral osteoderms of MNA V3202 possess apomorphies of

1286 Paratypothoracini most notably the greatly reduced triangular dorsal flange. The preserved

1287 paramedian osteoderm in MNA V3202 appears to have a high width/length ratio and the

1288 posterior edge is distinctly beveled, which is an autapomorphy of Tecovasuchus chatterjeei

1289 (Parker, 2005a; Martz \& Small, 2006). PEFO 37871 is a portion of a paramedian osteoderm that

1290 also preserves the beveled posterior edge and therefore represents another occurrence from the

1291 lower part of the Chinle Formation, in this case the upper Blue Mesa Member. Tecovasuchus

1292 chatterjeei has been postulated as an index taxon for the early Adamanian (Heckert et al., 2007). 
1293 These authors also assigned additional material from the NMMNH collections (Heckert et al.,

1294 2007:fig. 3) to Tecovasuchus; however, no apomorphies of that taxon are apparent in the

1295 published figures or listed in the text so those specimens are not included here.

1296 Key References - Lucas, Heckert \& Hunt, 1995; Parker, 2005a; Martz \& Small, 2006; Heckert et

1297 al., 2007.

1298

\section{Typothorax coccinarum Cope 1875}

1300

1301

Lectotype - USNM 2585, five paramedian osteoderm fragments.

1302 Referred Material - Numerous specimens, see Long \& Murry, 1995; Hunt, 2001; Martz, 2002;

1303 and Parker \& Martz, 2011 for lists. Notable referred specimens include AMNH FR 2709,

1304 paramedian osteoderms, left femur; AMNH FR 2710, right femur (probably same specimen as

1305 AMNH FR 2709); AMNH FR 2713, lateral osteoderms, right femur, left calcaneum, caudal

1306 vertebra (lectotype of Episcoposaurus horridus); NMMNH P- 56299, articulated carapace

1307 missing the skull; NMMNH P-12964, nearly complete skeleton with skull (mostly destroyed);

1308 TTU P-09214, osteoderms, vertebrae, braincase, dentary; UCMP 34227, numerous dorsal

1309 paramedian osteoderms; UCMP 34255, articulated tail, limb and girdle material; PEFO

1310 38001/YPM 58121, associated skeleton with complete skull; partial skeleton with skull (still in

1311 preparation).

1312 Age - Late Triassic, middle to late Norian, latest Adamanian and Revueltian (Ramezani et al., 1313 2011; Irmis et al., 2011). 
1315 Occurrence - Sonsela and Petrified Forest members, Chinle Formation, Arizona, U.S.A.; middle

1316 part of the Cooper Canyon Formation, Dockum Group, Texas, U.S.A.; Bull Canyon Formation,

1317 Dockum Group, New Mexico, U. S. A. (Long \& Ballew, 1985; Heckert et al., 2010; Parker \&

1318 Martz, 2011; Martz et al., 2013).

1319 Remarks - Fossils of Typothorax coccinarum are extremely common in Revueltian rocks across

1320 the southwestern United States, but despite the large amount of available material most

1321 specimens have only been superficially or not described. An exception is a nearly complete

1322 skeleton (NMMNH P-56299) described by Heckert et al. (2010), which provides key information

1323 on the lateral osteoderms and especially the ventral armor. Some of the best figured materials are

1324 from the Canjilon Quarry (Martz, 2002), which forms the basis of much of the description by

1325 Long \& Murry (1995) as well as our understanding of the taxon.

1326 Until recently the only known cranial material was a complete skull (NMMNH P-12964)

1327 from the Bull Canyon Formation (Dockum Group) of New Mexico. This skull was very

1328 preliminarily described by Hunt, Lucas \& Reser (1993) and later figured, but not described by

1329 Heckert et al. (2010). Unfortunately this specimen was badly damaged during molding and is

1330 currently only visible in a cast (NMMNH C-4638) that is on exhibit at the New Mexico Museum

1331 of Natural History and Science (Heckert et al., 2010:628). Fieldwork by Yale University in the

1332 Petrified Forest Member (Chinle Formation) of Petrified Forest National Park in the summer of

13332008 resulted in the discovery of two skeletons of Typothorax coccinarum both which include

1334 well-preserved skulls. One of these skulls (PEFO 38001/YPM 58121) was used to code

1335 Typothorax for this study, but unfortunately the braincase is not exposed in that specimen. The

1336 second skull is still in preparation (M. Fox, pers. comm., 2014). 

paramedian osteoderms and most descriptions and referrals have been made using better preserved material such as AMNH FR 2709, AMNH FR 2710, or UCMP 34227. The type

1340 material is not diagnostic above the level of Typothoracinae and accordingly Typothorax 1341 coccinarum is most likely a nomen dubium (Parker, 2013).

1342 Note that, following discussion by Parker (2006), Parker \& Martz (2011), and Martz et al.

1343 (2013) Typothorax antiquum Lucas, Heckert \& Hunt, 2003 is not considered to be a valid taxon

1344 in this study, but rather a less skeletally mature specimen of Typothorax coccinarum. The

1345 occurrence (NMMNH P-25745) of the Revueltian index taxon Machaeroprosopus

1346 (=Pseudopalatus) at the type locality for Typothorax antiquum also necessitates a detailed review

1347 of the stratigraphic position of this material, which is purportedly Adamanian in age (Lucas,

1348 Heckert \& Hunt, 2003; Hunt, Lucas \& Heckert, 2005).

1349 Key References - Cope, 1875, 1877, 1887; Long \& Ballew, 1985; Long \& Murry, 1995; Martz, 1350 2002; Heckert et al., 2010; Parker, 2013.

\section{PHYLOGENETIC ANALYSIS}

The character matrix of 28 taxa and 83 characters (Appendices A and B) was assembled and edited in Morphobank (O’Leary \& Kaufman 2012) as matrix number 2617 of project number 1009, and exported as a NEXUS file (Appendix A). Submatrices (partitions) were edited

1356 using NEXUS Data Editor for Windows version 5.0 (Page, 2001). All matrices were analyzed in

1357 PAUP* (Version 4.0b10 for 32-bit Microsoft Windows, Swofford, 2003). Postosuchus

1358 kirkpatricki was constrained as the outgroup for the analysis. Revueltosaurus callenderi was

1359 utilized as a second outgroup, but unconstrained. 
1361 were excluded a priori to eliminate inflation of tree C.I. values (Kitching et al., 1998). The final

1362 matrix consists of 52 binary and 28 multi-state characters ten of which were treated as ordered if

1363 they were judged to form a morphocline (Slowinski, 1993).

1364 Branches were set to collapse and form polytomies if the maximum branch length was

1365 zero. This is the default setting for PAUP* and preferable to collapsing minimum branch lengths

1366 of zero for this small dataset as the latter method can be too strict for small datasets, eliminating

1367 possible topologies (Swofford \& Begle, 1993; Coddington \& Scharff, 1994). Nonetheless, a test

1368 run with the 'minbrlens' setting was conducted, but obtained the same results as 'maxbrlens', as

1369 there is good support for all recovered branches. The matrix was analyzed using the Branch and

1370 Bound ('bandb') search option and the resultant trees were rooted with the outgroup Postosuchus

1371 kirkpatricki ('outroot=para').

1372 A Permutation Tail Probability (PTP) test (Faith, 1991; Faith \& Cranston, 1991) was

1373 conducted to test whether the data contain a signal that differs significantly from random data.

1374 The result of $\mathrm{P}=0.01$ is demonstrative that the constructed dataset for this study ( 28 taxa, 83

1375 characters) is significantly more structured than a random dataset (Faith \& Cranston, 1991; Hillis

1376 \& Huelsenbeck, 1992).

\section{Results}

The initial run of 27 in-group taxa and 83 characters ( 80 parsimony informative), with the

1380 settings given above, yielded 30 most parsimonious trees (MPTs) with a length of 203 steps; a

1381 reported Consistency Index (C.I.) of 0.5567, Homoplasy Index (H.I.) of 0.4433, a Retention

1382 Index (R.I.) of 0.7345, and a Rescaled Consistency Index (R.C.) of 0.4089. The strict consensus 
1383 of these trees is provided in Figure $6 \mathrm{a}$ and features a large polytomy at the base of the tree. An

1384 Adams consensus (Adams, 1972) of the 30 MPTs (Figure 6b) recovers Aetobarbakinoides

1385 brasiliensis at the base of this large polytomy, and examination of the 30 MPTs demonstrates

1386 that this taxon occurs in 10 possible positions throughout the strict consensus tree including as

1387 the sister taxon to Revueltosaurus callenderi, the sister taxon to all aetosaurs, the sister taxon to

1388 the Desmatosuchinae, and the sister taxon to the Typothoracinae. A 50\% Majority Rule

1389 consensus tree (Figure 6c) places Aetobarbakinoides in a polytomy with Stagonolepis olenkae

1390 and Desmatosuchinae in $70 \%$ of the recovered trees. Coahomasuchus kahleorum is recovered in

1391 three positions in the strict consensus, as the sister taxon to Aetosaurus ferratus, the sister taxon

1392 to Typothoracinae, and as the sister taxon to Aetosaurus ferratus + Typothoracinae.

$1393 \quad$ A reduced consensus tree (Figure 6d) was generated by pruning Aetobarbakinoides

1394 brasilensis. Thus, this final matrix has 27 taxa and 83 characters ( 80 are parsimony informative).

1395 The reduced consensus tree has a length of 201 steps, a C.I. of 0.5622 , H.I. of 0.4378 , a R.I. of

13960.7373 , and a R.C. of 0.4145.

1397 The reduced consensus (Figures 6d, 7) features a nearly resolved topology with the

1398 exception of a clade with the unresolved polytomy that includes Coahomasuchus kahleorum,

1399 Aetosaurus ferratus, and Typothoracinae. Bremer support values were calculated for each node

1400 utilizing PAUP* by running repeated heuristic searches keeping trees one step longer in each

1401 iteration and noting which nodes collapse in strict consensus trees until no nodes remain. No

1402 nodes have a support value higher than four and many clades collapse after a single additional

1403 step (Figure 7).

1404 Bootstrap values were calculated using 600 replicates. Because of computational

1405 constraints I was unable to calculate bootstrap values using a higher number of replicates. 
1406 Although using more replicates provides a better representation of confidence values, replicate

1407 numbers as low as 100, will provide a "rough but useful estimate" (Efron, Halloran \& Holmes,

1408 1996: 13432). Bootstrap values for this analysis are provided for all nodes in Figure 7. Bootstrap

1409 values higher than 70\%, the minimum meaningful value according to Hillis \& Bull (1993), are

1410 noted in black, values less than $70 \%$ are provided in red, with values lower than $50 \%$ interpreted

1411 as having very low confidence. Synapomorphy lists for all nodes and definitions of clade names

1412 are provided in Appendix C.

1413 Aetosauroides scagliai was recovered at the base of the tree as a non-stagonolepidid

1414 aetosaurian, similar to the most recent analyses (Desojo, Ezcurra \& Kischlat, 2012; Heckert et

1415 al., 2015; Roberto-da-Silva et al., 2014). Stagonolepididae (Heckert and Lucas, 2000) comprises

1416 two major clades, Aetosaurinae (Heckert and Lucas, 2000) and Desmatosuchia (clade nov.;

1417 Appendix C). The former includes Paratypothoracini (Parker, 2007) as the sister taxon to a clade

1418 consisting of Typothorax coccinarum and Redondasuchus rineharti. Paratypothoracini includes

1419 Rioarribasuchus (=Heliocanthus) chamanensis, SMNS 19003 (Paratypothorax sp. of Sulej,

14202010 and Desojo \& Schoch, 2014), Tecovasuchus chatterjeei, Paratypothorax andressorum, and

1421 Paratypothorax sp. (North American Paratypothorax specimens). This clade is well supported

1422 by six unambiguous synapomorphies (listed below), as well as a high decay index ( +4$)$ and

1423 bootstrap value (95\%).

1424 The sister taxon to that clade $(($ Typothorax + Redondasuchus $)+$ Paratypothoracini $))$ is the

1425 recently described Apachesuchus heckerti Spielmann \& Lucas 2012, which is known from only a

1426 handful of osteoderms, and is situated here based mainly on the presence of the synapomorphy

1427 that supports the clade, width/length ratio of widest paramedian osteoderms 3.5 or higher

1428 (character 64-2). 
1429 In this analysis Typothoracinae, as defined by Parker (2007), would be equivalent to

1430 Aetosaurinae, so Typothoracinae is redefined here with an additional specifier (Aetosaurus

1431 ferratus, see Appendix C). Under this new definition Typothoracinae presently consists of

1432 Apachesuchus heckerti, Paratypothoracini, and Typothorax coccinarum + Redondasuchus

1433 rineharti. This clade is well supported by bootstrap values and decay indices (Figure 7).

1434 As previously mentioned Aetosaurus ferratus and Coahomasuchus kahleorum form a

1435 polytomy with Typothoracinae (Figure 7). This close relationship is novel, but not entirely

1436 unprecedented as these taxa were recovered as adjacent terminal taxa by Heckert et al. (2015)

1437 and Roberto-da-Silva et al., (2014). Nonetheless, because of the polytomy support for this clade

1438 is not robust and these taxa may form other relationships in future analyses. Stenomyti huangae

1439 (Small \& Martz, 2013) is recovered at the base of Aetosaurinae, but this position is also very

1440 weakly supported and at present there can be little confidence in this position.

1441 Desmatosuchia consists of two clades, Stagonolepidinae (Heckert \& Lucas, 2000) and

1442 Desmatosuchinae (Heckert \& Lucas, 2000). Stagonolepidinae consists of Stagonolepis

1443 robertsoni (by definition) and the newly described Polesinesuchus aurelioi (Roberto-da-Silva et

1444 al., 2014), however, this relationship is not very well supported with a decay index of +1 and a

1445 bootstrap value of $27 \%$ (Figure 7 ).

$1446 \quad$ At the base of Desmatosuchinae lie Stagonolepis olenkae Sulej 2010 and

1447 Neoaetosauroides engaeus (Figure 7). Neoaetosauroides was previously recovered outside of

1448 Desmatosuchinae by Parker (2007) and Desojo, Ezcurra \& Kischlat (2012), but within by

1449 Heckert \& Lucas (1999, 2000). Regardless these positions are not well supported with both

1450 branches having decay indices of +1 and bootstrap values under $10 \%$. 
1451 Nested deeper in Desmatosuchinae is a clade consisting of Calyptosuchus wellesi, which

1452 is the sister taxon to Adamanasuchus eisenhardtae + Scutarx deltatylus (Figure 7). These clades

1453 are fairly well supported with decay indices of +1 and bootstrap values in the high $60^{\text {th }}$ percentile

1454 nearly reaching the confidence threshold of 70\% proposed by Hillis \& Bull (1993). This is a

1455 novel position for these taxa as Adamanasuchus eisenhardtae and Calyptosuchus wellesi had

1456 been recovered outside of Desmatosuchinae in previous studies (e.g., Parker, 2007; Desojo,

1457 Ezcurra \& Kischlat, 2012). The presence of these five taxa within Desmatosuchinae is poorly

1458 supported with nodes having decay indices of only +1 and bootstrap values of less than $50 \%$

1459 (Figure 7). Thus, this part of the tree may also prove to be highly labile in future analyses.

1460 The subsequent nested clade within Desmatosuchinae; however, is highly supported by

146113 unambiguous synapomorphies, a decay index of +5 , and a bootstrap value of $94 \%$. I name this

1462 clade Desmatosuchini and define it in Appendix C. In this study Desmatosuchini is well-resolved

1463 and includes Gorgetosuchus pekinensis, Longosuchus meadei, Sierritasuchus macalpini,

1464 Lucasuchus hunti, and Desmatosuchus. This new clade has the same constituent taxa as

1465 Desmatosuchinae sensu Parker (2007).

1466

1467 DISCUSSION

1468 Comparisons to previous analyses

1469 Constituency and Status of Major Clades of Aetosauria

1470 Four major clades have been defined within Aetosauria: Stagonolepididae, Aetosaurinae,

1471 Stagonolepininae (emended to Stagonolepidinae by Sereno, 2005), and Desmatosuchinae

1472 (Heckert \& Lucas, 1999, 2000). A fifth, Typothoracinae, was added by Parker (2007). 
1473 Historically the terms Stagonolepididae and Aetosauria have been used interchangeably

1474 for family-group names under the Linnaean taxonomic system (see discussion in Walker, 1961),

1475 but were first defined cladistically by Heckert \& Lucas (2000), the former as stem-based and the

1476 latter as node based, although in that analysis they contained the same taxa. Parker (2007) also

1477 recovered these clades at a shared node, but cautioned that the definition provided by Heckert \&

1478 Lucas (2000) was based on Aetosaurus occupying the base of the tree and left open the

1479 possibility for non-stagonolepidid aetosaurs, which would alter the historic usage of the name.

1480 Rescoring of character states in Aetosauroides moved it to the base of Aetosauria as a non-

1481 stagonolepidid aetosaur (Desojo, Ezcurra \& Kischlat, 2012), a position recovered in all

1482 subsequent analyses including the present study (Roberto-da-Silva, et al, 2014; Heckert et al., 1483 2015).

1484 In the original defining analysis of Heckert \& Lucas, (1999), Aetosaurinae included

1485 only Aetosaurus; however, Parker (2007) and Parker, Stocker \& Irmis (2008) recovered

1486 Aetosaurinae as a greatly expanded clade that included all non-Desmatosuchines; however, this

1487 clade was generally unsupported and its constituents not accepted by all workers (e.g., Schoch,

1488 2007). Moreover, subsequent analyses (Desojo, Ezcurra \& Kischlat, 2012; Heckert et al., 2015)

1489 do not recover Aetosaurinae as a more inclusive clade with Aetosaurus ferratus the only

1490 constituent by original definition. In these analyses the remnant of the "Aetosaurines" (sensu

1491 Parker, 2007) are poorly resolved along the spine of Stagonolepididae.

1492 The present study recovers a different result (Figure 7) with Aetosaurus ferratus,

1493 Coahomasuchus kahleorum, and Stenomyti huangae, which was originally referred to the genus

1494 Aetosaurus (Small \& Martz, 2013), situated near the base of Aetosaurinae, which also includes

1495 the Typothoracinae. This still differs from Aetosaurinae as recovered by Parker (2007), which

1496 also included Stagonolepis robertsoni, Aetosauroides scagliai, Neoaetosauroides engaeus, and

1497 Calyptosuchus wellesi, all of which are now recovered as more closely related to Desmatosuchus

1498 (Figure 7). However, constraining the analysis to recover all of these taxa in a monophyletic

1499 Aetosaurinae (sensu Parker, 2007) now requires 11 additional steps. 
$1500 \quad$ As defined by Heckert \& Lucas (2000) Stagonolepidinae consisted of Stagonolepis

1501 robertsoni and Coahomasuchus kahleorum. Parker (2007) recovered Stagonolepidinae at the

1502 same node as Aetosaurinae and chose to use the latter name for that clade. Subsequently the

1503 name Stagonolepidinae has fallen out of use in recent analyses although it would have pertained

1504 solely to Stagonolepis robertsoni in other recovered topologies (Desojo, Ezcurra \& Kischlat,

1505 2012; Heckert et al., 2015). However, in the present study Stagonolepidinae is distinct from

1506 Aetosaurinae as originally conceived and consists of Stagonolepis robertsoni and Polesinesuchus 1507 aurelioi (Figure 7).

1508 Desmatosuchinae was first recovered as a clade by Heckert \& Lucas $(1999,2000)$ where

1509 it was comprised of Desmatosuchus, Typothorax, Paratypothorax, and Longosuchus; however,

1510 aspects of the published tree were affected by typographical and scoring errors, as well as

1511 reductive coding methods by Harris, Gower \& Wilkinson (2003), who provided a revised version

1512 of the Heckert \& Lucas (1999) matrix. The cladogram in Harris, Gower \& Wilkinson (2003)

1513 based solely on the revised Heckert \& Lucas (1999) matrix recovered Desmatosuchinae as

1514 consisting of Desmatosuchus, Longosuchus, Lucasuchus, and Acaenasuchus, all of which have

1515 remained constituent taxa in all subsequent analyses (Parker, 2007; Parker, Stocker \& Irmis,

1516 2008; Desojo, Ezcurra \& Kischlat, 2012, Heckert et al., 2015; this study), although this present

1517 study did not include Acaenasuchus as an Operational Taxonomic Unit (see explanation above).

1518 The present study differs from all others in recovering several taxa within

1519 Desmatosuchinae for the first time, including Stagonolepis olenkae, Neoaetosauroides engaeus,

1520 Adamanasuchus eisenhardtae, Scutarx deltatylus, and Calyptosuchus wellesi (Figure 7).

1521 Nevertheless, support for these included taxa is weak, and it is probable that in future analyses

1522 they may continue to migrate between the bases of Aetosaurinae and Desmatosuchia. A new

1523 robust clade, Desmatosuchini, is erected for the taxa originally within Desmatosuchinae (sensu

1524 stricto) as originally recovered by Harris, Gower \& Wilkinson (2003) and Parker (2007).

1525 Typothoracinae was first recovered and defined by Parker (2007) and is comprised of

1526 taxa more closely related to Typothorax and Paratypothorax than to Aetosaurus, Stagonolepis, or 
1527 Desmatosuchus. This clade was well-supported by Parker (2007) and has been recovered in all 1528 subsequent analyses including the present analysis (Figure 7).

1529 Desmatosuchinae and Aetosaurinae were recovered as sister taxa, with Typothoracinae

1530 nested within Aetosaurinae (Parker, 2007). Desojo, Ezcurra \& Kischlat (2012) and Heckert et al.

1531 (2015) did not recover a similar topology after rescoring and adding taxa to the Parker (2007)

1532 matrix. Instead they presented trees with Desmatosuchinae and Typothoracinae as sister taxa.

1533 The present analysis recovers Typothoracinae within Aetosaurinae and a distinct

1534 Desmatosuchinae (Figure 7).

1535 In sum, the results of five most recent phylogenetic analyses demonstrate that

1536 Typothoracinae and Desmatosuchini are robust clades within Aetosauria, well-supported and

1537 stable when taxa are added and scorings are changed. Recovery of an inclusive Aetosaurinae is

1538 not consistent across studies, with weak support values for non-desmatosuchine and

1539 typothoracine taxa causing the constituent taxa to be shuffled around the base of the tree in most 1540 studies. The significance of and a possible reason for this are addressed below.

\section{The Monophyly of Stagonolepis}

1543 It has been recognized that aetosaurian material, especially osteoderms, recovered from

1544 southwestern North America (Chinle Formation, Dockum Group) is very similar in overall

1545 anatomy to that of Stagonolepis robertsoni. In fact, the first person to directly compare these

1546 materials was convinced of their congeneric status (Charles Lewis Camp, unpublished notes,

1547 1935). The North American material was eventually named Calyptosuchus wellesi by Long \&

1548 Ballew (1985); however, soon afterwards that species was reassigned to the genus Stagonolepis

1549 (Murry \& Long, 1989; Long \& Murry, 1995).

1550 This potential relationship was first discussed in a numerical phylogenetic framework by

1551 Heckert \& Lucas (1999:62) who noted that Calyptosuchus wellesi and Stagonolepis robertsoni

1552 "score almost identically throughout the matrix", and therefore they removed Calyptosuchus 
1553 wellesi prior to their final run. For the same reasons they removed Aetosauroides scagliai, 1554 considering it also to represent Stagonolepis robertsoni and several anatomical descriptions were 1555 published detailing these proposed synonymies (Lucas \& Heckert, 2001; Heckert \& Lucas, 1556 2002). However, investigation of the original matrix by Harris et al., (2003) determined that

1557 because these three taxa were not scored identically, Calyptosuchus wellesi and Aetosauroides

1558 scagliai could not be removed without affecting the final analysis. A reanalysis did not recover a 1559 "Stagonolepis" clade with Calyptosuchus wellesi and Stagonolepis robertsoni, but did find a 1560 clade with Stagonolepis robertsoni and Aetosauroides scagliai (Harris, Gower \& Wilkinson, 1561 2003: fig. 9).

1562 The strict consensus tree published by Parker (2007: fig. 13) offered no resolution to this

1563 problem, recovering all three taxa in an unresolved polytomy with Aetosaurus ferratus.

1564 However, Desojo (2005) argued against the synonymy of Aetosauroides and Stagonolepis and in 1565 a recent redescription of Aetosauroides scagliai demonstrated key differences in the skull and 1566 postcranial skeleton that preclude an assignment of that material to Stagonolepis robertsoni 1567 (Desojo \& Ezcurra, 2011). More recent phylogenetic analyses featuring a rescoring of 1568 Aetosauroides scagliai do not recover the three 'Stagonolepis-like' species as a discrete clade 1569 (Desojo, Ezcurra \& Kischlat, 2012; Heckert et al., 2015). The present study rescores

1570 Calyptosuchus wellesi based on material from the Placerias Quarry (Parker, 2014) and also does 1571 not recover Stagonolepis, Calyptosuchus, and Aetosauroides as a discrete clade. Constraining the 1572 present analysis to recover them in an exclusive clade requires 10 additional steps. Thus, 1573 anatomical comparisons and several phylogenetic analyses strongly support the separation of 1574 these three taxa and the genera Calyptosuchus and Aetosauroides should no longer be considered 1575 junior synonyms of Stagonolepis (Parker, 2008a; Desojo \& Ezcurra, 2011).

1576 Numerous well-preserved cranial bones from Krasiejów Poland were described as a new 1577 species of Stagonolepis, Stagonolepis olenkae (Sulej, 2010). Postcranial bones and osteoderms 1578 were also recovered from the same quarry (Dzik, 2001; Dzik \& Sulez, 2007) and were assigned 1579 to Stagonolepis robertsoni by Lucas, Spielmann \& Hunt (2007). In a traditional (i.e., non- 
1580 cladistic) analysis Stagonolepis olenkae was considered to be an early member of an anagenetic

1581 'Stagonolepis-Aetosaurus' lineage (Sulej, 2010). Differences between Stagonolepis olenkae and

1582 Stagonolepis robertsoni appear to all be in the skull and include contrasting dimensions of

1583 various cranial bones, the presence of a massive ridge on the anterior end of the palatine in

1584 Stagonolepis olenkae, the presence of a lateral ridge on the maxilla of Stagonolepis robertsoni,

1585 and most notably a reduced number of dentary teeth and the presence of large tubercles on the

1586 parietals of Stagonolepis olenkae (Sulej, 2010). These were considered to possibly represent

1587 individual variation by Antczak (2015), who suggested that the Krasiejów material is probably

1588 referable to Stagonolepis robertsoni. In the phylogenetic analysis presented here these two taxa

1589 are scored differently for five characters, four are cranial and the fifth is that the humeral head is

1590 more expanded in Stagonolepis olenkae. In the recovered tree Stagonolepis robertsoni+

1591 Polesinesuchus aurelioi is the sister taxon to Stagonolepis olenkae + Desmatosuchinae. A

1592 topological constraint to force the two purported species of Stagonolepis to form an exclusive

1593 clade requires only an additional two steps. Therefore, even though both purported species were

1594 not recovered as a clade, I do not suggest erecting a new generic name to receive Stagonolepis

1595 olenkae. Differences between the taxa are too few and potentially explained by the much larger

1596 size of Stagonolepis olenkae, although Sulej (2010) explicitly argued against this possibility. A

1597 full description of the postcranial material and osteoderms will hopefully provide further

1598 evidence for or against the potential generic synonymy of these two taxa although a preliminary

1599 analysis proposes synonymy (Antczak, 2015).

1600

\section{The Phylogenetic Position of Aetosaurus ferratus}

1602 The earliest exhaustive treatment of the Aetosauria (Walker, 1961) considered

1603 Aetosaurus ferratus as the 'basal' aetosaurian, a position supported by the first phylogenetic

1604 analyses of the Aetosauria (Parrish, 1994; Heckert, Hunt \& Lucas, 1996; Heckert \& Lucas,

1605 1999). Indeed, an early study constrained Aetosaurus ferratus to this position by utilizing it as 
1606 the sole outgroup for the entire analysis (Heckert, Hunt \& Lucas, 1996). Nonetheless that study

1607 considered other aetosaurs to be more 'advanced' than Aetosaurus based on characters of the

1608 teeth, especially the presence of bulbous rather than recurved teeth and an edentulous anterior

1609 portion of the dentary. Those characters and scorings for Aetosaurus were taken directly from

1610 Parrish (1994), and used again by Heckert \& Lucas (1999) to diagnose Aetosaurus. Parker

1611 (2007) followed Walker (1961:164) in considering the teeth of Aetosaurus bulbous, rather than

1612 mediolaterally flattened and recurved, with the anterior portion of the dentary edentulous. In the

1613 accompanying analysis Aetosaurus ferratus was recovered more deeply nested within

1614 Stagonolepididae (Parker, 2007), the first time it had not been recovered at the base of

1615 Aetosauria in a phylogenetic analysis (Parrish, 1994; Heckert, Hunt \& Lucas, 1996; Heckert \&

1616 Lucas, 1999). This alternate placement prompted detailed discussion by Schoch (2007) who

1617 acknowledged that the teeth were as Walker (1961) had described, but argued that the more

1618 nested placement of Aetosaurus was somewhat ambiguous as other character states found in

1619 Aetosaurus ferratus supported a position closer to the base of Aetosauria.

1620 In subsequent analyses (Desojo, Ezcurra \& Kischlat, 2012; Heckert et al., 2015)

1621 Aetosaurus has been recovered closer to the base of Aetosauria in part mainly because of a

1622 change in character polarities based on the scoring of Aetosauroides scagliai as having a maxilla

1623 that is excluded from the margin of the external naris (Desojo \& Ezcurra, 2011); a change that

1624 pulled both Aetosauroides and Aetosaurus towards the root of the tree. In the present analysis

1625 Aetosaurus is recovered in a polytomy with Coahomasuchus and Typothoracisinae, and two taxa

1626 are still fairly close to the base of Aetosauria (Figure 6), but constraining the clade of Aetosaurus

1627 plus Coahomasuchus to the base of Aetosauria requires an additional six steps.

1628

1629 Low Support Values in Data Partitions

1630 Overall, the tree of Heckert et al. (2015) is the most similar of all past studies to the novel 1631 one presented here, suggesting that the incorrect scorings that affected the earliest analyses 
1632 (Parrish, 1994; Heckert, Hunt \& Lucas, 1996; Heckert \& Lucas, 1999) still played a major role in

1633 the recovered topology of Parker (2007). Some of these errors were directly inherited from the

1634 previous studies (Parrish, 1994; Heckert, Hunt \& Lucas, 1996), but others resulted from a

1635 general lack of good specimens and a necessary reliance on outdated literature to score

1636 characters as redescriptions of key taxa such as Aetosaurus ferratus, Aetosauroides scagliai,

1637 Neoaetosauroides engaeus, and Desmatosuchus spurensis had not yet been published (Desojo \&

1638 Báez, 2005, 2007; Schoch, 2007; Parker, 2008b; Desojo \& Ezcurra, 2011). Still, this early work

1639 should be recognized for pioneering phylogenetic studies of aetosaurians, especially the study of

1640 Heckert, Hunt \& Lucas (1996), which introduced many key characters still used in current

1641 analyses. However, this also demonstrates the importance of discovering and utilizing new

1642 specimens of existing taxa (e.g., MNA V9300, PEFO 38001/YPM 58121; NMMNH P-56299;

1643 TMM 31100-437), as well as crucial reinvestigations of original type materials (e.g., Desojo \&

1644 Báez, 2005, 2007; Schoch, 2007), in phylogenetic work.

1645 I find the results of the new study presented here to be generally disappointing because of

1646 the lack of support for the base of the tree, essentially all nodes outside of Typothoracinae and

1647 Desmatosuchini. This problem also plagued the previous study by Parker (2007) and was

1648 apparent in the way topologies shifted significantly in new studies when characters were

1649 rescored and new taxa added (Desojo, Ezcurra \& Kischlat, 2012; Heckert et al., 2015). The

1650 present work sought to increase character support by creating as many new characters as

1651 possible, particularly those from skeletal elements outside of the dorsal carapace. Inclusion of

1652 endoskeletal (non-armor) characters was suggested as a way to provide tree stability (Desojo,

1653 Ezcurra \& Kischlat, 2012; Heckert et al., 2015).

1654 Parker (2007) scored 35 parsimony informative characters with $23(66 \%)$ of these

1655 characters from the osteoderms. This new study has expanded the dataset to 80 parsimony

1656 informative characters, an increase of over $100 \%$, with only 31 of these characters scoring

1657 osteoderm characters (39\%). Thus, it was expected to see an increase in stability in the overall 
1658 tree metrics utilizing a dataset with better skeletal region sampling, but unfortunately this was 1659 not realized in the final results.

1660 One of the possible reasons for these low support values is that the non-osteoderm

1661 characters of aetosaurians appear to generally have higher levels of homoplasy. For example, the

166235 parsimony informative cranial characters have an average C.I. value of 0.596. This value was

1663 computed by simply adding up the C.I. scores for each character and dividing the resulting

1664 number by the number of characters, thus this is a calculation of a 'raw' C.I. average and does

1665 not equate the final reported C.I. number for the MPTs as determined by PAUP*. Vertebral

1666 characters score much higher with an average C.I. value of 0.767 . However, the paramedian

1667 osteoderm characters have an average value of 0.697 , whereas the lateral osteoderms have an

1668 average value of 0.833 demonstrating the value of the osteoderm characters. Overall the non-

1669 osteoderm characters have an average C.I. value of 0.606 , compared to an average value of 0.746

1670 for the osteoderm characters. What this signifies is that the non-osteoderm characters included in

1671 the study are more apt to change across the tree than the osteoderm characters, which signifies a

1672 higher degree of homoplasy in non-osteoderm characters or that non-comparable maturity at time

1673 of death among specimens plays a greater role than expected.

1674 Overall, sampling of non-osteoderm characters remains poor, with the majority of

1675 characters taken from the cranial region. Only four characters sample the appendicular skeleton,

1676 and the limbs and girdles represent a potential area for character expansion. Unfortunately, many

1677 aetosaur taxa do not have limb and girdle material referred to them, and, in some cases, these

1678 materials are present but covered by an articulated carapace and not accessible for study without

1679 non-invasive (e.g., CT) scanning. Where limb and girdle elements are known (e.g., femora,

1680 scapulae, ilia) many of the characters appear to be conserved across taxa. Still, with increasing

1681 sample sizes and better comparisons, more informative characters can probably be derived from

1682 this dataset in future analyses.

1683 


\section{Dataset Partitioning}

1685 An interesting question brought up during the construction of this dataset is what if

1686 aetosaurians did not possess an extensive armor carapace? What if all of the characters and

1687 character states used in phylogenetic analyses of the Aetosauria were derived from the skull,

1688 axial, and appendicular portions of the skeleton as is the case for the majority of vertebrate

1689 animals? In sum, what would the phylogeny of aetosaurians look like without utilizing characters

1690 of the osteoderms?

1691 One particular aspect of phylogenetic data set analysis is the discussion of data

1692 partitioning, which entails the separation of a data set of phylogenetic characters into discrete

1693 parts based on types of characters (e.g., molecular sequences vs. morphological; Kluge, 1989), or

1694 modular (e.g., skull vs. postcranium; Mounce, 2013). In most published cases, the debate over

1695 data partitioning in phylogenetic analyses revolves around the advantages or disadvantages of

1696 combining molecular sequence and morphological data into a single data set (e.g., Bull et al.,

1697 1993). Considerable discussion is available regarding partitioning of strictly morphological data

1698 into discrete character sets based mainly on anatomical subregions (Rowe 1988; Gauthier, Kluge

1699 \& Rowe 1988; Donoghue et al. 1989; Rae, 1999; Clarke \& Middleton, 2008; Mounce, 2013), but

1700 none pertains to the special case of osteoderms versus endoskeletal features.

1701 Aetosaurians provide an excellent example of a group where historically the taxonomy is

1702 based almost entirely on characters from a single non-cranial anatomical subregion. A major

1703 assumption of aetosaur workers is that not only is osteoderm anatomy taxonomically

1704 informative, but that it is also phylogenetically significant, providing an accurate signal of

1705 evolutionary relationships within the group (Parker, 2007). Dataset partitioning provides a test of

1706 which characters, in this case integumentary versus non-integumentary, are providing the main

1707 phylogenetic signal for this group and allows for in-depth examination of possible underlying

1708 factors regarding the poorly resolved phylogenetic relationships recovered in past studies (Harris,

1709 Gower \& Wilkinson, 2003).

1710 


\section{Why partition?}

1712 Osteoderms represent a mineralized component of the dermis in tetrapods (Romer, 1956;

1713 Hill, 2005). As such they are hypothetically an autonomous (i.e., they are not found in all

1714 vertebrates) unit (module) of the skeletal and circulatory systems. This independence is further

1715 supported by the finding that onset of osteoderm development is delayed, by as much as a year,

1716 in comparison with the rest of the skeleton in Alligator with the result that they are absent in very

1717 young animals (Vickaryous \& Hall, 2008). This independence also suggests that the osteoderms,

1718 with specific proposed functions (e.g., defense, heat transfer, species recognition; Seidel, 1979;

1719 Main et al., 2005), may be under different evolutionary selection pressures than other parts of the

1720 body such as the head, which is mainly focused on resource acquisition, or the limbs, which are

1721 mainly focused on locomotion and/or environmental manipulation. Thus, they can be considered

1722 a distinct module of the skeleton. This begs the question of how does the non-integumentary

1723 portion of the aetosaur skeleton compare to other taxonomic groups, but more importantly how

1724 does it compare within Aetosauria proper?

\section{Methods}

1726 Morphobank (O’Leary \& Kaufmann, 2012) was used to divide the main dataset into 1727 smaller partitions based on cranial characters, osteoderm characters, and the full set of non1728 osteoderm characters. The cranial dataset consists of characters 1-35, the osteoderm dataset 1729 consists of characters 52-83, and the full endoskeletal set consists of characters 1-51. All 1730 analyses for this study were run using PAUP* version 4.0.b10 (Swofford, 2003). All characters

1731 were weighted equally and the most parsimonious trees (MPTs) were subject to an exact solution 1732 search using the branch and bound implementation under the program default settings. Bootstrap 1733 support values for each dataset were calculated from 1000 replicates with only scores above 50\% 1734 being recorded as informative, although only values above $70 \%$ probably represent well- 
1735 supported clades (Hillis \& Bull, 1993). Distribution of character states was analyzed in Mesquite

17362.75 (Maddison \& Maddison, 2011).

1737 The reduced consensus tree provided earlier utilized the full data set for this entire project

1738 (26 in-group taxa and 83 characters) and establishes the baseline relationships for this study. For

1739 this portion of the study runs used the subsets outlined above. Because several taxa are only

1740 known from osteoderms (e.g., Apachesuchus heckerti, Redondasuchus rineharti,

1741 Rioarribasuchus chamaensis) it was necessary to remove taxa where no characters could be

1742 scored for one of the partitions, as inclusion of taxa with no scored characters causes the

1743 algorithm to generate all possible trees, which increases exponentially given the total number of

1744 taxa with the end result of a completely unresolved consensus tree. Therefore all taxa lacking

1745 skull material were also removed from the matrices so that the final trees could be directly

1746 compared. Taxa were also removed if taxonomic equivalence could be demonstrated, utilizing

1747 the Safe Taxonomic Reduction method of Wilkinson (1995a) to reduce the number of MPTs and

1748 increase resolution. For the cranial set this included Tecovasuchus chatterjeei, which can only be

1749 scored for two characters, and for Desmatosuchus spurensis, which for this partition is

1750 identically coded to Desmatosuchus smalli. Desmatosuchus smalli was retained for the analysis

1751 as its overall scoring contains fewer missing data (98\% complete). For the osteoderm-only

1752 dataset this included Stagonolepis olenkae, which is scored identical to Stagonolepis robertsoni,

1753 Desmatosuchus spurensis which is scored the same as Desmatosuchus smalli, and

1754 Redondasuchus rineharti, which is scored the same as Typothorax coccinarum. The final

1755 partition datasets initially contain 13 taxa. Postosuchus kirkpatricki and Revueltosaurus

1756 callenderi are utilized as the outgroup, and the in-group taxa consist of Aetosaurus ferratus,

1757 Stagonolepis robertsoni, Scutarx deltatylus, Aetosauroides scagliai, Coahomasuchus kahleorum,

1758 Desmatosuchus smalli, Longosuchus meadei, Neoaetosauroides engaeus, Typothorax

1759 coccinarum, SMNS 19003, and Stenomyti huangae.

1760 A 'Simultaneous Analysis' dataset (all 83 characters; sensu Baker \& DeSalle, 1997),

1761 although with the reduced number of taxa (13), was run to see the effects of reduced taxon 
1762 sampling, which has been hypothesized to reduce phylogenetic accuracy (Hillis, 1998), and to

1763 establish a baseline topology for comparison with the partitioned datasets. Nonetheless, it should

1764 be recognized that partitioning datasets is an analytical tool and should not be expected to

1765 represent the final phylogenetic hypothesis. This simultaneous analysis matrix was subsequently

1766 portioned into three datasets, one including only cranial characters, another including only

1767 osteoderm characters, and a third including all non-osteoderm characters including the cranial

1768 set. All uninformative and constant characters were excluded, further reducing the sizes of the

1769 matrices to less than half of the taxa originally scored (13 taxa, 35 characters from the cranial set;

177013 taxa, 24 characters for the osteoderm only set, and 13 taxa, 46 characters for the non-

1771 osteoderm only set). Because the datasets were reduced, Permutation Tail Probability (PTP)

1772 tests were run in PAUP* to test the null hypothesis that the datasets are no better than random

1773 and thus phylogenetically uninformative (Faith \& Cranston, 1991). The cranial and the armor

1774 only datasets had PTP scores of 0.01 and the endoskeletal dataset had a score of 0.02 which are

1775 less than the required PTP of 0.05 that is considered to be significant, thus falsifying the null

1776 hypothesis. These datasets were run under the branch and bound settings in PAUP* and the

1777 results of the partition sets were compared with each other, as well as to the full and reduced

1778 taxon datasets containing all 83 characters.

1779

1780 Results

1781 Reduction of the number of taxa in the full working matrix from 28 to 13 taxa produced

178214 parsimony-uninformative characters (including four constant characters) out of the original

1783 set of 83. The uninformative characters were excluded a priori from the final matrix of 69

1784 characters and 12 in-group taxa. Ten characters were unordered. The initial run (branch and

1785 bound) resulted in three most parsimonious trees of 178 steps. The strict consensus of which

1786 (C.I. $=0.6067$, H.I. $=0.3933$, R.I. $=0.5270$, R.C. $=0.3198$ ), which is provided in Figure 8a.

1787 This tree is similar to the reduced strict consensus tree recovered in the complete analysis 
1788 presented earlier except that the base of Aetosauria is unresolved, consisting of Stenomyti,

1789 Stagonolepis, Aetosaurinae and Desmatosuchinae. Nonetheless, taxa recovered in Aetosaurinae

1790 and Desmatosuchinae in the full analysis are recovered in those same clades in this reduced

1791 analysis. Thus the reduction of taxa as well as the loss of the 14 constant/uninformative does not

1792 significantly change relationships within the tree.

1793 Overall clade support in the base of the reduced matrix tree is not good, with some clades

1794 collapsing with only a single additional step. However, Typothoracinae (Typothorax + SMNS

1795 19003) collapses after six steps, and Desmatosuchini (Desmatosuchus + Longosuchus) is

1796 particularly well-supported, not collapsing until nine additional steps. Thus, there appears to be

1797 no negative effects to clade support as a result of reduced taxon sampling as the nodes are even

1798 better supported than in the tree recovered for the complete analysis. Thus, this reduced matrix

1799 tree provides a suitable baseline topology to compare to the other partition sets.

1800 A branch and bound search of the reduced matrix utilizing the osteoderm only dataset (12

1801 in-group taxa, 24 informative characters, eight ordered; outgroup constrained) results in a strict

1802 consensus tree (Figure 8b) from three MPTs of 58 steps each (C.I. $=0.8276$, R.I. $=0.7727$, R.C.

$1803=0.6395)$. These metrics are high, suggesting that there is reduced homoplasy in this data

1804 partition $($ H.I. $=0.1724)$. Nonetheless, the recovered tree topology is mostly unresolved and

1805 poorly supported. Four clades are recovered; 1) Desmatosuchus smalli + Longosuchus meadei,

1806 which is the sister taxon to all of the other aetosaurians; 2) all of the non-desmatosuchine taxa; 3)

1807 Stenomyti huangae + Neoaetosauroides engaeus, and 4) Typothorax coccinarum + SMNS 19003

1808 (Figure 7b). In this partitioned analysis Stenomyti + Neoaetosauroides is supported by two

1809 unambiguous synapomorphies, dorsal eminence of the dorsal paramedian osteoderms is strongly

1810 offset medially (66-2), and anterolateral projection of the anterior bar of the dorsal paramedian

1811 osteoderms is present and elongate (68-1). Typothorax coccinarum + SMNS 19003 are supported

1812 by six unambiguous synapomorphies: 1) lateral edge of the dorsal paramedian osteoderms in

1813 dorsal view are strongly sigmoidal with a strongly posteromedially oriented posterolateral corner

$1814(63-1) ; 2)$ width/length ratio of widest paramedian osteoderms (rows 9-11) in dorsal trunk series 
1815 is greater than $3.5(64-2) ; 3)$ dorsal eminence of cervical lateral osteoderms is a moderate length,

1816 dorsoventrally flattened, slightly recurved spine (74-1); 4) mid-dorsal lateral osteoderms with a

1817 strongly acute angle of flexion between the dorsal and lateral flanges (79-2); 5) lateral flange of

1818 pelvic and anterior caudal lateral osteoderms is roughly triangular in lateral vie with a

1819 semicircular ventrolateral border and a hook-like eminence (81-1); and 6) carapace is broad and 1820 discoidal in dorsal view (82-2).

1821 Desmatosuchus plus Longosuchus (Desmatosuchini) is the best supported clade with 14

1822 unambiguous synapomorphies: 1) cervical paramedian osteoderms are longer than wide (57-1);

1823 2) ratio of cervical vertebrae/paramedian osteoderms significantly less than $1: 1(58-1) ; 3)$

1824 adjacent paramedian and lateral cervical osteoderms are often fused (59-1); 4) in the paramedian

1825 osteoderms dorsal to the cervical and anterior trunk vertebrae, lateral edge articulation with

1826 lateral osteoderms is dorsoventrally thickened, angled contact, with deeply incised interdigitation

1827 (='tongue and groove') (60-1);5) dorsal eminence shape in the cervical paramedian osteoderms

1828 are a low pyramidal or rounded boss, or elongate keel (61-1); 6) in the dorsal trunk paramedian

1829 osteoderms the anterior edge of the lateral osteoderm overlaps the anterior edge of the

1830 paramedian osteoderm (62-1); 7) lacks the sharp anteromedial projection of the anterior bar

1831 (reversed in Lucasuchus hunti) (67-1); 8) the anterior bar of the trunk distal paramedian

1832 osteoderms lacks an anterolateral projection (68-2); 9) anterior bar of the dorsal trunk

1833 paramedian osteoderms lacks scalloping of the anterior margin on the medial side of the

1834 osteoderm $(69-1) ; 10)$ dorsal eminence in the mid-trunk osteoderms is a conical spike $(78-2) ; 11)$

1835 approximately 90 degree angle between the dorsal and lateral flanges of the mid-trunk lateral

1836 osteoderms (79-1); 12) dorsal trunk lateral osteoderms strongly asymmetrical with the dorsal

1837 flange longest (80-1); 13) lateral flange of the pelvic and anterior caudal lateral osteoderms are

1838 rectangular and ventral to a well-developed spine (81-2); and 14) overall shape in of the dorsal

1839 carapace in dorsal view is moderately spinose (82-1).

1840 Overall support is mixed with the clades Neoaetosauroides + Stenomyti, and Typothorax

$1841+$ SMNS 19003 having Decay Indices of +1 and +2 respectively, but Desmatosuchus plus 
1842 Longosuchus is very strongly supported with a Decay Index of +9 . Furthermore, Typothorax +

1843 SMNS 19003 has a bootstrap value of $86 \%$ for 1000 replicates, and Desmatosuchus plus

1844 Longosuchus occurs in 100\% of the replicates (Figure 8b).

1845 A branch and bound run of the endoskeletal (non-osteoderm) dataset (12 in-group taxa,

184646 informative characters, four ordered) results in two MPTs of 115 steps (C.I. $=0.5217$, H.I. $=$

18470.4783 , R.I. $=0.4762$, R.C. $=0.2484$ ), the strict consensus of which is shown as Figure 8c. The

1848 tree is nearly completely resolved and the topology more closely resembles the total evidence

1849 tree rather than the cranial only tree. Aetosauroides is recovered at the base of the tree, and the

1850 clade (Neoaetosauroides $+($ Scutarx $+($ Desmatosuchus + Longosuchus $)))$ is recovered. A

1851 significant difference, however, is that SMNS 19003 forms a novel clade with Aetosaurus in this

1852 partition tree rather than with Typothorax. Therefore the clade Typothoracinae is not supported

1853 by this character set. Support for this topology is weak with only clade (Aetosauria) with a

1854 bootstrap value higher than 50\%. Aetosaurus + SMNS 19003 has a Decay Index of +1 , a

1855 bootstrap value of $48 \%$, and is supported by three unambiguous synapomorphies: 1) ventrolateral

1856 margin of the nasal forms part of the dorsal border of the antorbital fossa $(10-1)$; 2$)$ postorbital

1857 contacts quadratojugal (15-1); and 3) ) supratemporal fenestra is greatly reduced in size

1858 compared to the orbit (22-2).

1859 A subset of the non-osteoderm dataset, consisting of only cranial characters, was also run

1860 using the branch and bound search criteria. This run (12 in-group taxa, 35 informative characters,

1861 four ordered) resulted in thirteen MPTs of 82 steps (C.I. $=0.5488$, H.I. $=0.4512$, R.I. $=0.5542$,

1862 R. C. $=0.3041$ ) shown as Figure 8d. This tree is most similar to the non-osteoderm dataset tree,

1863 but less resolved. The base of the tree is a large polytomy with Aetosaurus, Aetosauroides,

1864 Typothorax, Coahomasuchus, SMNS 19003, and Stenomyti. Longosuchus and Desmatosuchus

1865 form a clade (Desmatosuchini) with Scutarx, Neoaetosauroides, and Stagonolepis robertsoni as

1866 successive sister taxa. Support is no better than in the endoskeletal (non-osteoderm) tree, with all

1867 clades a Decay Indices of +1 and a bootstrap values less than 50\% (Figure 8d). As with the 
1868 endocranial set Typothoracinae is not recovered. However, neither is the clade Aetosaurus +

1869 SMNS 19003, which was recovered in the endocranial set.

1870

1871 Dataset Incongruence

1872 A partition homogeneity test was conducted in PAUP* for the 'simultaneous analysis'

1873 matrix (excluding uninformative characters following the recommendations of Lee, 2001)

1874 divided into three partitions (osteoderm, postcranial, and cranial) using the CHARSET command

1875 in PAUP*. The test resulted in a p-value score of 0.03 suggesting that some character conflict

1876 exists between the partitioned datasets. Incongruence Length Difference (ILD) tests (Farris et al.,

1877 1995) were run for each partition set, comparing each to the other two sets. The test without the

1878 cranial set had a p-value score of 0.70 , that without the endoskeletal (non-osteoderm) set had a

1879 score of 0.08 , and the test excluding the osteoderm set had a p-value of 0.35 . These results all

1880 show significant incongruence over the 0.05 threshold. These numbers also suggest that although

1881 the cranial and osteoderm sets are the most compatible, with low conflict, the osteoderm and

1882 postcranial sets and the cranial and postcranial sets have high levels of conflict. Size differences

1883 between the partitions (i.e. number of characters) do not influence the ILD test, thus datasets

1884 with higher amounts of characters do not 'overwhelm' partitions with lower numbers of

1885 characters (Farris et al., 1995; Baker, Yu \& DeSalle, 1998). Therefore these scores are the result

1886 of dataset incongruence.

1887 Bull et al., (1993) argued that dataset partitions with high levels of character conflict

1888 should not be combined for analyses (the prior agreement approach), whereas others (e.g., Kluge,

1889 1989; Barrett, Donoghue \& Sober, 1991) argue that data should be combined in all cases (the

1890 total evidence approach). Still others argued that these debates have been mostly theoretical and

1891 it is important to examine the actual data to understand the consequences of these approaches

1892 (Baker \& DeSalle, 1997). The Partition Homogeneity Test (and ILD) measures levels of

1893 disagreement between partitions, but does not identify specific nodes where this conflict occurs 
1894 (Lambkin et al., 2002). Baker \& DeSalle (1997) developed a new measure, Partitioned Bremer

1895 Support (PBS) to determine the amount of support individual data partitions contribute to the

1896 branch support of the full matrix. Partition datasets that conflict with other datasets at the same

1897 node will contribute negatively to the overall branch support. Therefore isolating Bremer

1898 Support values for nodes by partition allows for the determination of localized areas of

1899 disagreement. The higher the negative PBS number, the greater the support that partition

1900 provides for an alternative node that is not present in the combined data tree (Lambkin, 2004;

1901 Brower, 2006). Moreover, strong variance in PBS scores for nodes, demonstrates conflict

1902 between partitions for node resolution (Lambkin, 2004). Neutral (0) scores indicate that there is

1903 within-dataset incongruence and that the particular partition is ambivalent about the node,

1904 reducing overall support (Lambkin et al., 2002).

1905 The program TreeRot.v3 (Sorenson \& Franzosa, 2007) was employed to calculate PBS

1906 values for the partitioned dataset. This method works back and forth between the TreeRot.v3

1907 program and PAUP*. First the 'simultaneous analysis' matrix is run in PAUP* using the same

1908 parameters as the earlier run (12 in-group taxa, 69 informative characters, ten characters ordered,

1909 branch and bound search) with the three partitions set-up using the CHARSET command.

1910 PAUP* was also used to calculate Bremer Support (BS) values for the entire dataset. The

1911 resulting tree file is then entered into TreeRot to generate a PAUP* command file, which

1912 includes the Partitioned Bremer Support (PBS) values. Minimum, maximum and averaged

1913 values are given for each partition at each node. Baker \& DeSalle (1997) recommended utilizing

1914 the averaged value, but Lambkin et al., (2002) argued that averaging masks some of the conflict

1915 found at each node. For this study I did use the averaged values, however, because it is the

1916 averaged values for each partition that sum to match the Bremer Support value listed for each

1917 node. The values for this analysis are provided for branches in Figure 8a. There are three

1918 numbers listed, the first is from the cranial character set, the second from the postcranial

1919 (vertebrae, girdles, limbs) character set, and the third from the osteoderm character set. Note that

1920 the three PBS values equal the total BS value for that branch and as mentioned earlier negative 
1921 numbers denote negative support (homoplasy) and neutral numbers indicate node ambivalence

1922 for that dataset. Also note that these character set (CHARSET) divisions are for the purpose of

1923 determining the PBS and do not pertain directly to the partition dataset trees presented in Figures

1924 8b-d.

1925 The cranial character set supports eight nodes, showing no conflict with the other

1926 character sets, although support is low for four of these nodes (below +0.5$)$. The postcranial

1927 character set supports only a single node (Coahomasuchus + Typothoracinae), but is mostly

1928 neutral except for two nodes where it shows moderate conflict with the other datasets, especially

1929 in one node, Desmatosuchus + Longosuchus (=Desmatosuchini), which has a PBS of -1.50. The

1930 osteoderm character set shows positive, but low, for seven out of eight nodes, including good

1931 support (+5.53) for Desmatosuchinae. The osteoderm character set shows conflict for

1932 Desmatosuchini (-1.17). In sum, character dataset conflict occurs in two nodes, Aetosauria and

1933 Desmatosuchini, with all conflict occurring with the postcranial and osteoderm datasets (Figure

1934 8a) meaning that these partitions better support alternative phylogenies.

1935

1936 Discussion

1937 Dataset partitioning and partition homogeneity tests (PHT) strongly suggest that the main

1938 character suites (i.e. cranial, postcranial, osteoderm) possess some conflicting phylogenetic

1939 signals. The PHT suggests that the postcranial dataset conflicts the most with the other datasets,

1940 and Partitioned Bremer Support analyses identify the nodes where this conflict exists. This

1941 demonstrates that different anatomical modules (e.g., cranium, carapace) may be evolving at

1942 different rates because they are under different selective pressures (Simpson, 1950).

1943 It had been suggested by previous studies that adding more non-osteoderm character data

1944 would stabilize weakly supported and labile relationships outside of the Typothoracinae and

1945 Desmatosuchini (Desojo, 2005; Desojo, Ezcurra \& Kischlat, 2012; Roberto-da-Silva et al., 2014;

1946 Heckert et al., 2015), but doubling the size of the matrix and increasing the number of 
1947 endoskeletal characters to be dominant did not create more support, these inner tree relationships

1948 still remain weakly supported, and there is little confidence in the recovered clades. It is

1949 presently unclear how stable these nodes will be. Lack of support and accuracy could be caused

1950 by the need for more taxon sampling or by large amounts of missing data (Wiens, 1998b; Heath,

1951 Hedtke \& Hillis, 2008), but it is also possible that it is caused by incongruence between and

1952 within character suites (Lambkin et al., 2002). Moreover, missing or inapplicable data has been

1953 argued to cause ambiguous character optimizations at nodes (Ezcurra, Scheyer \& Butler, 2014).

1954 Using the total evidence approach of Kluge (1989) and adding more solid character data

1955 may overcome dataset noise (Barrett, Donoghue \& Sober, 1991), and this should be tested in

1956 future analyses. Furthermore, the present matrix contains little data from the appendicular

1957 skeleton, where the characters appear to be well-conserved, or what differences are apparent

1958 cannot be viewed outside of the realm of ontogenetic or sexual variation, but this should be a

1959 source of future characters where possible. Increased taxonomic sampling from future

1960 discoveries, including the potential discovery of other suchian taxa with lateral armor to serve as

1961 improved outgroup taxa, will undoubtedly help improve dataset resolution.

1962 Bull et al., (1993) argued that combining heterogeneous datasets can result in an

1963 erroneous parsimony estimates and that it is better to keep these data separate to avoid getting a

1964 single wrong answer. Data that fail statistical tests for heterogeneity should not be combined and

1965 used in analyses that assume the data to be homogeneous, because character datasets that appear

1966 to be independent may in fact be the result of two distinct histories of character change (Bull et

1967 al., 1993). However, according to those authors Hillis (1987) argued that because some character

1968 sets may be useful in resolving certain areas of the tree, all data should be combined. If

1969 incongruent datasets are combined, any underlying positive signal will be amplified and can

1970 often cancel out dataset noise (Lee, 2009).

1971 In the tree recovered in the main part of this study (Figure 7) it is encouraging that the

1972 topology 'makes sense', that is that there is nothing in the topology that would be a major

1973 surprise to an aetosaur worker, suggesting that an underlying positive signal is present. For 
1974 example, Scutarx deltatylus and Calyptosuchus wellesi, are recovered in the same clade, which is

1975 expected as several specimens of Scutarx had initially been assigned to Calyptosuchus (e.g.,

1976 Parker \& Irmis, 2005; Parker \& Martz, 2011; Martz et al., 2013). Stenomyti huangae and

1977 Aetosaurus ferratus are recovered close together just outside of Typothoracinae (Figure 7) and

1978 therefore presents a proposed relationship with little statistical support, yet when originally

1979 discovered the material of Stenomyti was originally assigned to Aetosaurus (Small, 1998) and

1980 utilizing only anatomical comparisons it would be expected for the two to be recovered close

1981 together, again suggesting an underlying positive signal. In contrast, the tree presented by Parker

1982 (2007) introduced two strong clades (Typothoracinae, Desmatosuchinae), but generally the

1983 overall recovered topology did not 'make sense' in regards that, 1) no terminal taxa stemmed

1984 from the base of the tree (i.e. there is no 'basal' species-group taxon), and 2) outside of the two

1985 clades, all of the other taxa were an unresolved polytomy unsupported by synapomorphies other

1986 than a few armor characters.

1987 Nonetheless, caution is warranted when equating 'sense' with accuracy as a specific tree

1988 cannot be preferred simply because it meets preconceived notions. For example, at one time it

1989 was thought that taxa with a radial ornamentation on the paramedian osteoderms, and similar

1990 lateral osteoderm anatomy formed a widely inclusive clade (Aetosaurinae, Parker, 2007), or a

1991 genus-group taxon (Stagonolepis sensu Heckert \& Lucas, 2000) and the tree presented by Parker

1992 (2007) supported the hypotheses to some extent. However, these hypotheses were quickly

1993 undermined when new cranial data were added indicating that these osteoderm characters are

1994 potentially homoplastic (Parker, 2008b; Desojo, Ezcurra \& Kischlat, 2012). Indeed, in the

1995 partition analyses presented here those clades are not recovered in the endoskeletal analyses

1996 (Figures 3c, d) and therefore are based almost entirely on osteoderm characters. Moreover, the

1997 full analysis shows that the main character combining these taxa (radial ornamentation of the 1998 paramedian osteoderms) is simply a plesiomorphic character of non-desmatosuchins. Thus, these 1999 data strongly suggest that even in a tree with much 'noise' (conflicting character data, weak 
2000 clade support) a well-supported phylogenetic signal is coming through when all of the data are 2001 combined (Baker \& DeSalle, 1997).

2002

2003 Prospectus

2004 Many of the discussions of dataset partitioning and character congruence and the 2005 strategies devised to deal with problems are from studies where morphological and molecular 2006 data are being combined (e.g., Bull et al., 1993; Huelsenbeck, Bull \& Cunningham, 1996;

2007 Cunningham, 1997; DeSalle \& Brower, 1997; Wiens, 1998a, but see Mounce, 2013). However, 2008 there is no reason not to suspect that the same phenomena may occur in studies using purely 2009 morphological data. Different anatomical modules may possess different histories and thus 2010 present conflicting character data that can mask true phylogenetic relationships or support false 2011 ones (Desojo, 2005; Parker, 2014). Workers conducting phylogenetic analyses of morphological 2012 datasets are encouraged to explore the possibilities of incongruent subsets in their data.

2013 Furthermore, ontogenetic change in aetosaurians is still poorly understood and it is 2014 important that specimens scored are at the same relative ontogenetic stage to rule out the 2015 possibility of differences caused by developmental history (Taborda, Heckert \& Desojo, 2015). 2016 Determination of maturity indicators can identify synonymous taxa (originally scored separately) 2017 and provide a baseline for morphological equivalence of taxa (or specimens) used in 2018 phylogenetic studies (Brochu, 1996). Presently the most often used indicator for pseudosuchians, 2019 including aetosaurians) is the progression of neurocentral suture closure in the vertebral column 2020 (Brochu, 1996). In aetosaurians this progression begins in the caudal series and ends with the 2021 axis/atlas (Irmis, 2007). Unfortunately, most aetosaurian specimens lack relatively complete 2022 series (e.g., Tecovasuchus chatterjeei, TTU P-545) or completely lack preserved vertebrae (e.g., 2023 Paratypothorax andressorum, SMNS unnumbered). In others, the vertebral column is covered by 2024 the articulated carapace (Coahomasuchus kahleorum, NMMNH P-18496). Fortunately, other 2025 methods such as CT scanning and histological sectioning are available, but to date only a handful 
2026 of specimens have been sampled and only two of these are holotypes (e.g., Parker, Stocker \& 2027 Irmis, 2008; Cerda \& Desojo, 2011). Aetosaur workers are encouraged to carefully determine 2028 and document maturity indicators for as many specimens as possible with a future goal of 2029 incorporating this information into phylogenetic analyses (Taborda, Heckert \& Desojo, 2015). 2030 As with any scientific study, this is a work in progress. Unfortunately, it is presently 2031 unclear whether phylogenetic relationships resulting from a matrix with an abundance of 2032 osteoderm characters (e.g., Parker, 2007) are any more correct (accurate) than those formed by a 2033 matrix with an abundance of endoskeletal (non-osteoderm) characters (this study), although I 2034 have given my reasons above for preferring the latter. This study has attempted to carefully 2035 reexamine all characters used in past analyses and to construct unambiguous characters and 2036 states. Characters were scored as carefully as possible, but certainly errors exist. The Partitioned 2037 Bremer Support analysis shows where character support for individual nodes is weak or 2038 conflicting for suites of characters and therefore can be used to examine node stability when new 2039 data are added (Gatesy et al., 2003; Wahlberg \& Nylin, 2003; Lambkin, 2004). Thus, future 2040 analyses should look to increase the number of informative characters, fill in blanks caused by 2041 missing data and correct erroneous scorings to improve accuracy and clade support. However, 2042 they should avoid adding large numbers of poorly supported characters (i.e. heavy on missing 2043 data) just for the sake of increasing characters numbers and instead focus on creating characters 2044 that can be fully or nearly fully coded to avoid decreasing overall accuracy (Wiens, 1998b). 2045

2046 2047 2048 2049 2050 2051 2052

\section{ACKNOWLEDGEMENTS}

Much of this manuscript was originally submitted for the partial requirements for the Doctor of Philosophy Degree in Geology from the University of Texas at Austin. Constructive comments on this earlier version were provided by Sterling Nesbitt, Hans Dieter-Sues, Christopher Bell, Timothy Rowe, and Julia Clarke. Access to specimens under their care was provided by T. Scott Williams and Matt Smith (PEFO); Pat Holroyd, Mark Goodwin, and Kevin Padian (UCMP); David and Janet Gillette (MNA); Julia Desojo (MACN); Jaime Powell (PVL); 
2053 Ricardo Martinez (PVSJ); Sandra Chapman, Lorna Steel, and David Gower (NHMUK); Lindsay 2054 Zanno and Vince Schneider (NCSM); Sankar Chatterjee and Bill Mueller (TTUP); Matthew 2055 Carrano (USNM); Tony Fiorillo and Ron Tykoski (DMNH); Alex Downs (GR); Charles Dailey 2056 and Dick Hilton (Sierra College); Tim Rowe, Lyndon Murray, Matt Brown, and Chris Sagebiel 2057 (UT VPL). Permission to include and discuss certain unpublished specimens was provided by 2058 Jeffrey Martz, Axel Hungerbühler, Rainer Schoch, Julia Desojo, and Tomajz Sulej. Photographs 2059 of specimens were provided by Sterling Nesbitt, Julia Desojo, Jeff Wilson, Jeff Martz, Randy 2060 Irmis, and Richard Butler. Ben Creisler graciously formulated the new taxonomic name for the 2061 Petrified Forest aetosaur. Other taxonomic advice was provided by Christian Kammerer. 2062 Thorough reviews by Roland Sookias, Julia Desojo, and Andrew Farke improved the final 2063 manuscript. This is Petrified Forest National Park Paleontological Contribution 36.

\section{REFERENCES}

2067 Adams EN. 1972. Consensus techniques and the comparison of taxonomic trees. Systematic 2068 Zoology 21:390-397.

Agassiz L. 1844. Monographie des poissons fossiles du Vieux Grés Rouge ou Système Dévonien (Old Red Sandstone) des Îles Britanniques et de Russie. Neuchâtel: Jent et Gassman.

Antczak M. 2015. Late Triassic aetosaur (Archosauria) from Krasiejów (SW Poland): new 2072 species or example of individual variation? Geological Journal. Published online in Wiley Online Library. DOI: 10.1002/gj.2691.

Baker RH, DeSalle R. 1997. Multiple sources of character information and the phylogeny of Hawaiian dropsophilids. Systematic Biology 46:654-673. 
2076 Baker RH, Yu X, DeSalle R. 1998. Assessing the relative contribution of molecular and 2077 morphological characters in simultaneous analysis trees. Molecular Phylogenetics and $2078 \quad$ Evolution 9:427-436.

2079 Barrett M, Donoghue MJ, Sober E. 1991. Against consensus. Systematic Zoology 40:486-493. 2080 Bonaparte JF. 1969. Dos nuevas "faunas" de reptiles Triásicos de Argentina. In: Amos AJ, ed. 2081 Gondwana Stratigraphy, IUGS Symposium, Buenos Aires, 1-15 October 1967. Paris: 2082 2083 2084 2085 2086 2087 2088 United Nations Educational Scientific and Cultural Organization. 283-306

Bonaparte JF. 1972 [imprint 1971]. Los tetrápodos del sector superior de la Formación Los Colorados, La Rioja, Argentina (Triásico Superior). I Parte. Opera Lilloana 22:1-183.

Brady LF. 1958. New occurrence of Desmatosuchus in Northern Arizona. Plateau 30:61-63.

Brochu CA. 1996. Closure of neurocentral sutures during crocodilian ontogeny: implications for maturity assessment in fossil archosaurs. Journal of Vertebrate Paleontology 16:49-62.

Brower AVZ. 2006. The how and why of branch support and partioned branch support, with a new index to assess partition incongruence. Cladistics 22:378-386.

Bull JJ, Huelsenbeck JP, Cunningham CW, Swofford DL, Waddell PJ. 1993. Partitioning and combining data in phylogenetic analysis. Systematic Biology 42:384-397.

Butler RJ, Sullivan C, Ezcurra MD, Liu J, Lecuona A, Sookias RB. 2014. New clade of enigmatic early archosaurs yields insights into early pseudosuchian phylogeny and the biogeography of the archosaurs radiation. BMC Evolutionary Biology 14:128. doi:10.1186/1471-2148-14-128

Camp CL. 1930. A study of the phytosaurs with description of new material from Western North America. Memoirs of the University of California 10:1-174.

2099 Casamiquela RM. 1960. Noticia preliminar sobre dos nuevos estagonolepoideos 
Argentinos. Ameghiniana 2:3-9.

2101 Casamiquela RM. 1961. Dos nuevos estagonolepoideos Argentinos (de Ischigualasto, San Juan).

2102 Revista de la Asociación Geológica de Argentina 16:143-203.

2103 Casamiquela RM. 1967. Materiales adicionales y reinterpretación de Aetosauroides scagliai (de

2104 Ischigualasto, San Juan). Revista del Museo de La Plata (nueva serie), Tomo 5, Sección

$2105 \quad$ Paleontología 33:173-196.

2106 Casamiquela RM. 1980. Nota sobre restos de un reptile aetosauroideo (Thecodontia, Aetosauria)

2107 de Quimal, Cordillera de Domeyko, Antofagasta. Prueba de la existencia del Neotriásico

2108 continental en los Andes del Norte de Chile. In: Actas del Segundo Congreso Argentino

2109 de Paleontología y Bioestratigrafía y Primer Congreso Latinoamericano de

2110 Paleontología, Buenos Aires, Argentina, 2-6 de Abril, 1978, Volume 1. Buenos Aires:

$2111 \quad$ Asociación Paleontológica Argentina. 135-142

2112 Case EC. 1920. Preliminary description of a new suborder of phytosaurian reptiles with a

2113 description of a new species of Phytosaurus. Journal of Geology 28:524-535.

2114 Case EC. 1922. New reptiles and stegocephalians from the Upper Triassic of western Texas.

2115 Carnegie Institution of Washington Publication 321:1-84.

2116 Case EC. 1929. Description of the skull of a new form of phytosaur with notes on the characters

2117 of described North American phytosaurs. Memoirs of the University of Michigan

2118 Museums, Museum of Paleontology 2:1-56.

2119 Case EC. 1932. A perfectly preserved segment of the armor of a phytosaur, with associated

$2120 \quad$ vertebrae. Contributions from the Museum of Paleontology, University of Michigan 4:57-

212180. 
2122 Cerda IA, Desojo JB. 2011. Dermal armour histology of aetosaurs (Archosauria: Pseudosuchia),

2123 from the Upper Triassic of Argentina and Brazil. Lethaia 44:417-428.

2124 Chatterjee S. 1985. Postosuchus, a new thecodontian reptile from the Triassic of Texas and the

2125 origin of tyrannosaurs. Philosophical Transactions of the Royal Society of London, Series

$2126 \quad B$ 309:395-460.

2127 Clarke JA, Middleton KM. 1998. Mosaicism, modules, and the evolution of birds: results from a

2128 Bayesian approach to the study of morphological evolution using discrete character data.

$2129 \quad$ Systematic Biology 57:185-201.

2130 Coddington J, Scharff N. 1994. Problems with zero-length branches. Cladistics 10:415-423.

2131 Cope ED. 1875. Report on the geology of that part of northwestern New Mexico examined

2132 during the field season of 1874. In: Wheeler GM, ed. Annual report upon the

2133 geographical explorations west of the one hundredth meridian in California, Nevada,

2134 Nebraska, Utah, Arizona, Colorado, New Mexico, Wyoming and Montana. Washington,

2135 DC: United States Government Printing Office. 981-1017 (61-97 of separate report LL).

2136 Cope ED. 1877. The extinct vertebrata obtained in New Mexico by parties of the expedition of

2137 1874. In: Wheeler GM, ed. Report upon United States geographical surveys west of the

2138 one hundredth meridian, volume 4, paleontology. Washington, DC: United States

2139 Government Printing Office. 1-36B.

2140 Cope ED. 1887. A contribution to the history of the Vertebrata of the Trias of North America.

2141 Proceedings of the American Philosophical Society 24:209-228.

2142 Cope ED. 1892. A contribution to the vertebrate paleontology of Texas. Proceedings of the

2143 American Philosophical Society 30:123-131. 
2144 Cunningham CW. 1997. Can three incongruence tests predict when data should be combined? $2145 \quad$ Molecular Biology and Evolution 14:733-740.

2146 Dalton R. 2008. Fossil reptiles mired in controversy. Nature 451:510.

2147 de Ricqlès AJ, Padian K, Horner JR. 2003. On the bone histology of some Triassic

2148 pseudosuchian archosaurs and related taxa. Annales de Paléontologie 89:67-101

2149 DeSalle R, Brower AVZ. 1997. Process partitions, congruence, and the independence of

2150 characters: inferring relationships among closely related Hawaiian Drosophilla from 2151 multiple gene regions. Systematic Biology 46:751-764.

2152 Desojo JB. 2005. Los aetosaurios (Amniota, Diapsida) de América del Sur: sus relaciones y

2153 aportes a la biogeografía y bioestratigrafía del Triásico continental. PhD thesis,

$2154 \quad$ Universidad de Buenos Aires.

2155 Desojo JB, Heckert AB. 2004. New information on the braincase and mandible of

2156 Coahomasuchus (Archosauria: Aetosauria) from the Otischalkian (Carnian) of Texas.

2157 Neues Jahrbuch für Geologie und Paläontologie, Monatshefte 2004:605-616.

2158 Desojo JB, Báez AM. 2005. El esqueleto postcraneano de Neoaetosauroides (Archosauria:

2159 Aetosauria) del Triásico Superior del centro-oeste de Argentina. Ameghiniana 42:115-

$2160 \quad 126$.

2161 Desojo JB, Báez AM. 2007. Cranial morphology of the Late Triassic South American archosaur 2162 Neoaetosauroides engaeus: evidence for aetosaurian diversity. Palaeontology 50:2672163 276.Desojo JB, Vizcaíno SF. 2009. Jaw biomechanics in the South American aetosaur 2164 Neoaetosauroides engaeus. Paläontologische Zeitschrift 83:499-510. 
2165 Desojo JB, Ezcurra MD. 2011. A reappraisal of the taxonomic status of Aetosauroides

2166 (Archosauria, Aetosauria) specimens from the Late Triassic of South America and their

2167 proposed synonymy with Stagonolepis. Journal of Vertebrate Paleontology 31:596-609.

2168 Desojo JB, Schoch RR. 2014. Cranial anatomy of the large aetosaur Paratypothorax

2169

andressorum from the Upper Triassic of Germany [Abstract]. Journal of Vertebrate

2170 Paleontology, Program and Abstracts 2014:120.

2171

Desojo JB, Ezcurra MD, Kischlat EE. 2012. A new aetosaur genus (Archosauria: Pseudosuchia)

2172 from the early Late Triassic of southern Brazil. Zootaxa 3166:1-33.

2173

Desojo JB, Heckert AB, Martz JW, Parker WG, Schoch RR, Small BJ, Sulej T. 2013.

2174

2175 Aetosauria: a clade of armoured pseudosuchians from the Upper Triassic continental beds. In: Nesbitt SJ, Desojo JB, Irmis RB, eds. Anatomy, Phylogeny, and Palaeobiology of Early Archosaurs and their Kin. Geological Society, London, Special Publications 379. Bath: The Geological Society Publishing House. 203-239.

Deutsche Stratigraphische Kommission. 2005. Stratigraphie von Deutschland IV: Keuper. Courier Forschungs-Institut Senckenberg 253:1-296.

2180 Donoghue MJ, Doyle JA, Gauthier J, Kluge AG, Rowe T. 1989. The importance of fossils in phylogeny reconstruction. Annual Review of Ecology and Systematics 20:431- 460.

Dzik J. 2001. A new Paleorhinus fauna in the early Late Triassic of Poland. Journal of Vertebrate Paleontology 21:625-627.

Dzik J, Sulej T. 2007. A review of the early Late Triassic Krasiejów biota from Silesia, Poland. Palaeontologia Polonica 64:3-27.

Efron, B, Halloran, E, Holmes, S. 1996. Bootstrap confidence levels for phylogenetic trees. Proceedings of the National Academy of Sciences of the U. S. A. 93:7085-7090. 
2188 Ezcurra MD, Scheyer TM, Butler RJ. 2014. The origin and early evolution of Sauria: reassessing 2189 the Permian saurian fossil record and the timing of crocodile-lizard divergence. $P L o S$ $2190 \quad$ ONE 9(2):e89165.

2191 Faith DP. 1991. Cladistic permutation tests for monophyly and nonmonophyly. Systematic 2192 Biology 40:366-375.

2193 Faith DP, Cranston PS. 1991. Could a cladogram this short have arisen by chance alone? On $2194 \quad$ permutation tests for cladistic structure. Cladistics 7:1-28.

2195 Farlow JO, Schachner ER, Sarrazin JC, Klein H, Currie PJ. 2014. Pedal proportions 2196 of Poposaurus gracilis: convergence and divergence in the feet of archosaurs. The $2197 \quad$ Anatomical Record 297:1022-1046.

2198 Farris JS, Källersjö M, Kluge AG, Bult C.. 1995. Testing significance of incongruence. $2199 \quad$ Cladistics 10:315-319.

2200 Fraas O. 1877. Aetosaurus ferratus, die gepanzerte Vogelechse aus dem Stubensandstein bei $2201 \quad$ Stuttgart. Jahreshefte des Vereins für vaterländische Naturkunde in Württemberg 33:1$2202 \quad 21$.

2203 Fraser NC, Heckert AB, Lucas SG, Schneider VP. 2006. The first record of Coahomasuchus 2204 (Archosauria: Stagonolepididae) from the Carnian of eastern North America [Abstract]. 2205 Journal of Vertebrate Paleontology 26 (supplement to number 3):63A.

2206 Furin S, Preto N, Rigo M, Roghi G, Gianolla P, Crowley JL, Bowring SA. 2006. High-precision 2207 $\mathrm{U}-\mathrm{Pb}$ zircon age from the Triassic of Italy: implications for the Triassic time scale and the 2208 Carnian origin of calcareous nannoplankton and dinosaurs. Geology 34:1009-1012.

2209 Gatesy J, Amato G, Norell M, DeSalle R, Hayashi C. 2003. Combined support for wholesale 2210 taxic atavism in gavialine crocodylians. Systematic Biology 52:403-433. 
2211 Gauthier JA, Kluge AG, Rowe T. 1988. Amniote phylogeny and the importance of fossils. $2212 \quad$ Cladistics 4:105-209.

2213 Gower DJ, Walker AD. 2002. New data on the braincase of the aetosaurian archosaur (Reptilia:

2214 Diapsida) Stagonolepis robertsoni Agassiz. In: Norman DB, Gower DJ, eds.

2215 Archosaurian Anatomy and Paleontology. Essays in Memory of Alick D. Walker.

2216 Zoological Journal of the Linnaean Society 136. London: The Linnaean Society of $2217 \quad$ London. 7-23.

2218 Gregory JT. 1953a. Typothorax and Desmatosuchus. Postilla 16:1-27.

2219 Gregory JT. 1953b. Typothorax scutes from Germany. Postilla 15:1-6.

2220 Gregory JT. 1962. The genera of phyosaurs. American Journal of Science 260:652-690.

2221 Gregory JT, Westphal F. 1969. Remarks on the phytosaur genera of the European Trias. Journal 2222 of Paleontology 43:1296-1298.

2223 Harris SR, Gower DJ, Wilkinson M. 2003. Intraorganismal homology, character construction, 2224 and the phylogeny of aetosaurian archosaurs (Reptilia, Diapsida). Systematic Biology $2225 \quad 52: 239-252$.

2226 Heath TA, Hedtke SM, Hillis DM. 2008. Taxon sampling and the accuracy of phylogenetic 2227 analysis. Journal of Systematics and Evolution 46:239-257.

2228 Heckert AB. 2003 [imprint 2002]. A revision of the Upper Triassic ornithischian dinosaur 2229 Revueltosaurus, with a description of a new species. In: Heckert AB, Lucas SG, eds. $2230 \quad$ Upper Triassic Stratigraphy and Paleontology. New Mexico Museum of Natural History 2231 and Science Bulletin 21. Albuquerque: New Mexico Museum of Natural History and $2232 \quad$ Science. 253-268. 
2233 Heckert AB, Lucas SG. 1998. First occurrence of Aetosaurus (Reptilia: Archosauria) in the

2234 Upper Triassic Chinle Group (USA) and its biochronological significance. Neues

2235

2236

Heckert AB, Lucas SG. 1999. A new aetosaur (Reptilia: Archosauria) from the Upper Triassic of Texas and the phylogeny of aetosaurs. Journal of Vertebrate Paleontology 19:50-68.

Heckert AB, Lucas SG. 2000. Taxonomy, phylogeny, biostratigraphy, biochronology, paleobiogeography, and evolution of the Late Triassic Aetosauria (Archosauria: Crurotarsi). Zentralblatt für Geologie und Paläontologie Teil I 1998 Heft 11-12:15391587.

Heckert AB, Lucas SG, Hunt AP, Harris JD. 2001. A giant phytosaur (Reptilia: Archosauria)

Heckert AB, Lucas SG. 2002. South American occurrences of the Adamanian (Late Triassic: latest Carnian) index taxon Stagonolepis (Archosauria: Aetosauria) and their biochronological significance. Journal of Paleontology 76:852-863.

Heckert AB, Zeigler KE. 2003. The Late Triassic Snyder Quarry: A brief history of discovery and excavation. In: Zeigler KE, Heckert AB, Lucas SG, eds. Paleontology and Geology of the Upper Triassic (Revueltian) Snyder Quarry, New Mexico. New Mexico Museum of Natural History and Science Bulletin 24. Albuquerque: New Mexico Museum of Natural History and Science. 5-13.

Heckert AB, Hunt AP, Lucas SG. 1996. Redescription of Redondasuchus reseri, a Late Triassic aetosaur (Reptilia: Archosauria) from New Mexico (U.S.A.), and the biochronology and phylogeny of aetosaurs. Geobios 29:619-632. skull from the Redonda Formation (Upper Triassic: Apachean) of east-central New Mexico. In: Lucas SG, Ulmer-Scholle DS, eds. Geology of the Llano Estacado, 52 
2256

2257

2258

2259

2260

2261

2262

2263

2264

2265

2266

2267

2268

2269

2270

2271

2272

2273

2274

2275

2276

2277

Field Conference. New Mexico Geological Society Guidebook. Socorro: New Mexico Geological Society. 169-176.

Heckert AB, Zeigler KE, Lucas SG. 2003. Aetosaurs (Archosauria: Stagonolepididae) from the Upper Triassic (Revueltian) Snyder Quarry, New Mexico. In: Zeigler KE, Heckert AB, Lucas SG, eds. Paleontology and Geology of the Upper Triassic (Revueltian) Snyder Quarry, New Mexico. New Mexico Museum of Natural History and Science Bulletin 24. Albuquerque: New Mexico Museum of Natural History and Science. 115-126.

Heckert AB, Lucas SG, Hunt AP. 2005. Triassic vertebrate fossils in Arizona. In: Heckert AB, Lucas SG, eds. Vertebrate Paleontology in Arizona. New Mexico Museum of Natural History and Science Bulletin 29. Albuquerque: New Mexico Museum of Natural History and Science. 16-44.

Heckert AB, Lucas SG, Sullivan RM, Hunt AP, Spielmann JA. 2005. The vertebrate fauna of the Upper Triassic (Revueltian: early-mid Norian) Painted Desert Member (Petrified Forest Formation: Chinle Group) in the Chama Basin, northern New Mexico. In: Lucas SG, Zeigler KE, Lueth VW, Owen DE, eds, Geology of the Chama Basin, $56^{\text {th }}$ Field Conference. New Mexico Geological Society Guidebook. Socorro: New Mexico Geological Society. 302-318.

Heckert AB, Spielmann JA, Lucas SG, Hunt AP. 2007. Biostratigraphic utility of the Upper Triassic aetosaur Tecovasuchus (Archosauria: Stagonolepididae), an index taxon of St. Johnsian (Adamanian: Late Carnian) time. In: Lucas SG, Spielmann JA, eds. The Global Triassic. New Mexico Museum of Natural History and Science Bulletin 41. Albuquerque: New Mexico Museum of Natural History and Science. 51-57. 
2278 Heckert AB, Lucas SG, Rinehart LF, Celeskey MD, Spielmann JA, Hunt AP. 2010. Articulated 2279 skeletons of the aetosaur Typothorax coccinarum Cope (Archosauria: Stagonolepididae) 2280 from the Upper Triassic Bull Canyon Formation (Revueltian: early-mid Norian), eastern 2281 New Mexico, USA. Journal of Vertebrate Paleontology 30:619-642.

2282 Heckert AB, Lucas SG, Spielmann JA. 2012. A new species of the enigmatic archosauromorph 2283 Doswellia from the Upper Triassic Bluewater Creek Formation, New Mexico, USA. 2284 Palaeontology 55:1333-1348.

2285

2286

2287 2288 2289 2290

2291

2292 2293

2294 2295 2296 2297 2298 2299

Heckert AB, Schneider VP, Fraser NC, Webb RA. 2015. A new aetosaur (Archosauria: Suchia) from the Upper Triassic Pekin Formation, Deep River Basin, North Carolina, U. S. A., and its implications for early aetosaur evolution. Journal of Vertebrate Paleontology 35:e881831.

Hill RV. 2005. Integration of morphological data sets for phylogenetic analysis of Amniota: the importance of integumentary characters and increased taxonomic sampling. Systematic Biology 54:530-547.

Hillis DM. 1987. Molecular vs. morphological approaches to systematics. Annual Review of Ecology and Systematics 18:23-42.

Hillis DM. 1998. Taxonomic sampling, phylogenetic accuracy, and investigator bias. Systematic Biology 47:3-8.

Hillis DM, Huelsenbeck JP. 1992. Signal, noise, and reliability in molecular phylogenetic analyses. Journal of Heredity 83:189-195.

Hillis DM, Bull JJ. 1993. An empirical test of bootstrapping as a method for accessing confidence in phylogenetic analysis. Systematic Biology 42:182-192. 
2300 Hillis DM, Huelsenbeck JP, Cunningham CW. 1994. Application and accuracy of molecular $2301 \quad$ phylogenies. Science 264:671-677.

2302 Huber P, Lucas SG, Hunt AP. 1993. Vertebrate biochronology of the Newark Supergroup 2303 Triassic, eastern North America. In: Lucas, SG, Morales M, eds. The Nonmarine 2304 2305 2306

Hunt AP. 1989. A new ?ornithischian dinosaur from the Bull Canyon Formation (Upper Triassic) of east-central New Mexico. In: Lucas SG, Hunt AP, eds. Dawn of the Age of Dinosaurs in the American Southwest. Albuquerque: New Mexico Museum of Natural History. 355-358.

Hunt AP. 1998. Preliminary results of the dawn of the dinosaurs project at Petrified Forest National Park, Arizona. In: Santucci VL, McClelland L, eds. National Park Service Paleontological Research. Geological Resources Division Technical Report NPS/ NRGRD/GRDTR-98/01, October, 1998. Lakewood: Geological Resources Division. 135-137.

Hunt AP. 2001. The vertebrate fauna, biostratigraphy and biochronology of the type Revueltian land-vertebrate faunachron, Bull Canyon Formation (Upper Triassic), east-central New Mexico. In: Lucas SG, Ulmer-Scholle DS, eds. Geology of the Llano Estacado, $52^{\text {nd }}$ 
2322

2323

2324

2325

2326

2327

2328

2329

2330

2331

2332

2333

2334

2335

2336

2337

2338

2339

2340

2341

2342

2343

2344

Field Conference. New Mexico Geological Society Guidebook. Socorro: New Mexico Geological Society. 123-151.

Hunt AP, Lucas SG. 1990. Re-evaluation of 'Typothorax' meadei, a Late Triassic aetosaur from the United States. Paläontologische Zeitschrift 64:317-328.

Hunt AP, Lucas SG. 1991. A new aetosaur from the Redonda Formation (Late Triassic: middle Norian) of east-central New Mexico, U.S.A. Neues Jahrbuch für Geologie und Paläontologie, Monatshefte 1991:728-736.

Hunt AP, Lucas SG. 1992. The first occurrence of the aetosaur Paratypothorax andressi (Reptilia: Archosauria) in the western United States and its biochronological significance. Paläontologische Zeitschrift 66:147-157.

Hunt AP, Lucas SG, Reser PK. 1993. A complete skeleton of the stagonolepidid Typothorax coccinarum from the Upper Triassic Bull Canyon Formation of east-central New Mexico, USA. In: Lucas SG, Morales M, eds. The Non-Marine Triassic. New Mexico Museum of Natural History and Science Bulletin 3. Albuquerque: New Mexico Museum of Natural History and Science. 209-212.

Hunt AP, Lucas SG, Heckert AB. 2005. Definition and correlation of the Lamyan: A new biochronological unit for the non-marine late Carnian (Late Triassic). In: Lucas SG, Zeigler KE, Lueth VW, Owen DE, eds. Geology of the Chama Basin, $56^{\text {th }}$ Field Conference. New Mexico Geological Society Guidebook. Socorro: New Mexico Geological Society. 357-366.

Huxley TH. 1859. On the Stagonolepis robertsoni (Agassiz) of the Elgin Sandstone; and on the recently discovered footmarks in the Sandstones of Cummingstone. Proceedings of the Geological Society 15:440-460. 
2345 Huxley TH. 1875. On Stagonolepis robertsoni, and on the evolution of the crocodylia. Quarterly $2346 \quad$ Journal of the Geological Society 31:423-438.

2347 Huxley TH. 1877. The crocodilian remains found in the Elgin sandstones, with remarks on the 2348 ichnites of Cummingstone. Memoirs of the Geological Survey of the United Kingdom $2349 \quad 3: 1-58$

2350 ICZN. 1999. International Code of Zoological Nomenclature. Fourth Edition. London: The $2351 \quad$ International Trust for Zoological Nomenclature. 306.

2352 Irmis RB. 2007. Axial skeleton ontogeny in the Parasuchia (Archosauria: Pseudosuchia) and its 2353 implications for ontogenetic determination in archosaurs. Journal of Vertebrate $2354 \quad$ Paleontology 27:350-361.

2355 Irmis RB. 2008. Perspectives on the origin and early diversification of dinosaurs. PhD thesis, $2356 \quad$ University of California, Berkeley.

2357 Irmis RB, Nesbitt SJ, Padian K, Smith ND, Turner AH, Woody D, Downs A. 2007. A Late 2358 Triassic dinosauromorph assemblage from New Mexico and the rise of dinosaurs. Science 317:358-361.

2360 Irmis RB, Martz JW, Parker WG, Nesbitt SJ. 2010. Re-evaluating the correlation between Late 2361 2362 Triassic terrestrial vertebrate biostratigraphy and the GSSP-defined marine stages.

2363 Irmis RB, Mundil R, Martz JW, Parker WG. 2011. High-resolution U-Pb ages from the Upper 2364 Triassic Chinle Formation (New Mexico, USA) support a diachronous rise of dinosaurs. 2365 Earth and Planetary Science Letters 309:258-267.

2366 Jenkins FA Jr., Shubin NH, Amaral WW, Gatesy SM, Schaff CR, Clemmensen LB, Downs WR, 2367 Davidson, AR, Bonde N, Osbæck F. 1994. Late Triassic continental vertebrates and 
depositional environments of the Fleming Fjord Formation, Jameson Land, East Greenland. Meddelelser om Grønland Geoscience 32:1-25.

2370 Kent DV, Santi Malnis P, Columbi CE, Alcober OA, Martinez RN. 2014. Age constraints on the 2371 dispersal of dinosaurs in the Late Triassic from magnetochronology of the Los Colorados

Kitching IJ, Forey PL, Humphries CJ, Williams DM. 1998. Cladistics: the Theory and Practice 2375 of Parsimony Analysis, $2^{\text {nd }}$ edition. The Systematics Association Publication 11. Oxford:

Kluge AG. 1989. A concern for evidence and a phylogenetic hypothesis of relationships among Oxford University Press.

Lambkin CL. 2004. Partitioned Bremer support localizes significant conflict in bee flies (Diptera: Bombyliidae: Anthracinae). Invertebrate Systematics 18:351-360. multiple trees. Cladistics 18:436-444.

Landry, SO. 1958. The function of the entepicondylar foramen in mammals. American Midland 2384 Naturalist 60:100-112.

Langer MC, Ribeiro AM, Schultz CL Ferigolo J. 2007. The continental tetrapod-bearing Triassic of South Brazil. In: Lucas SG, Spielmann JA, eds. The Global Triassic. New Mexico Museum of Natural History and Science Bulletin 41. Albuquerque: New Mexico Museum of Natural History and Science. 201-218.

Lee MSY. 2001. Uninformative characters and apparent conflict between molecules and morphology. Molecular Biology and Evolution 18:676-680. 
2391 Lee MSY. 2009. Hidden support from unpromising data sets strongly unites snakes with 2392 anguimorph 'lizards.' Journal of Evolutionary Biology 22:1308-1316.

2393 Lichtig AJ, Lucas SG. 2014. New reconstruction of the Late Triassic aetosaur Rioarribasuchus 2394 chamaensis from the Snyder Quarry, Chama Basin, north-central New Mexico, USA 2395

Long RA, Murry PA. 1995. Late Triassic (Carnian and Norian) tetrapods from the southwestern United States. New Mexico Museum of Natural History and Science Bulletin 4:1-254.

Lucas SG. 1998a. Global Triassic tetrapod biostratigraphy and biochronology. Palaeogeography, Palaeoclimatology, Palaeoecology 143:347-384.

Lucas SG. 1998b. The aetosaur Longosuchus from the Triassic of Morocco and its biochronological significance. Comptes rendus de l'Académie des science Série II, sciences de la terre et des planètes 326:589-594.

Lucas SG. 2000. Pathological aetosaur armor from the Upper Triassic of Germany. Stuttgarter Beiträge zur Naturkunde Serie B (Geologie und Paläontologie) 281:1-6.

2411 Lucas SG. 2010. The Triassic timescale based on nonmarine tetrapod biostratigraphy and biochronology. In: Lucas SG, ed. The Triassic Timescale. Geological Society, London, Special Publications 334. Bath: The Geological Society Publishing House. 447-500. 
2414 Lucas SG, Heckert AB. 1996. Vertebrate biochronology of the Late Triassic of Arizona. In Boaz

2415 D, Dierking P, Dornan M, McGeorge R, Tegowski BJ, eds. Proceedings of the Fossils of 2416 Arizona Symposium Volume 4. Mesa: Mesa Southwest Museum Bulletin and the City of 2417 Mesa. 63-81.

2418 Lucas SG, Heckert AB. 2001. The aetosaur Stagonolepis from the Upper Triassic of Brazil and 2419 its biochronological significance. Neues Jahrbuch für Geologie und Paläontologie, $2420 \quad$ Monatshefte 2001:719-732.

2421 Lucas SG, Connealy S. 2008. Triassic New Mexico: Dawn of the Dinosaurs. Albuquerque: New $2422 \quad$ Mexico Museum of Natural History and Science. 48.

2423 Lucas SG, Hunt AP, Kahle R. 1993. Late Triassic vertebrates from the Dockum Formation near 2424

2425

2426

2427

2428

2429

2430

2431 Otis Chalk, Howard County, Texas. In: Love DW, Hawley JW, Kues BS, Adams JW, Austin GS, Barker JM, eds. Carlsbad Region, New Mexico and West Texas, 44th Field Conference. Albuquerque: New Mexico Geological Society. 237-244.

Lucas SG, Heckert AB, Hunt AP. 1995. Unusual aetosaur armor from the Upper Triassic of west Texas. Paläontologische Zeitschrift 69:467-473.

Lucas SG, Heckert AB, Huber P. 1998. Aetosaurus (Archosauromorpha) from the Upper Triassic of the Newark Supergroup, eastern United States, and its biochronological significance. Palaeontology 41:1215-1230.

2432 Lucas SG, Heckert AB, Hunt AP. 2003 [imprint 2002]. A new species of the aetosaur 2433 Typothorax (Archosauria: Stagonolepididae) from the Upper Triassic of east-central New Mexico. In: Heckert AB, Lucas SG, eds. Upper Triassic Stratigraphy and Paleontology. New Mexico Museum of Natural History and Science Bulletin 21. Albuquerque: New Mexico Museum of Natural History and Science. 221-233. 
2437 Lucas SG, Zeigler KE, Heckert AB, Hunt AP. 2005. Review of Upper Triassic stratigraphy and

2438 biostratigraphy in the Chama Basin, northern New Mexico. In: Lucas SG, Zeigler KE,

2439 Lueth VW, Owen DE, eds. Geology of the Chama Basin, $56^{\text {th }}$ Field Conference. Socorro:

$2440 \quad$ New Mexico Geological Society. 170-181.

2441 Lucas SG, Hunt AP, Spielmann JA. 2006. Rioarribasuchus, a new name for an aetosaur from the

2442 Upper Triassic of north-central New Mexico. In: Harris JD, Lucas SG, Spielmann JA,

2443 Lockley MG, Milner ARC, Kirkland JI, eds. The Triassic-Jurassic Terrestrial Transition.

2444 New Mexico Museum of Natural History and Science Bulletin 37. Albuquerque: New

2445 Mexico Museum of Natural History and Science. 581-582.

2446 Lucas SG, Heckert AB, Rinehart LF. 2006. The Late Triassic aetosaur Paratypothorax; In:

2447 Harris JD, Lucas SG, Spielmann JA, Lockley MG, Milner ARC, Kirkland JI, eds. The

2448 Triassic-Jurassic Terrestrial Transition. New Mexico Museum of Natural History and

2449 Science Bulletin 37. Albuquerque: New Mexico Museum of Natural History and Science.

$2450 \quad 575-580$.

2451 Lucas SG, Hunt, AP, Spielmann JA. 2007. A new aetosaur from the Upper Triassic (Adamanian:

2452 Carnian) of Arizona. In: Lucas SG, Spielmann JA, eds. Triassic of the American West.

2453 New Mexico Museum of Natural History and Science Bulletin 40. Albuquerque: New

2454 Mexico Museum of Natural History and Science. 241-247.

2455 Lucas SG, Spielmann JA, Hunt AP. 2007. Biochronological significance of Late Triassic

2456 tetrapods from Krasiejów, Poland. In: Lucas SG, Spielmann JA, eds. The Global Triassic.

2457 New Mexico Museum of Natural History and Science Bulletin 41. Albuquerque: New

2458 Mexico Museum of Natural History and Science. 248-258. 
2459 Maddison WP, Maddison DR. 2011. Mesquite: a modular system for evolutionary analysis.

2460 Version 2.75. http://mesquiteproject.org.

2461 Main RP, de Ricqlès A, Horner JR, Padian K. 2005. The evolution and function of thyreophoran 2462 dinosaur scutes: implications for plate function in stegosaurs. Paleobiology 31:291-314.

2463 Martinez RN, Sereno PC, Alcober OA, Colombi CE, Renne PR, Montañez IP, Currie BS. 2011.

2464 A basal dinosaur from the dawn of the dinosaur era in southwestern Pangaea. Science $2465 \quad 331: 206-210$.

2466 Martinez RN, Apaldetti, Alcober OA, Columbi CE, Sereno PE, Fernandez E, Santi Malnis P, 2467 Correa GA, Abelin D. 2013 [imprint 2012]. Vertebrate succession in the Ischigualasto

2468 Formation. In: Sereno PC, ed. Basal Sauropodomorphs and the Vertebrate Fossil Record 2469 of the Ischigualasto Formation (Late Triassic: Carnian-Norian) of Argentina. Society of 2470 Vertebrate Paleontology Memoir 12. Journal of Vertebrate Paleontology 32 (supplement to number 6), November 2012. 10-30.

2472 Martz JW. 2002. The morphology and ontogeny of Typothorax coccinarum (Archosauria, Stagonolepididae) from the Upper Triassic of the American Southwest. MS thesis, Texas:

Martz JW. 2008. Lithostratigraphy, chemostratigraphy, and vertebrate biostratigraphy of the Dockum Group (Upper Triassic), of southern Garza County, West Texas. PhD thesis. Texas: Texas Tech University, Lubbock. 504.

Martz JW, Small BJ. 2006. Tecovasuchus chatterjeei, a new aetosaur (Archosauria: Aetosauria) from the Tecovas Formation (Upper Triassic, Carnian) of Texas. Journal of Vertebrate Paleontology 26:308-320. 
2481 Martz JW, Mueller B, Nesbitt SJ, Stocker MR, Parker WG, Atanassov M, Fraser N, Weinbaum

2482 J, Lehane JR. 2013. A taxonomic and biostratigraphic re-evaluation of the Post Quarry

2483 vertebrate assemblage from the Cooper Canyon Formation (Dockum Group, Upper

2484 Triassic) of southern Garza County, western Texas. In: Parker W, Bell C, Brochu C,

2485 Irmis R, Jass C, Stocker M, Benton M, eds. The Full Profession: A Celebration of the

2486 Life and Career of Wann Langston Jr., Quintessential Vertebrate Paleontologist. Earth

2487 and Environmental Science Transactions of the Royal Society of Edinburgh 103. 339-

$2488 \quad 364$.

2489 Meyer Hv. 1861. Reptilien aus dem Stubensandstein des oberen Keupers. Palaeontographica

$2490 \quad 7: 253-351$.

2491 Meyer Hv.1865. Reptilien aus dem Stubensandstein des oberen Keupers. Palaeontographica

$2492 \quad 14: 99-124$.

2493 Mounce RCP. 2013. Comparative cladistics: fossils, morphological data partitions and lost

2494 branches in the fossil tree of life. $\mathrm{PhD}$ thesis, England: University of Bath. 161.

2495 Murry PA, Long RA. 1989. Geology and paleontology of the Chinle Formation, Petrified Forest

2496 National Park and vicinity, Arizona and a discussion of vertebrate fossils of the

2497 southwestern Upper Triassic. In: Lucas SG, Hunt AP, eds. Dawn of the Age of Dinosaurs

2498 in the American Southwest. Albuquerque: New Mexico Museum of Natural History. 29-

249964.

2500 Murry PA, Long RA. 1996. A diminutive carnivorous aetosaur from the Upper Triassic of

2501 Howard County, Texas [Abstract]. Journal of Vertebrate Paleontology 16 (supplement to

2502 number 3):55A. 
2503 Nesbitt SJ. 2011. The early evolution of archosaurs: relationships and the origin of major clades. 2504 Bulletin of the American Museum of Natural History 352:1-292.

2505 Nesbitt SJ, Butler RJ. 2013. Redescription of the archosaur Parringtonia gracilis from the 2506 Middle Triassic Manda Beds of Tanzania, and the antiquity of Erpetosuchidae. 2507 Geological Magazine 150:225-238.

2508 O'Leary MA., Kaufman SG. 2012. MorphoBank 3.0: Web application for morphological 2509 phylogenetics and taxonomy. http://www.morphobank.org.

2510 Padian K. 1990. The ornithischian form genus Revueltosaurus from the Petrified Forest of 2511 Arizona (Late Triassic, Norian; Chinle Formation). Journal of Vertebrate Paleontology $2512 \quad 10: 268-269$.

2513 Page RDM. 2001. Nexus Data Editor for Windows (NDE), version 0.5.0. Program and 2514 documentation. Available online at 2515 http://taxonomy.zoology.gla.ac.uk/rod/NDE/nde.html. Published by the author, Glasgow, $2516 \quad$ U.K.

2517 Parker WG. 2002 [imprint 2001]. An enigmatic aetosaur specimen from the Upper Triassic 2518 Dockum Formation of Texas [Abstract]. In McCord RD, Boaz D, eds. Western

Parker WG. 2003. Description of a new specimen of Desmatosuchus haplocerus from the Late 2525 Triassic of northern Arizona. MS thesis. Arizona: Northern Arizona University, Flagstaff. 315. 
2526 Parker WG. 2005a. Faunal review of the Upper Triassic Chinle Formation of Arizona. In:

2527 McCord RD, ed. Vertebrate Paleontology of Arizona. Mesa Southwest Museum Bulletin

2528 11. Mesa: Southwest Paleontological Society, Mesa Southwest Museum and the City of

$2529 \quad$ Mesa. 34-54.

2530 Parker WG. 2005b. A new species of the Late Triassic aetosaur Desmatosuchus (Archosauria:

$2531 \quad$ Pseudosuchia). Compte Rendus Paleovol 4:327-340.

2532 Parker WG. 2006. The stratigraphic distribution of major fossil localities in Petrified Forest

2533 National Park, Arizona. In: Parker WG, Ash SR, Irmis RB, eds. A Century of Research at

$2534 \quad$ Petrified Forest National Park 1906-2006: Geology and Paleontology. Museum of

2535 Northern Arizona Bulletin 62. Holbrook: Petrified Forest Museum Association. 46-62.

2536 Parker WG. 2007. Reassessment of the aetosaur "Desmatosuchus" chamaensis with a reanalysis

2537 of the phylogeny of the Aetosauria (Archosauria: Pseudosuchia). Journal of Systematic

$2538 \quad$ Palaeontology 5:1-28.

2539 Parker WG. 2008a. How many valid aetosaur species are there? Reviewing the alpha-taxonomy

2540 of the Aetosauria (Archosauria: Pseudosuchia) and its implications for Late Triassic

2541 global biostratigraphy [Abstract]. Journal of Vertebrate Paleontology 28 (supplement to

2542 number 3):125A.

2543 Parker WG. 2008b. Description of new material of the aetosaur Desmatosuchus spurensis

2544 (Archosauria: Suchia) from the Chinle Formation of Arizona and a revision of the genus

2545 Desmatosuchus. PaleoBios new series 28:1-40.

2546 Parker WG. 2013. Redescription and taxonomic status of specimens of Episcoposaurus and

2547 Typothorax, the earliest known aetosaurs (Archosauria: Suchia) from the Upper Triassic

2548 of western North America, and the problem of proxy 'holotypes'. In: Parker W, Bell C, 
2549

2550

2551

2552

2553

2554

2555

2556

2557

2558

2559

2560

2561

2562

2563

2564

2565

2566

2567

2568

2569

2570

2571

Brochu C, Irmis R, Jass C, Stocker M, Benton M, eds. The Full Profession: A Celebration of the Life and Career of Wann Langston Jr., Quintessential Vertebrate Paleontologist. Earth and Environmental Science Transactions of the Royal Society of Edinburgh 103. 313-338.

Parker WG. 2014. Taxonomy and phylogeny of the Aetosauria (Archosauria: Pseudosuchia) including a new species from the Upper Triassic of Arizona. PhD thesis. Texas: The University of Texas at Austin. 437.

Parker WG, Irmis RB. 2005. Advances in Late Triassic vertebrate paleontology based on material from Petrified Forest National Park, Arizona. In: Heckert AB, Lucas SG, eds. Vertebrate Paleontology in Arizona. New Mexico Museum of Natural History and Science Bulletin 29. Albuquerque: New Mexico Museum of Natural History and Science. $45-58$.

Parker WG, Martz JW. 2010. Using positional homology in aetosaur (Archosauria: Pseudosuchia) osteoderms to evaluate the taxonomic status of Lucasuchus hunti. Journal of Vertebrate Paleontology 30:1100-1104.

Parker WG, Martz JW. 2011. The Late Triassic (Norian) Adamanian-Revueltian tetrapod faunal transition in the Chinle Formation of Petrified Forest National Park, Arizona. In Butler RJ, Irmis RB, Langer MC, Smith AB, eds. Late Triassic Terrestrial Biotas and the Rise of Dinosaurs. Earth and Environmental Science Transactions of the Royal Society of Edinburgh 101 (for 2010). 231-260.

Parker WG, Stocker MR, Irmis RB. 2008. A new desmatosuchine aetosaur (Archosauria: Suchia) from the Upper Triassic Tecovas Formation (Dockum Group) of Texas. Journal of Vertebrate Paleontology 28:692-701. 
2572 Parker WG, Irmis RB, Nesbitt SJ, Martz JW, Browne LS. 2005. The Late Triassic pseudosuchian 2573 Revueltosaurus callenderi and its implications for the diversity of early ornithischians 2574 dinosaurs. Proceedings of the Royal Society, Series B 272:963-969.

2575 Parker WG, Brown MB, Nesbitt SJ, Stocker MR, Irmis RB. 2007. Revised osteology of 2576 Revueltosaurus callenderi (Archosauria: Pseudosuchia) based on new material from 2577 Petrified Forest National Park, Arizona [Abstract]. Journal of Vertebrate Paleontology 27 2578 (supplement to number 3):127A.

2579 Parrish JM. 1994. Cranial osteology of Longosuchus meadei and the phylogeny and distribution 2580 of the Aetosauria. Journal of Vertebrate Paleontology 14:196-209.

2581 Rae TC. 1999. Mosaic evolution in the origin of the Hominoidea. Folia Primatologia 70:1252582135.

2583 Ramezani J, Hoke GD, Fastovsky DE, Bowring SA, Therrien F, Dworkin SI, Atchley SC, Nordt 2584 LC. 2011. High-precision U-Pb zircon geochronology of the Late Triassic Chinle 2585 Formation, Petrified Forest National Park (Arizona, USA): temporal constraints on the 2586 early evolution of dinosaurs. Geological Society of America Bulletin 123:2142-2159.

2587 Ramezani J, Fastovsky DE, Bowring SA. 2014. Revised chronostratigraphy of the lower Chinle 2588 Formation strata in Arizona and New Mexico (USA): high-precision U-Pb 2589 geochronological constraints on the Late Triassic evolution of dinosaurs. American $2590 \quad$ Journal of Science 314:981-1008.

2591 Roberto-Da-Silva L, Desojo JB, Cabriera SF, Aires ASS, Müller ST, Pacheco CP, Dias-Da-Silva 2592 S. 2014. A new aetosaur from the Upper Triassic of the Santa Maria Formation, southern $2593 \quad$ Brazil. Zootaxa 3764:240-278. 
2594 Rogers RR, Swisher III CC, Sereno PC, Monetta AM, Forster CA, Martinez RN. 1993. The 2595 Ischigualasto Tetrapod Assemblage (Late Triassic, Argentina) and ${ }^{40} \mathrm{Ar} /{ }^{39} \mathrm{Ar}$ dating of 2596 dinosaur origins. Science 260:794-797.

2597 Romer AS. 1956. Osteology of the Reptiles. Chicago: University of Chicago Press. 772.

2598 Rowe T. 1988. Definition, diagnosis, and the origin of Mammalia. Journal of Vertebrate $2599 \quad$ Paleontology 8:241-264.

2600 Sawin HJ. 1947. The pseudosuchian reptile Typothorax meadei. Journal of Paleontology $2601 \quad 21: 201-238$.

2602 Scheyer TM, Desojo JB, Cerda IA. 2013. Bone histology of phytosaur, aetosaur, and other 2603 2604 archosauriform osteoderms (Eureptilia: Archosauromorpha). The Anatomical Record 297:240-260.

2605 Schneider VP, Heckert AB, Fraser NC. 2011. Diversity of aetosaurs (Archosauria: Stagonolepididae) in the Upper Triassic Pekin Formation (Deep River Basin), North Vegas, Nevada, USA November 2-5, 2011. 188.

Schoch RR. 2007. Osteology of the small archosaur Aetosaurus from the Upper Triassic of 2611 Germany. Neues Jahrbuch für Geologie und Paläontologie, Abhandlungen 246:1-35.

2612 Seidel MR. 1979. The osteoderms of the American Alligator and their functional significance. 2613 Herpetologica 35:375-380.

2614 Sereno PC. 1985. The logical basis of phylogenetic taxonomy. Systematic Biology 54:595-619.

2615 Simpson GG. 1950. The Meaning of Evolution: A study of the History of Life and of Its

2616 Significance for Man. New Haven: Yale University Press. 363. 
2617 Slowinski J. 1993. “Unordered”, versus “'ordered”' characters. Systematic Biology 42:155-165.

2618 Small BJ. 1985. The Triassic thecodontian reptile Desmatosuchus: osteology and relationships.

2619 MS thesis. Texas Texas Tech University, Lubbock. 83.

2620 Small BJ. 1989. Aetosaurs from the Upper Triassic Dockum Formation, Post Quarry, West

2621 Texas. In: Lucas SG, Hunt AP, eds. Dawn of the Age of Dinosaurs in the American

2622 Southwest, Albuquerque: New Mexico Museum of Natural History. 301-308.

2623 Small BJ. 1998. The occurrence of Aetosaurus in the Chinle Formation (Late Triassic, USA) and

2624 its biostratigraphic significance. Neues Jahrbuch für Geologie und Paläontologie,

$2625 \quad$ Monatshefte 1998:285-296.

2626 Small BJ. 2002. Cranial anatomy of Desmatosuchus haplocerus (Reptilia: Archosauria:

2627 Stagonolepididae). Zoological Journal of the Linnean Society 136:97-111.

2628 Small BJ, Martz JW. 2013. A new basal aetosaur from the Upper Triassic Chinle Formation of

2629 the Eagle Basin, Colorado, USA. In Nesbitt SJ, Desojo JB, Irmis RB, eds. Anatomy,

2630 Phylogeny and Palaeobiology of Early Archosaurs and their Kin. Geological Society,

2631 London, Special Publications 379. Bath: The Geological Society Publishing House. 393-

2632412.

2633 Sorenson MD, Franzosa EA. 2007. TreeRot, version 3. Boston University, Boston, MA.

2634 Spielmann JA, Lucas SG. 2012. Tetrapod fauna of the Upper Triassic Redonda Formation, eastcentral New Mexico: the characteristic assemblage of the Apachean land-vertebrate faunachron. New Mexico Museum of Natural History and Science Bulletin 55:1-119.

2637 Spielmann JA., Hunt AP, Lucas SG, Heckert AB. 2006. Revision of Redondasuchus

2638 (Archosauria: Aetosauria) from the Upper Triassic Redonda Formation, New Mexico, 2639 with a description of a new species. In Harris JD, Lucas SG, Spielmann JA, Lockley MG, 
2640

2641

2642

2643

2644

2645

2646

2647

2648

2649

2650

2651

2652

2653

2654

2655

2656

2657

2658

2659

2660

Milner ARC, Kirkland J.I, eds. The Triassic-Jurassic Terrestrial Transition. New Mexico Museum of Natural History and Science Bulletin 37. Albuquerque: New Mexico Museum of Natural History and Science. 583-587.

Sulej T. 2010. The skull of an early Late Triassic aetosaur and the evolution of the stagonolepidid archosaurian reptiles. Zoological Journal of the Linnean Society 158:860881.

Swofford DL. 2003. PAUP*. Phylogenetic Analysis Using Parsimony (*and Other Methods). Version 4. Sinauer Associates: Sunderland, Massachusetts.

Swofford DL, Begle DP. 1993. User manual for PAUP*, Phylogenetic Analysis Using Parsimony, version 3.1. Champaign: Illinois Natural History Survey.

Taborda JRA, Cerda IA, Desojo JB. 2013. Growth curve of Aetosauroides scagliai Casamiquela 1960 (Pseudosuchia: Aetosauria) inferred from osteoderm histology. In: Nesbitt SJ, Desojo JB, Irmis RB, eds. Anatomy, Phylogeny and Palaeobiology of Early Archosaurs and their Kin. Geological Society, London, Special Publications 379. Bath: The Geological Society Publishing House. 413-424

Taborda JRA, Heckert AB, Desojo JB. 2015. Intraspecific variation in Aetosauroides scagliai Casamiquela (Archosauria: Aetosauria) from the Upper Triassic of Argentina and Brazil: an example of sexual dimorphism? Ameghiniana 52:173-187

Vickaryous MK, Hall BK. 2008. Development of the dermal skeleton in Alligator mississippiensis (Archosauria, Crocodylia) with comments on the homology of osteoderms. Journal of Morphology 269:398-422, 
2661 Wahlberg N, Nylin S. 2003. Morphology versus molecules: resolution of the positions of 2662 Nymphalis, Polygonia, and related genera (Lepidoptera: Nymphalidae). Cladistics $2663 \quad 19: 213-223$.

2664 Walker AD. 1961. Triassic Reptiles from the Elgin Area: Stagonolepis, Dasygnathus, and their 2665 allies. Philosophical Transactions of the Royal Society of London 244:103-204.

Weinbaum JC. 2011. The skull of Postosuchus kirkpatricki (Archosauria: Paracrocodyliformes) 2667 from the Upper Triassic of the United States. PaleoBios new series 30:18-44.

Weinbaum JC. 2013. Postcranial skeleton of Postosuchus kirkpatricki (Archosauria: Paracrocodylomorpha) from the Upper Triassic of the United States. In: Nesbitt SJ, Desojo JB, Irmis RB, eds. Anatomy, Phylogeny and Palaeobiology of Early Archosaurs and their Kin. Geological Society, London, Special Publications 379. Bath: The Geological Society Publishing House. 525-553.

Wiens JJ. 1998b. Does adding characters with missing data increase or decrease phylogenetic accuracy? Systematic Biology 47:625-640.

Wild R. 1989. Aetosaurus (Reptilia: Thecodontia) from the Upper Triassic (Norian) of Cene near Bergamo, Italy, with a revision of the genus. Rivista del Museo Civico di Scienze Naturali 14:1-24.

Wiley EO, Lieberman BS. 2011. Phylogenetics: The Theory and Practice of Phylogenetic Systematics, $2^{\text {nd }}$ Edition. New Jersey: Wiley-Blackwell. 406.

2682 Wilkinson M. 1995a. Coping with abundant missing entries in phylogenetic inference using parsimony. Systematic Biology 44:501-514. 
2684 Wilkinson M. 1995b. A comparison of two methods of character construction. Cladistics 11:2972685308.

2686 Wilson JA. 1999. Vertebral laminae in sauropods and other saurischian dinosaurs. Journal of 2687 Vertebrate Paleontology 19:639-653.

2688 Zacarias JD. 1982. Uma nova espécie de tecodonte aetossauro (Aetosauroides subsulcatus, sp. 2689 nov.) da Foramação Santa Maria, Triássico de Rio Grande do Sul, Brasil. MS thesis. 2690 Brazil: Federal University of Rio Grande do Sul, Porto Alegre. 69.

2691 Zeigler KE, Heckert AB, Lucas SG. 2003 [imprint 2002]. A new species of Desmatosuchus 2692 (Archosauria: Aetosauria) from the Upper Triassic of the Chama Basin, north-central 2693 New Mexico. In Heckert AB, Lucas SG, eds. Upper Triassic Stratigraphy and 2694 Paleontology. New Mexico Museum of Natural History and Science Bulletin 21. 2695 Albuquerque: New Mexico Museum of Natural History and Science. 215-219.

2696 2697 2698 2699 2700 2701 2702 2703 2704 2705 2706 
2707

2708

2709

2710

2711

2712

2713

2714

2715

2716

2717

2718

2719

2720

2721

2722

2723

2724

2725

2726

2727

2728

2729

2730

2731

2732

Figure 1: Skeletal reconstruction of an aetosaur (Stagonolepis robertsoni) showing the extensive carapace and associated armor in dorsal (A) and lateral (B) views. Courtesy of Jeffrey Martz.

Figure 2: Holotype paramedian osteoderms of Scutarx deltatylus from PEFO 34616. A, posterior cervical osteoderm in dorsal view. B-C, right dorsal trunk paramedian osteoderm in dorsal (B) and posterior (C) views. D-E, partial right dorsal trunk paramedian osteoderm in dorsal (D) and posterior (E) views. Note the prominence of the triangular protuberance in the posterior views.

Scale bar equals $1 \mathrm{~cm}$. Abbreviations: ab, anterior bar; alp, anterolateral process; amp, anteromedial process; de, dorsal eminence; trp, triangular protuberance.

Figure 3: Holotype skull of Scutarx deltatylus (PEFO 34616) in ventral view. Scale bar equals 1 cm. Abbreviations: bpt, basipterygoid processes; bsr, basisphenoid recess; bt, basal tubera; cp, cultriform process; crp, crista prootica; f., fossa for specified element; lfr, left frontal; lr, lateral ridge; ls, laterosphenoid; of, orbital fossa; orb, orbit; par, paroccipital process of the opisthotic; po, postorbital; prf, prefrontal; pr, prootic; prf, prefrontal; psr, parasphenoid recess; quadrate; rfr, right frontal; sq, squamosal; ssr, subsellar recess; stf, supratemporal fenestra; uc, unossified cleft of the basal tubera.

Figure 4: Braincase of Scutarx deltatylus (PEFO 34616) in ventrolateral view. Scale bar equals 1 cm. Abbreviations: bpt, basipterygoid processes; bsr, basisphenoid recess; bt, basal tubera; cc, cotylar crest; clp, clinoid process; cp, cultriform process; crp, crista prootica; fo, foramen ovale; hypf, hypophyseal fossa; ic, exit area of the internal carotid artery; 1fr, left frontal; 1r, lateral ridge; 1s, laterosphenoid; mf, metotic foramen; na, nasal; oc, occipital condyle; orb, orbit; pa, 
2733 parietal; par, paroccipital process of the opisthotic; po, postorbital; pr, prootic; prf, prefrontal;

2734 psr; parasphenoid recess; rfr, right frontal; s., suture with designated element; sq, squamosal; uc,

2735 unossified cleft of the basal tubera; V, passageway for the Trigeminal nerve (CN V).

2736

2737

2738

2739

2740

2741

2742 Figure 6: Phylogenetic trees recovered from the initial run of the main dataset. A, Strict 2743

Figure 5: Right ilium of Scutarx deltatylus (PEFO 34919) in 'lateral' view (see text for discussion regarding anatomical direction of the ilium). Scale bars equal $1 \mathrm{~cm}$. Abbreviations: ac, acetabulum; isc.p, ischiadic peduncle; poab, posterior process of the iliac blade; prab, anterior process of the iliac blade; rec, recess; sac, supraacetabular crest.

component consensus of 30 MPTs; B, Adams consensus of 30 MPTs; C, 50\% Majority Rule consensus of 30 MPTs. Only values under 100\% are shown; D, Maximum agreement subtree after a priori pruning of Aetobarbakinoides brasiliensis.

Figure 7: The reduced strict consensus of 3 MPTs used for this study with Aetobarbakinoides brasiliensis removed, with all named clades. Decay indices and bootstrap values are shown for all nodes, with bootstrap values under 70\% (the confidence threshold of Hillis and Bull, 1993) shown in red.

Figure 8: Phylogenetic trees recovered from partitioning the main dataset. Decay indices and bootstrap values (1000 replicates) listed for all nodes. A, Topology of a three MPTs from the simultaneous (13 taxa, 83 characters) dataset. Partitioned Bremer Support values for nodes are given in parentheses. The first value pertains to the cranial only characters, the second from the postcranial characters, and the third from the osteoderm characters; B, Topology of a three MPTs 
2757 recovered for the osteoderm dataset; C, Strict consensus tree from two MPTs from the complete

2758 non-osteoderm (endoskeletal) dataset (cranial, axial, appendicular); D) Strict consensus of 13

2759 MPTs from analysis of the cranial dataset. 